San Jose State University

SJSU ScholarWorks

Master's Theses

Master's Theses and Graduate Research

1996

\title{
The relative impact of off-road motocycles of differing sizes on rates of mechanical erosion
}

Joseph E. Mello

San Jose State University

Follow this and additional works at: https://scholarworks.sjsu.edu/etd_theses

\section{Recommended Citation}

Mello, Joseph E., "The relative impact of off-road motocycles of differing sizes on rates of mechanical erosion" (1996). Master's Theses. 1244.

DOI: https://doi.org/10.31979/etd.3szd-9zhm

https://scholarworks.sjsu.edu/etd_theses/1244

This Thesis is brought to you for free and open access by the Master's Theses and Graduate Research at SJSU ScholarWorks. It has been accepted for inclusion in Master's Theses by an authorized administrator of SJSU ScholarWorks. For more information, please contact scholarworks@sjsu.edu. 


\section{INFORMATION TO USERS}

This manuscript has been reproduced from the microfilm master. UMI films the text directly from the original or copy submitted. Thus, some thesis and dissertation copies are in typewriter face, while others may be from any type of computer printer.

The quality of this reproduction is dependent upon the quality of the copy submitted. Broken or indistinct print, colored or poor quality illustrations and photographs, print bleedthrough, substandard margins, and improper alignment can adversely affect reproduction.

In the unlikely event that the author did not send UMI a complete manuscript and there are missing pages, these will be noted. Also, if unauthorized copyright material had to be removed, a note will indicate the deletion.

Oversize materials (e.g., maps, drawings, charts) are reproduced by sectioning the original, beginning at the upper left-hand corner and continuing from left to right in equal sections with small overlaps. Each original is also photographed in one exposure and is included in reduced form at the back of the book.

Photographs included in the original manuscript have been reproduced xerographically in this copy. Higher quality 6 " $\times 9^{\prime \prime}$ black and white photographic prints are available for any photographs or illustrations appearing in this copy for an additional charge. Contact UMI directly to order.

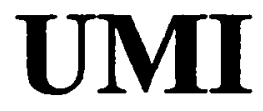

A Bell \& Howell Information Company 

THE REIATIVE IMPACT OF OFF-ROAD MOTORCYCLES

OF DIFFERIMG SIZES OA RATES OF MECHAMICAL EROSION

\author{
A Thesis \\ Presented to \\ The Faculty of the Department of Geology \\ San Jose State University
}

In Partial Fulfillment

of the Requirements for the Degree

Master of Science

by

Joseph E. Mello, Jr.

May 1996 
UMI Number: 1379359

\section{Copyright 1996 by Mello, Joseph E., Jr.}

All rights reserved.

UMI Microform 1379359

Copyright 1996, by UMI Company. All rights reserved.

This microform edition is protected against unauthorized copying under Title 17, United States Code.

\section{UMI \\ 300 North Zeeb Road \\ Ann Arbor, MI 48103}


$\odot 1996$

Joseph E. Mello, Jr.

ALI RIGHTS RESERVED 


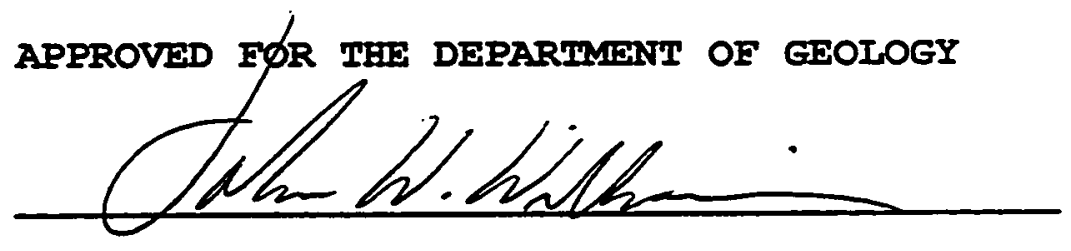

Dr. John พ. Williams

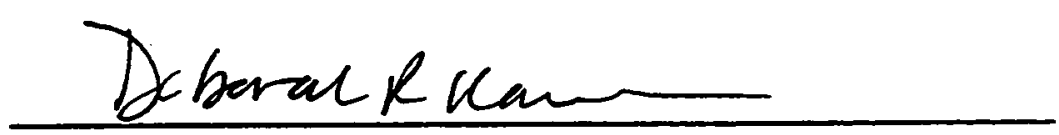

Dr. Deborah R. Harden

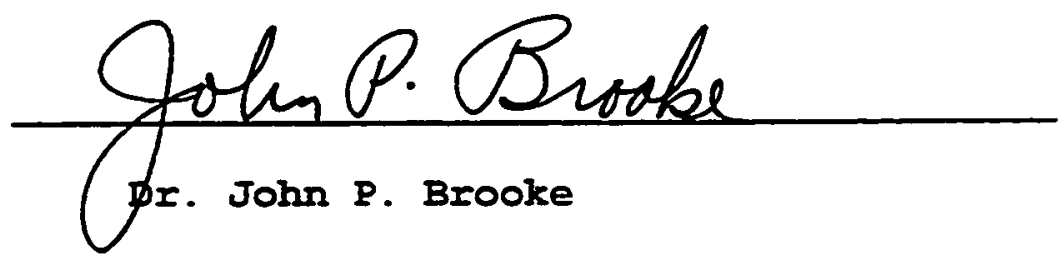

APPROVED FOR THE UNIVERSITY

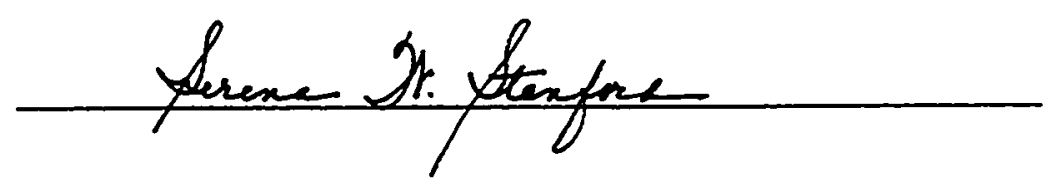




\begin{abstract}
THE RELATIVE IMPACT OF OFF-ROAD MOTORCYCLES

OF DIFFERING SIZES ON RATES OF MECHANICAL EROSION
\end{abstract}

By Joseph E. Mello, Jr.

The amount of detached soil produced by off-road motorcycles of four size classes was measured under controlled conditions on two hillslopes within the Hollister Hills State Vehicular Recreation Area, California. One of the hillslopes is underlain by rocks of sedimentary origin; the other is underlain by rocks of igneous origin.

Results of the study indicate that a mid-size off-road motorcycle with an engine displacement of 250 cubic centimeters ( 2 cycle) displaced the largest amount of soil. Conversely, the least amount of soil was displaced by the smallest class of motorcycles used for the study (engine displacement of less than 250 cubic centimeters). The largest class of motorcycles (engine displacement of more than 250 cubic centimeters) and the other mid-size class, an engine displacement of 250 cubic centimeters ( 4 cycle), displaced an intermediate amount of soil. 


\section{ACRMOKLEDEEMEHTS}

The author of this study would like to thank the volunteers from the Hollister Hills Off-Road Association and the personnel of the Hollister Hills State Vehicular Recreation Area who assisted with the tests. Without their assistance and cooperation, the performance of these tests would not have been possible. I would also like to thank the numerous students and employees of San Jose State University who assisted with the study. Without their help, the field work could not have been completed. I would like to thank my family, particularly my parents, for their constant support, and my wife, who at one time during one of the trials was "running" up and down the slopes with a belly full of babies (two, to be exact!). Iastly, but certainly not least, I would like to thank Dr. John williams for his assistance in designing this study and his general guidance in pulling this thesis together. 
TABLE OF CONTENTS

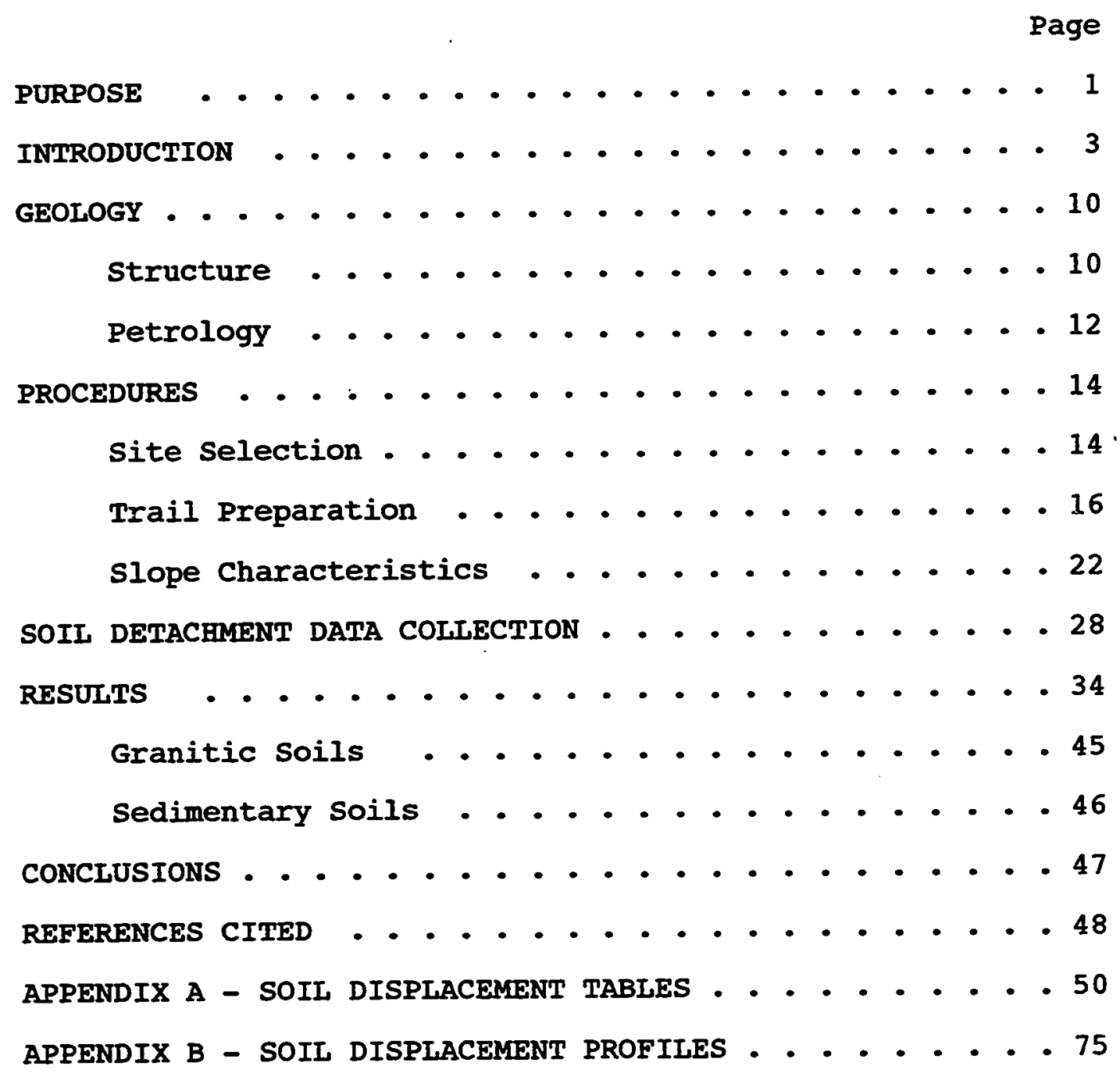




\section{IIST OF FIGURES}

Figure

Page

1. Study Area Location Map . . . . . . . - 4

2. Study Area Locations . . . . . . . . 6

3. Granitic Area Hillslope Profile . . . . . . 7

4. Sedimentary Area Hillslope Profile . . . . 8

5. Geologic Map . . . . . . . . . . . 12

6. Granitic Unit after Burning . . . . . . . 16

7. Sedimentary Unit prior to First Trial . . . 17

8. Soil Erosion Bridge . . . . . . . . . 19

9. Reference Stake in the Granitic Area . . . . 20

10. Measurements with a Copper Rod . . . . . . 21

11. Measurement from the Soil Bridge to the soil 22

12. Granitic Study Area with Fencing . . . . . 31

13. Motorcyclist during one of the Trials . . . 33

14. Soil Displacement in Sedimentary Area-Lane 1.36

15. Soil Displacement in Sedimentary Area-Lane 2 - 37

16. Soil Displacement in Sedimentary Area-Lane 3.38

17. Soil Displacement in Sedimentary Area-Lane 4 . 39

18. Soil Displacement in Granitic Area-Lane 1 . . 41

19. Soil Displacement in Granitic Area-Lane 2 . . 42

20. Soil Displacement in Granitic Area-Lane 3 . . 43

21. Soil Displacement in Granitic Area-Iane 4 . . 44 


\section{LIST OF TABLES}

Table $\quad$ Page

1. Motorcycle Use Survey . . . . . . . . . 2

2. Infiltration Rates . . . . . . . . . 24

3. Penetration Data ... . . . . . . . . 25

viii. 


\section{PURPOSE}

This study was conducted to determine the relative erosional impacts of different sizes of off-highway motorcycles on the trails within the Hollister Hills State Vehicular Recreation Area. Additional information was also desired on the impact of seasonal changes on the relative amounts of mechanical erosion induced by different sizes of motorcycles (i.e., what is the erosion rate difference for the different size motorcycles during the wet and dry seasons). At the present time, a variety of motorcycle sizes are being used by the recreational riders in the park. A survey conducted in February 1990 by park personnel at the Hollister Hills State Vehicular Recreation Area indicated that motorcycles used by various riders had engine displacements which ranged from less than 100 cubic centimeters (cc) to more than 500 cc (Table 1). 


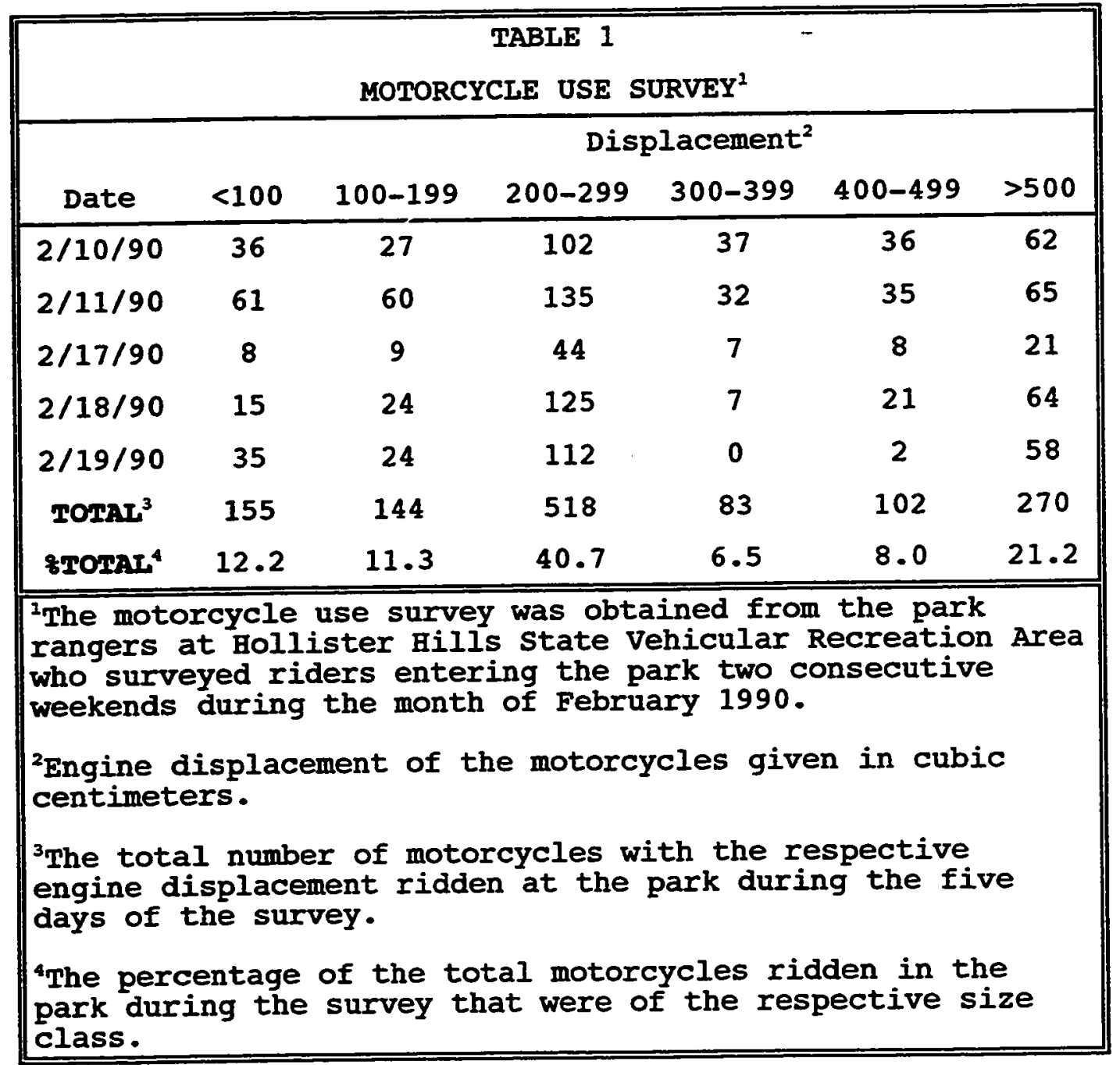


IXIRODUCTION

Motorcycle and other off-road vehicle use is widespread on publicly owned lands in the state of California (Sheridan, 1980). In California, as of April 1994, there were over 100,000 miles of vehicle-access-roads and trails at more than 200 sites owned and/or operated by county, state, or federal entities (California Department of Parks and Recreation, 1994) - Seven off-road vehicle parks occupying a total of 71,650 acres of land are managed by the California Department of Parks and Recreation, Off-Highway Motor Vehicle Recreation Division (California Department of Parks and Recreation, 1994). To measure the amount of mechanical erosion produced by motorcycles of varying engine displacements, this study was conducted at the Hollister Hills State Vehicular Recreation Area (Figure 1), the third largest and fourth most utilized of the state-operated offroad vehicle parks (California off-Highway Motor Vehicle Recreation Commission, 1992).

One of the most important and long-lasting effects of off-road vehicle use is the compaction of soil caused by the force of rolling wheels (Webb, Ragland, Godwin, and Jenkins, 1978). Soil compaction is known to be a contributing factor to accelerated soil erosion (Snyder, Frickel, Hadley, and 


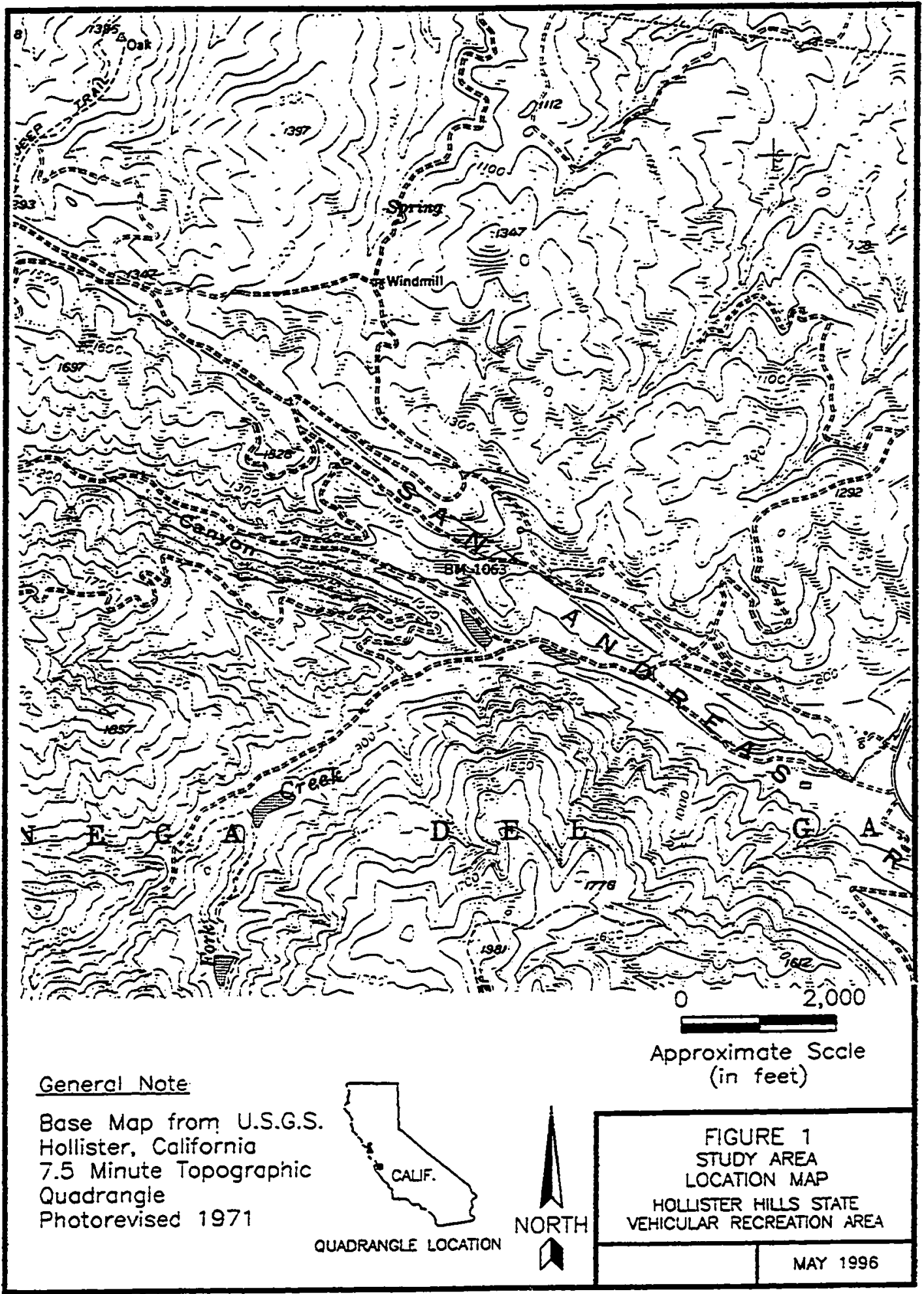


Miller, 1976). Additionally, wheels with excess spin, particularly during an uphill climb, tend to accelerate the detachment (and subsequent erosion) and mixing of the soil. Mixing of soil, resulting in the loss of the layered structure or profile, decreases the ability of the soil to support plants and increases the potential for erosion (Bennett, 1973). At the Hollister Hills State Vehicular Recreation Area, sediment yields of various areas within the park ranged from 0 to 6574 tons per square mile during the period July 1989 through June 1990 (Harden, 1991).

Mechanical erosion produced by four sizes of motorcycles (<250 cubic centimeters (cc) of engine displacement, $250 \mathrm{cc}$ of engine displacement ( 2 cycle), 250 cc of engine displacement ( 4 cycle), and $>250 \mathrm{cc}$ of engine displacement) was measured in two geographically separate areas (Figure 2) of soil derived from 1) sedimentary and 2) igneous rock units. Tests were conducted in May, August, November 1990, and March 1991 in the Hollister Hills State Vehicular Recreation Area within the central coast ranges of California, approximately 80 miles southeast of San Francisco (Figure 1). Tests were initiated on undisturbed ground with trails developing normal to the hillslope contours (Figures 3 and 4 ). Multiple motorcycles were ridden over each trail by individuals with varying 


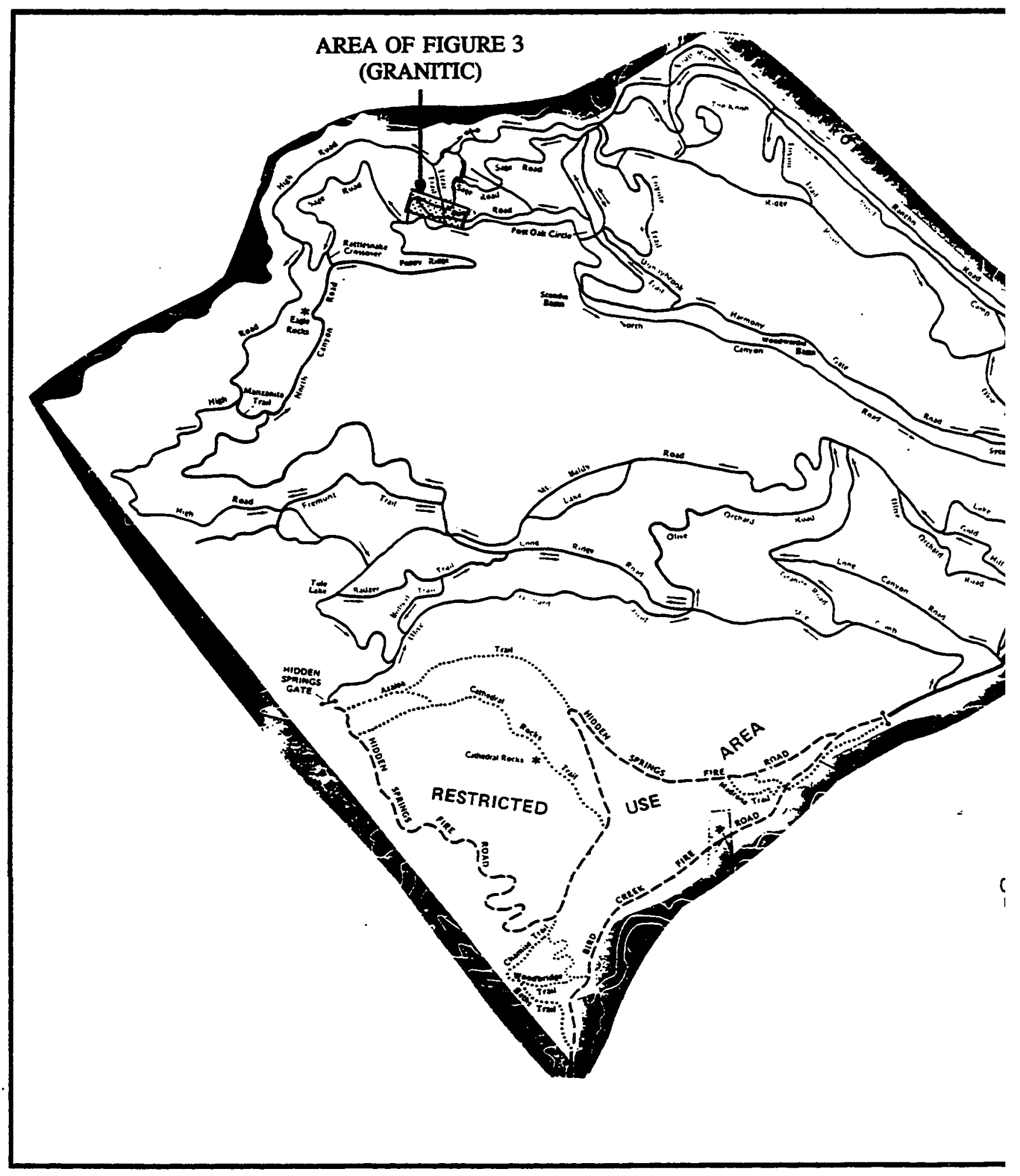





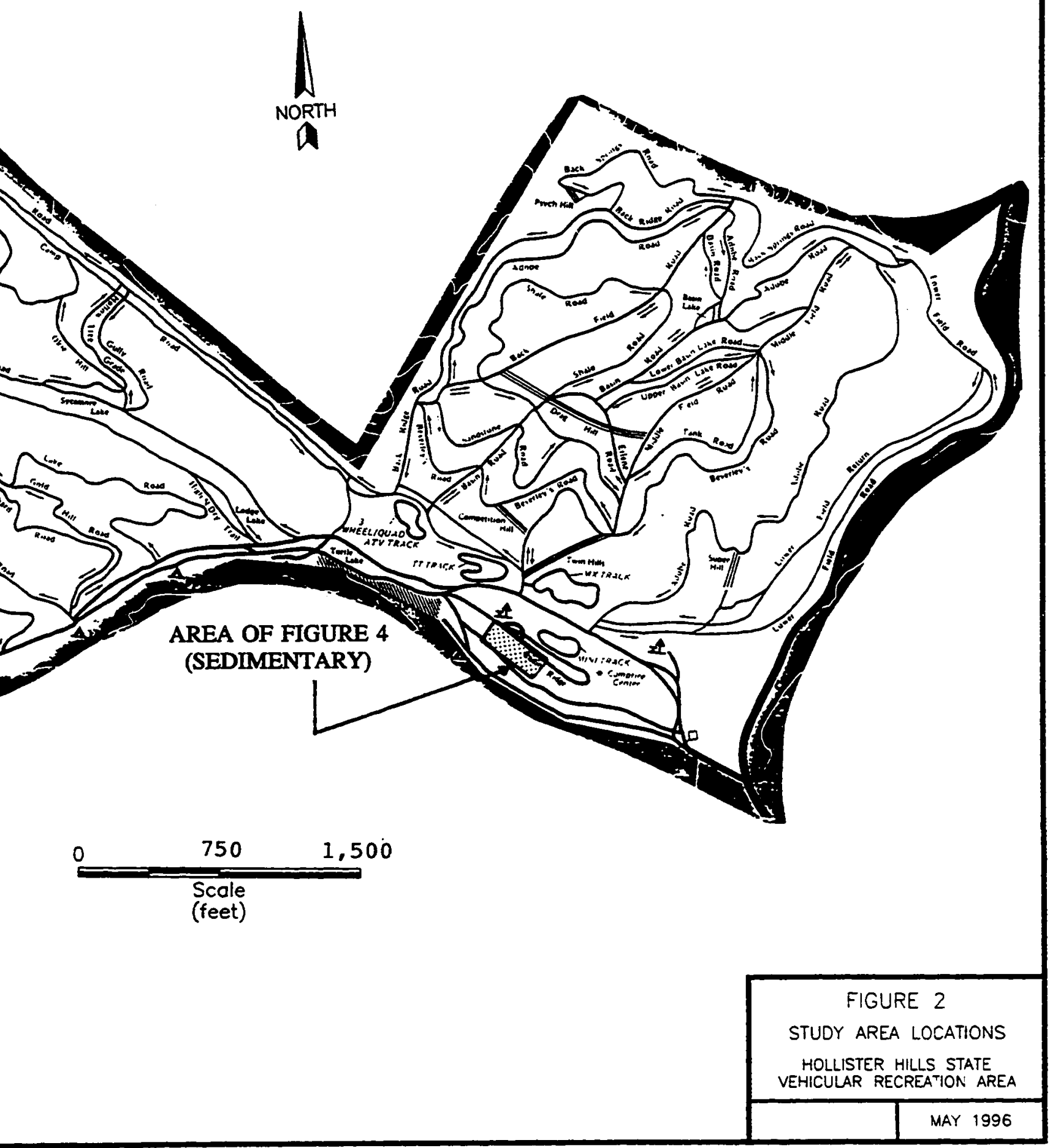





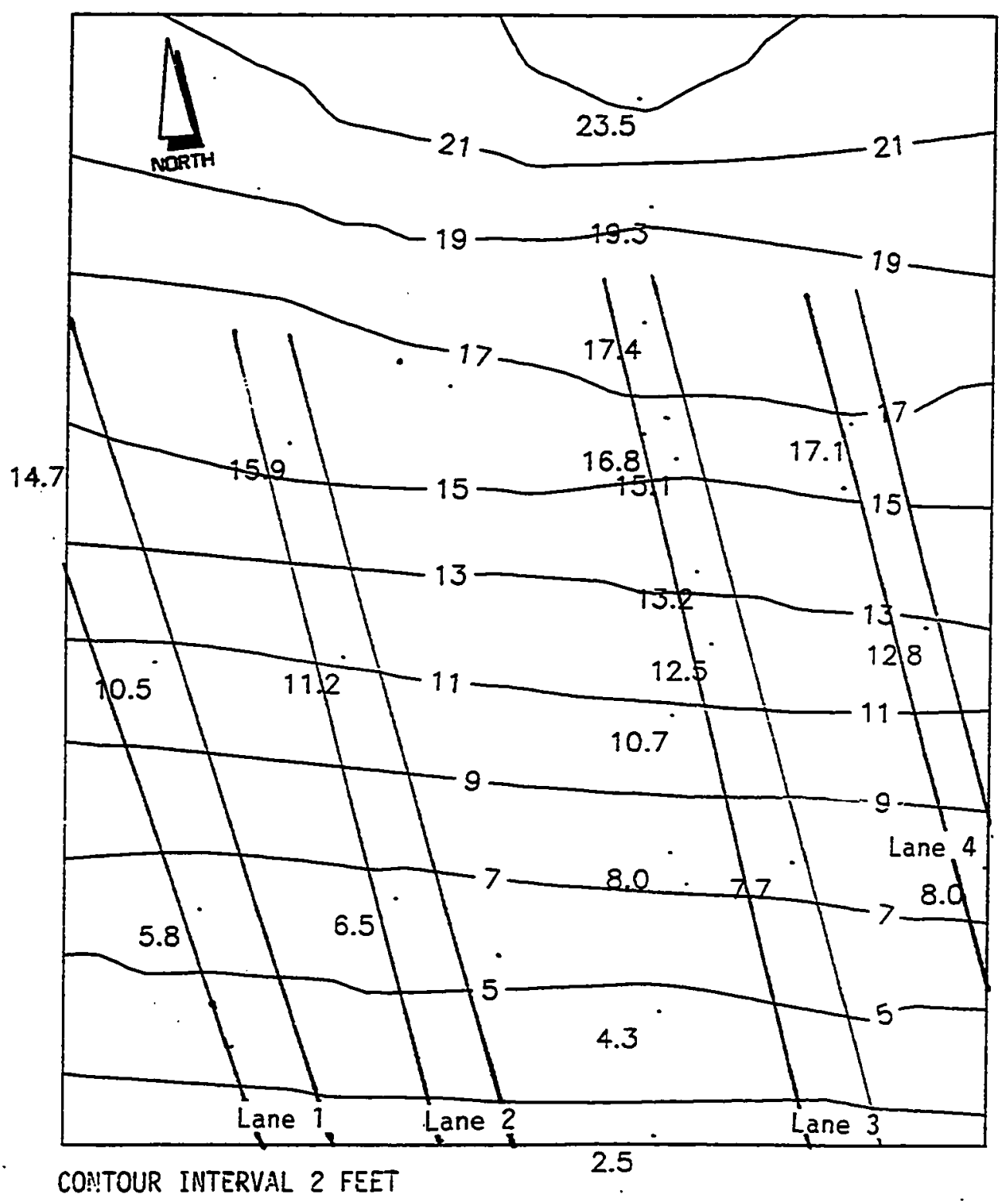

SCALE 1 inch $=7$ FEET

FIGURE 3

GRANITIC AREA

HILLSLOPE PROFILE

HOULISTER HILLS STATE

VEHICULAR RECREATION AREA 


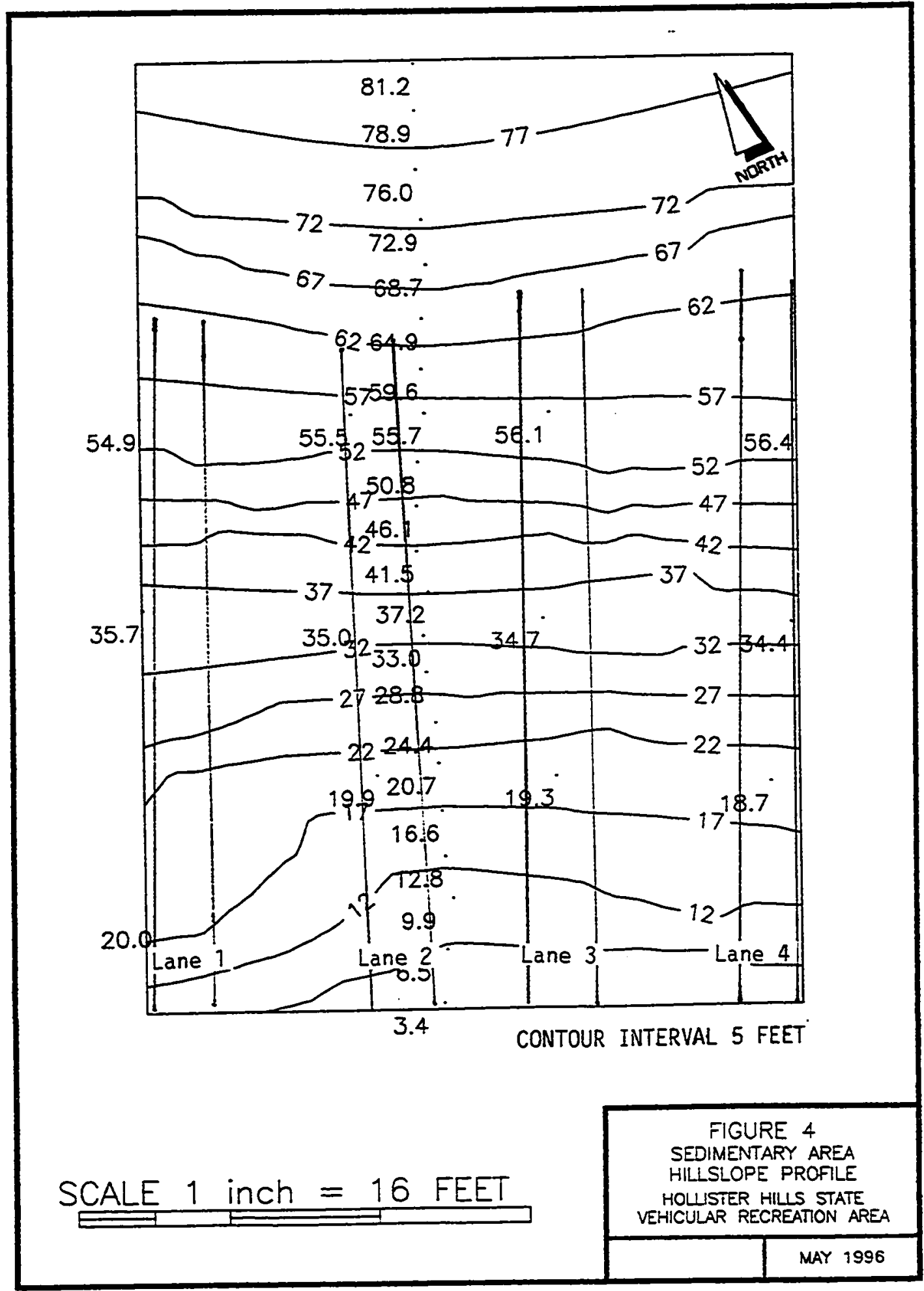


experience. Separate but equivalent trails .were established within each soil area for each motorcycle size. Comparison of microprofiles taken across the trails before the initial tests and after each trial permitted the determination of the amount of material detached (thus defined as eroded) from the slope by the motorcycles during a designated number of runs. Baseline properties of the slopes (dimensions, profiles, aspect, vegetative cover) and the respective soils (density, unit weight, penetration resistance, infiltration rates) were established before the tests. 
GEOLOGY

Information about the relative impact of differentsized motorcycles on the rates of mechanical erosion on offhighway trails is limited. In the Hollister Hills area, this question is complicated by the fact that the recreational area and its assorted trails are underlain by two different rock types and thus, by soils with very different mechanical properties. These rock types are: 1) a sedimentary sequence, primarily sandstone and shale; and 2) igneous rocks, primarily of granitic origin.

\section{Structure}

Hollister Hills State Vehicular Recreation Area is located within the Gabilan Range of the Coast Ranges in central California approximately 2.7 miles south-southwest of the Hollister Valley (Figure 1). Extensive folding and faulting of the province has created the northwest-trending ranges. In general, the coast Ranges in central California contain sedimentary deposits of both marine (Coast Range ophiolite) and terrestrial (Great valley sequence) origin underlain by either the Franciscan complex on the east side of the San Andreas fault or granitic rocks of the Salinian Block on the west side of the fault (Wallace, 1990). 
Several strands of the San Andreas fault system bisect the study area, including the primary trace of the San Andreas fault (Rogers, 1993) (Figure 5). Other faults parallel to the San Andreas Rift zone are located within or near the Hollister Hills State Vehicular Recreation Area property boundaries, including the Harris Ranch fault and the Bird Creek fault (Figure 5).

Steinbrugge and zacher (1960) first recognized that aseismic slip or "creep" occurred along the San Andreas fault at the Almaden Cienega Winery, which is located approximately 2 miles southeast of the entrance to the study area. According to Schulz, Mavko, Burford, and stuart (1982), the San Andreas fault creep has been measured at a rate of 1.3 centimeters per year $(\mathrm{cm} / \mathrm{yr})$ in the vicinity of the site (at the Almaden Cienega winery), while the present overall rate of relative movement between the Pacific (west of the fault) and North American (east of the fault) plates is thought to be approximately $4.8 \mathrm{~cm} / \mathrm{yr}$ (DeMets, Gordon, Stein, and Argus, 1987). Aseismic slip on the Calaveras fault approximately 3 miles east of the study area has also been measured at $1.3 \mathrm{~cm} / \mathrm{yr}$ (Lisowski and Prescott, 1981). 


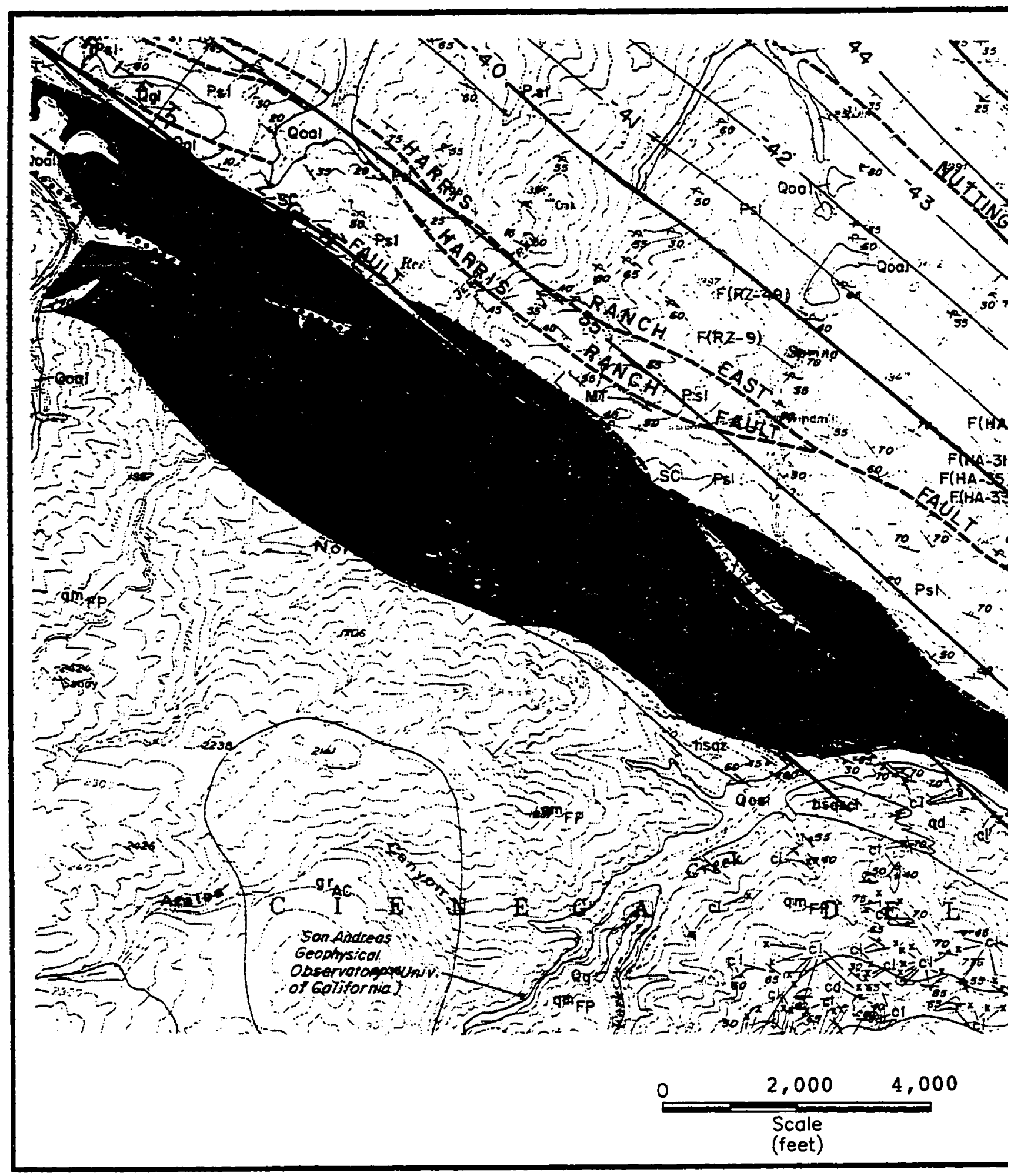





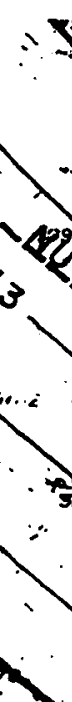
o

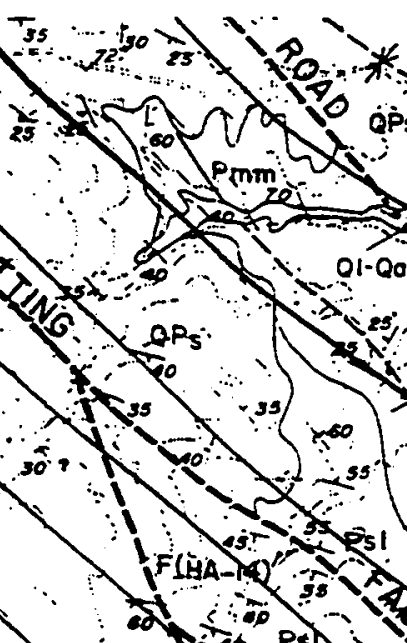

$F(H)-13 k$

$F(n-3) \Rightarrow 2 n+50$ F(HA-S5) E. EAHA-3ज : (a)

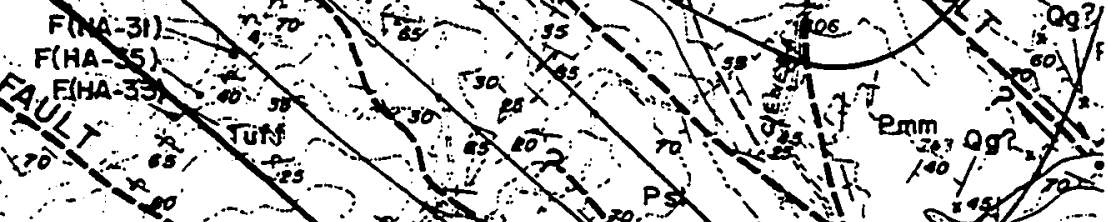
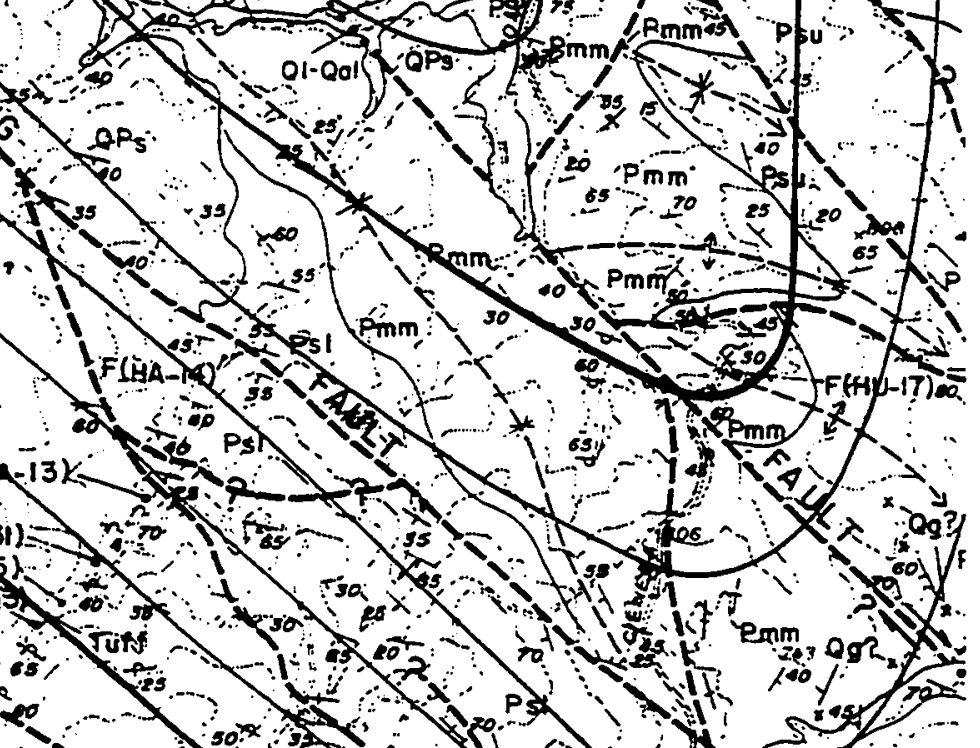

$\therefore / 400$. Psu

(5) sox is
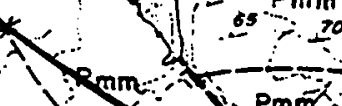

imm $\operatorname{man}$ 10 $=-1 y^{25}$ $20 \log ^{20}$ so5 o. $1 \times x_{\mathrm{mm}}$ 14 $\therefore:$

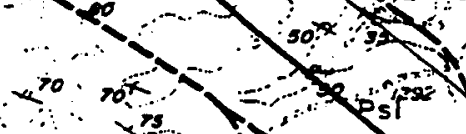

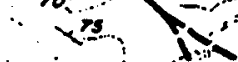

ins
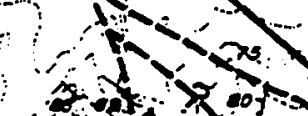

of psyot

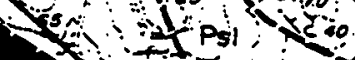

(
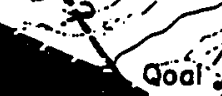

cool
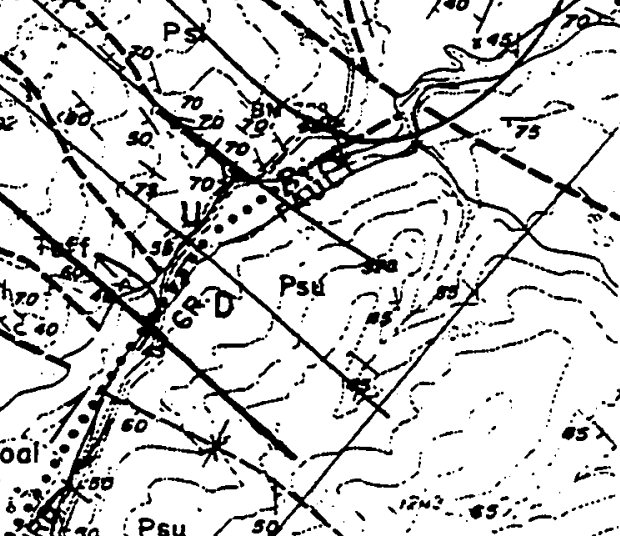
ags/ln
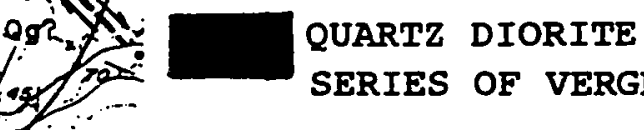
SERIES OF VERGELES

PURISIMA FORMATION

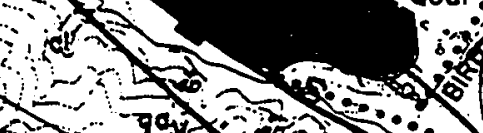

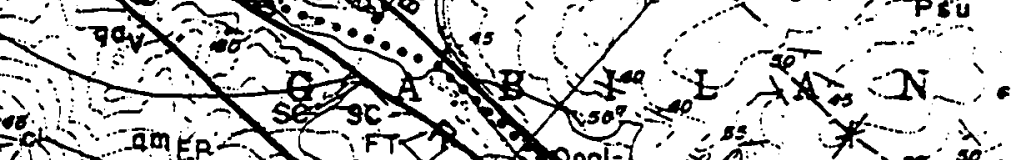

FIGURE 5

GEOLOGIC MAP

HOLLISTER HILLS STATE VEHICULAR RECREATION AREA

NOTE: GEOLOGIC MAP OBTAINED FROM ROSS (1993) 



\section{Petrology}

Rocks southwest of the San Andreas fault in the study area belong to the quartz diorite series of Vergeles (Ross, 1972)(Figure 5). Vergeles is a fault located northwest of the study area. The quartz diorite is described by Rogers (1993) as a commonly-foliated medium-grained hornblende quartz diorite. Soils on this unit are referred to as derived from the "granitic" area in this text.

Rocks northeast of the san Andreas fault in the study area belong to the marine sandstone member of the Purisima Formation (Figure 5). In the vicinity of the study area, the Purisima Formation is a brown and gray, medium-grained, well-sorted sandstone with gray shale and mudstone (Rogers, 1993). Soils on this unit are referred to as derived from the "sedimentary" area in this text. 


\section{PROCEDURES}

This study was designed and conducted during the period 1 February 1990 to 30 June 1991. In cooperation with park personnel, two test areas were selected within the recreation area (see Figure 2 on page 4 ). One area is underlain by sedimentary rocks. This area is commonly referred to as the "adobe area" by park personnel because of the presence of the clay-rich soils which develop on the sedimentary rocks. The second area is underlain by granitic rocks. Each of the areas was believed to be pristine, in that no trail development had occurred on either site. It was the expectation that the slopes in these areas could be utilized by the majority of riders and would provide representative data for many of the typical slopes within the recreation area.

\section{Site Selection}

Prior to selecting the study locations, Dr. John Williams and I were escorted by park personnel to several potential study areas in each of the different geologic regimes. Areas were inspected for physical attributes including the following: slope (minor incline), soil type, vegetative cover, lack of vehicle use, and rideability. Within the granitic area, there are few motorcycle trails; 
the majority of the ground surface is covered with brushy vegetation and trees. Most of the area underlain by sedimentary rocks is covered with various grasses; the majority of the sedimentary area has been used by off-road vehicles. Based on the results of the visual survey and discussions with park personnel, the two areas shown on Figure 2 on page 4 were selected to conduct the tests.

Soil in the granitic area is covered with oak-chaparral vegetation, which generally inhibits off-road vehicle use. The study area selected within the granitic area was covered with chaparral prior to trail preparation (Figure 6). Based on the type of vegetation covering the granitic study area and discussions with park personnel, it is highly unlikely that this study site was ever utilized by off-road vehicles prior to the conduct of this study.

Because the majority of the area underlain by sedimentary rocks is covered with grasses (which do not inhibit off-road vehicle traffic), most areas within the sedimentary unit have been used by off-road vehicles. While park personnel suggested that most areas underlain by sedimentary rocks have been used by off-road vehicles, they could not recall whether the selected area within the sedimentary unit (Figure 7) had ever been utilized by off- 
road vehicles. Other areas within the sedimentary area checked during the site inspection had been utilized by offroad vehicles.

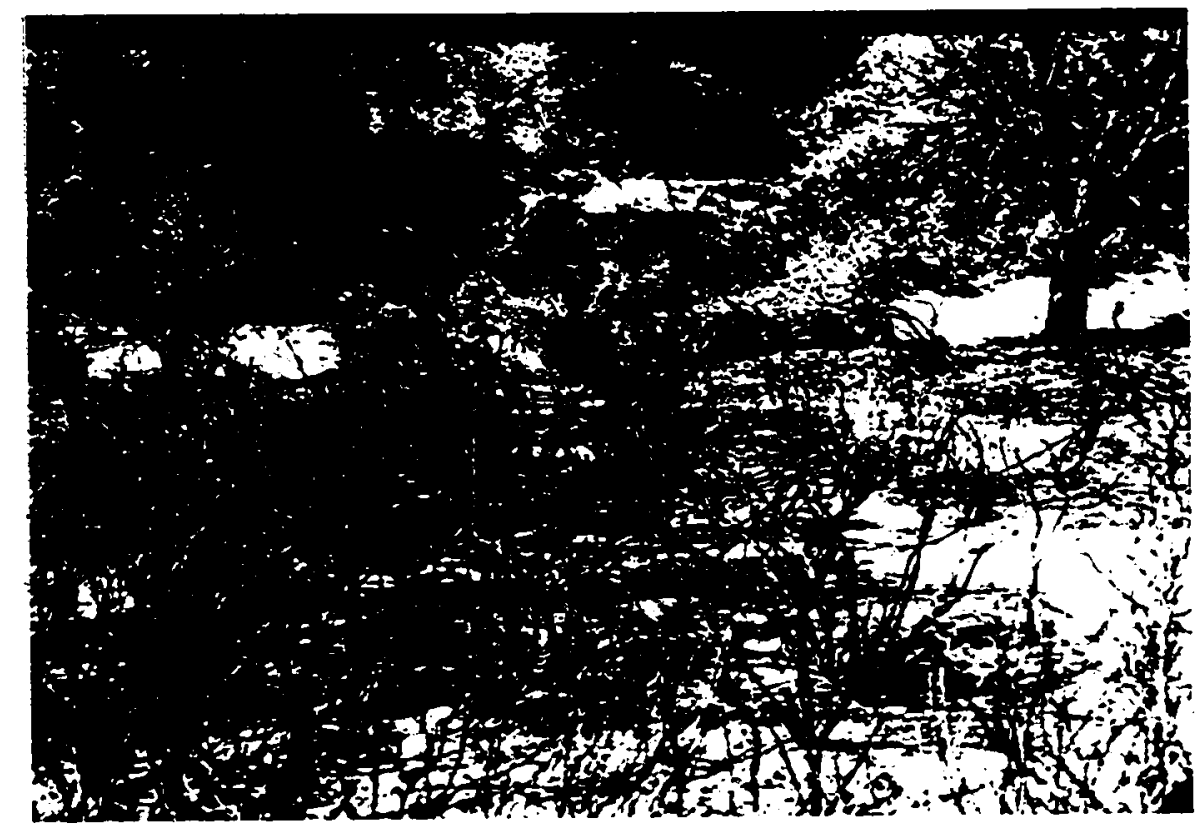

Figure 6. Photograph showing the study area underlain by the granitic unit after burning of the chaparral but prior to clearing of the cinder and trail preparation.

\section{Trail Preparation}

After the two study areas had been selected, personnel of the park and San Jose State University prepared the areas for motorcycle use. In the granitic area, brush was burned and then removed by hand. After removal of the burned vegetation, soil was exposed without cover. Care was 
exercised to limit the disturbance of topsoil prior to the first test. In the sedimentary area, the grasses do not inhibit off-road vehicle usage. Vegetation was, therefore, left intact until the first test.

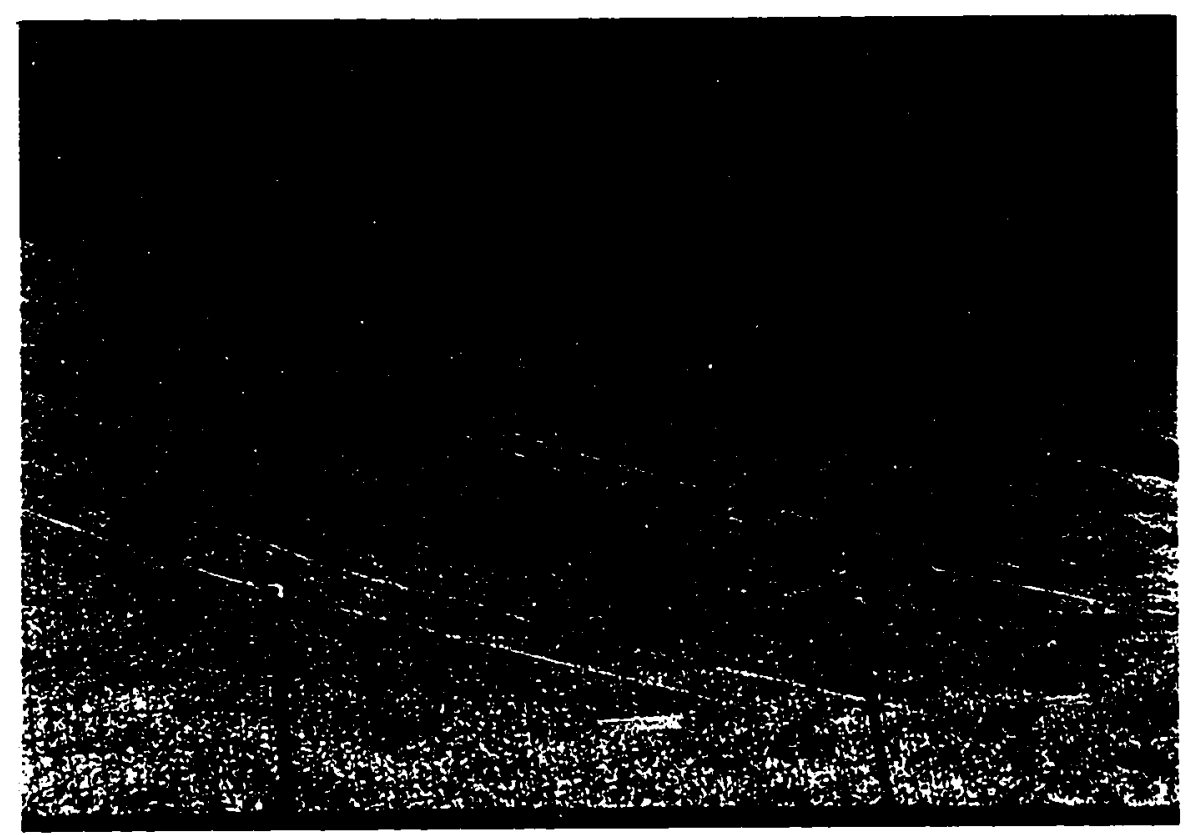

Figure 7. Photograph showing the study area underlain by the sedimentary unit prior to the first trial.

On each of the slopes four parallel trails, each approximately 6 feet wide and perpendicular to the hillslope contours, were delineated with colored tape to provide restricted pathways for the motorcycles. Variability of the trail sites in initial vegetative cover, inclination, and underlying materials was minimized. Each trail was 
designated for a particular motorcycle size, specifically: less than $250 \mathrm{cc} ; 250 \mathrm{cc}$ with a 4-stroke engine; $250 \mathrm{cc}$ with a 2-stoke engine; and greater than $250 \mathrm{cc}$. These four groups of motorcycle sizes are representative of the sizes currently being used within the recreational area and those which will be used in the foreseeable future (Table 1).

Microprofiles across the trails parallel to topographic contours were established near the base of the slope, at mid-slope, and near the crest of the slope. These microprofiles were measured using a soil erosion bridge (Figure 8). This is an accepted method by which detailed profiles can be established and subsequent changes detected (Anders and Leatherman, 1987).

Specific procedures utilized to implement the soil erosion bridge were modified from the procedures outlined in two United States Department of Agriculture, Forest Service (USFS) internal memoranda (USFS, 1988; 1989). These procedures included:

- Emplacing three equaliy spaced reference stakes (Figure 9) per trail on each side of the trail. The same reference stakes were used throughout the study. Where adjacent trails in the granitic area 
were close, a single reference stake was used for both trails.

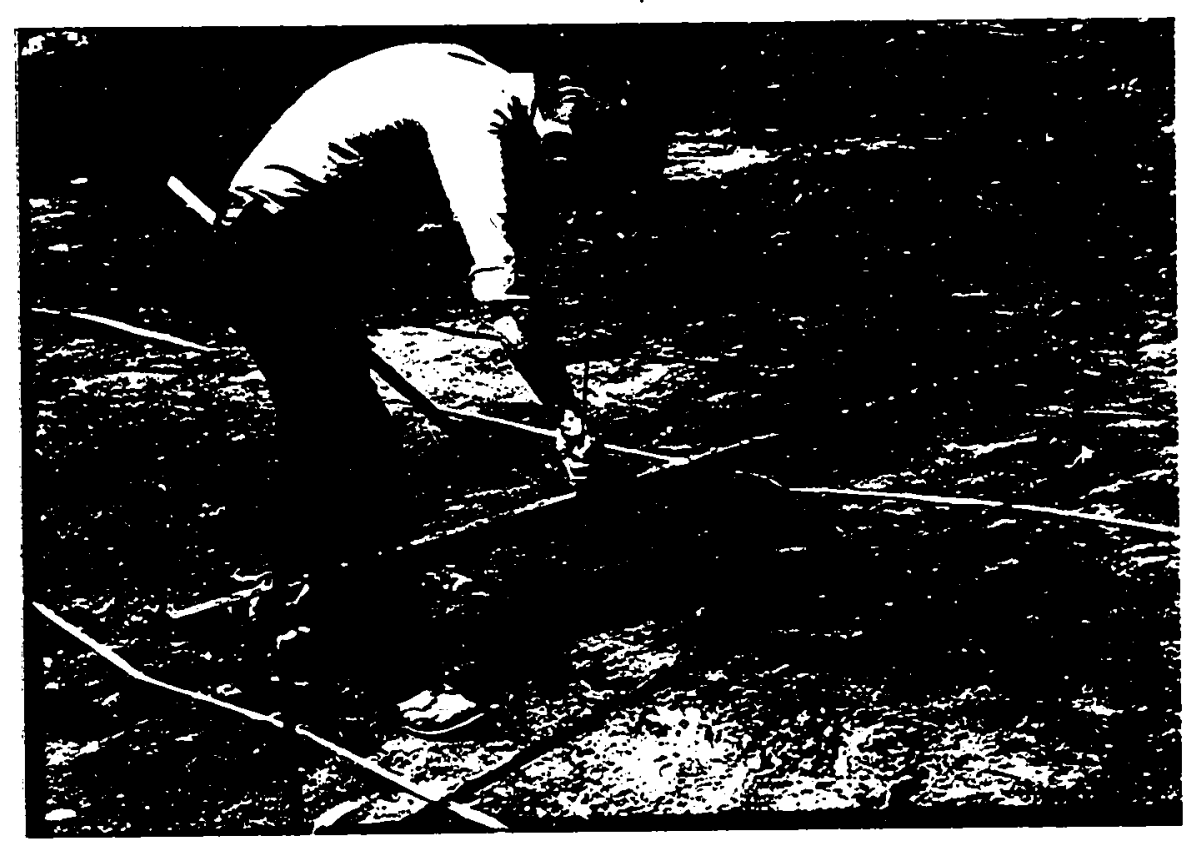

Figure 8. Photograph showing the soil erosion bridge utilized to measure the amount of detached soil within the trails.

- After emplacement of the reference stakes, a metal rod with an attachment sleeve was inserted on top of the reference stakes on either side of the trail (Figure 10). 


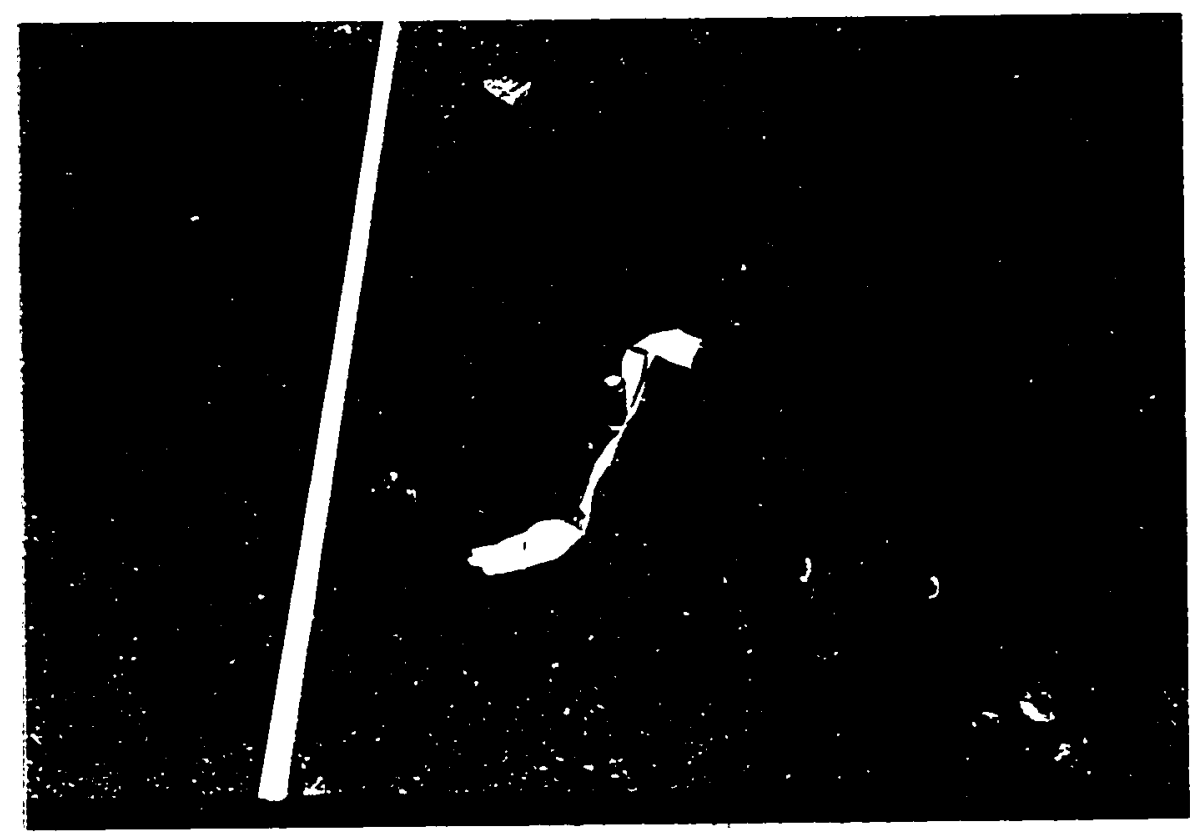

Figure 9. Photograph showing the reference stake used for Profile 2 of Lanes 3 and 4 within the granitic study area.

- An aluminum "bridge" with holes drilled every three inches was then attached to the metal rods with clamps (Figures 10 and 11). The bridge was checked for evenness with a carpenter's level each time it was attached to the metal rods. 


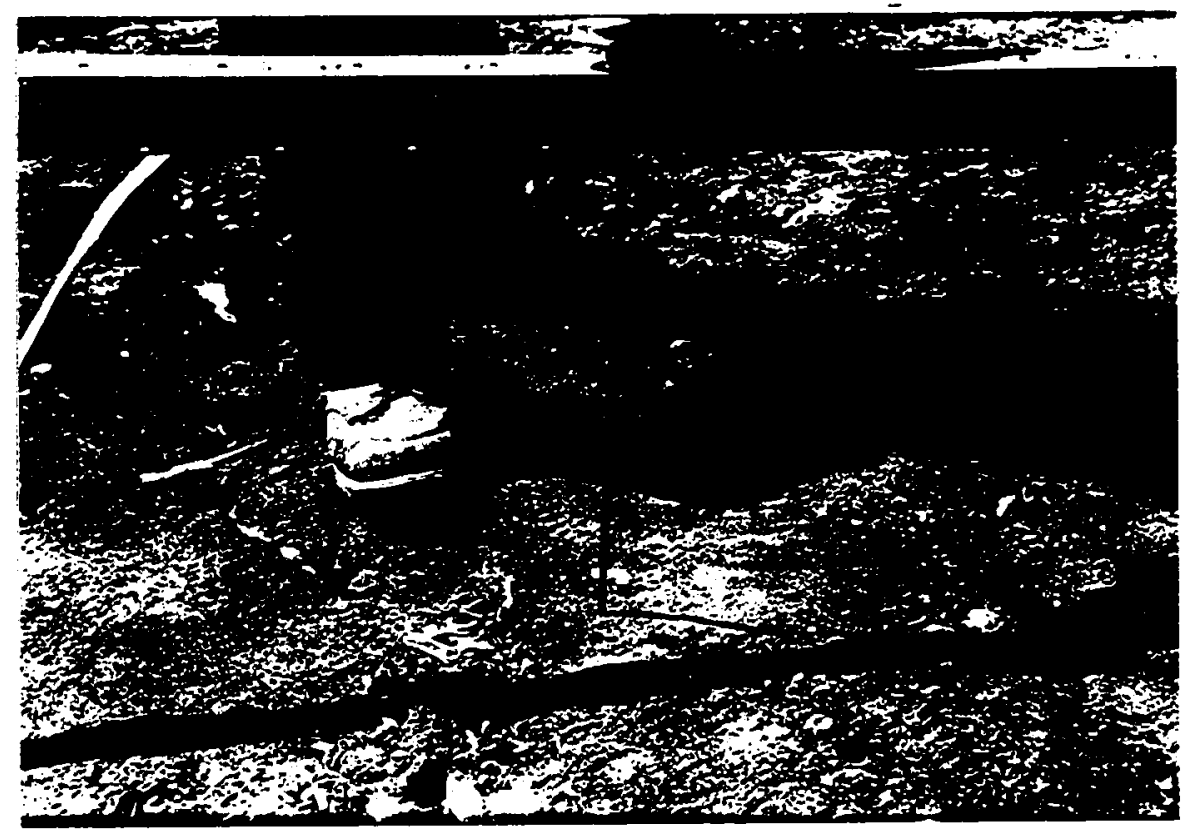

Figure 10. Photograph showing the procedure used for obtaining measurements of the trail with a copper rod.

- Measurements were obtained by inserting a copper rod into the drill holes along the soil bridge (Figure 10). The copper rod was allowed to just touch the ground surface so that detached soil would not be excluded from the measurement. The distance from the top of the soil bridge to the top of soil was then measured (Figure 11). 


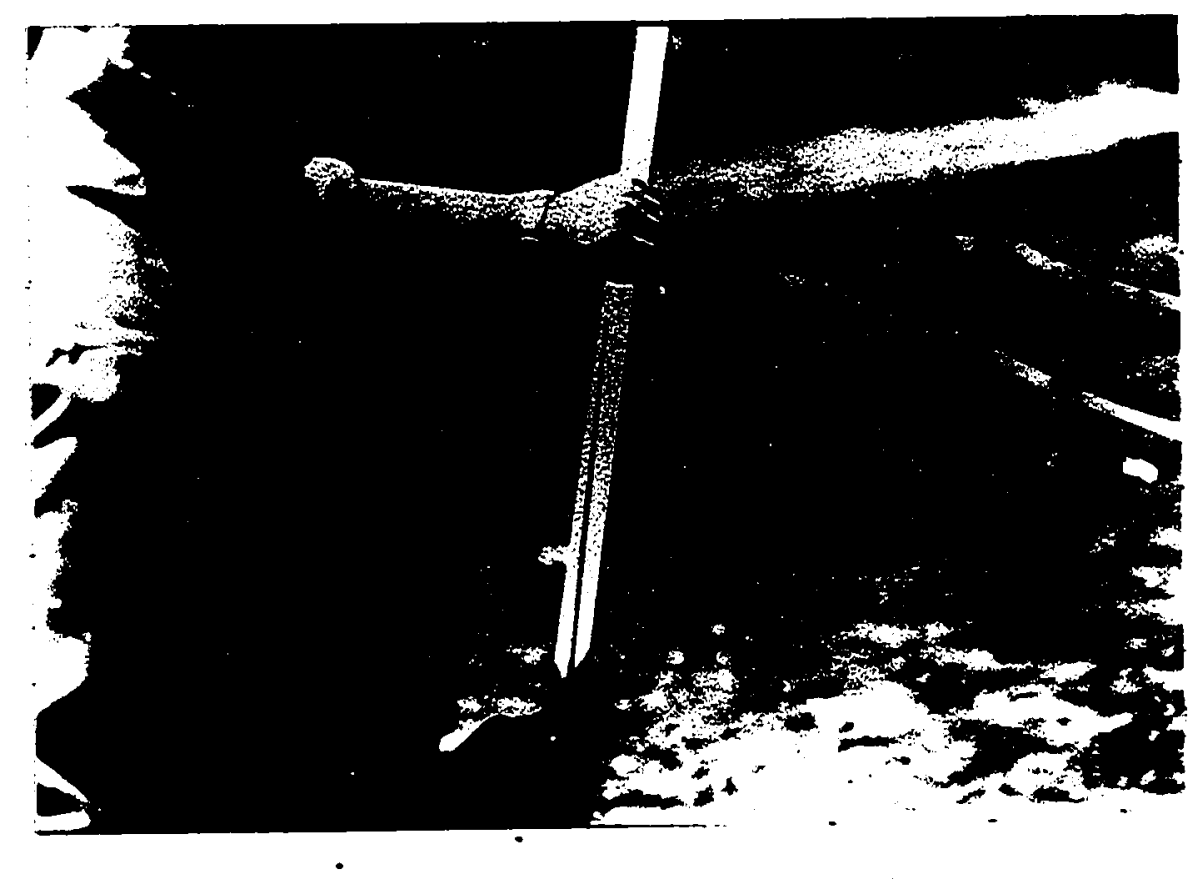

Figure 11. Photograph showing the procedure for the measurement of distance from the top of the soil bridge to the soil.

- A point outside the trail area adjacent to each respective reference stake was established as a reference point for elevation. It was assumed that the reference point elevation would not vary significantly during the test period.

\section{Slope Characteristics}

Characteristics of each slope were measured, including their profiles (Figures 3 and 4) geologic composition (granitic or sedimentary), infiltration rates (Table 2), and 
surface resistance to penetration (Table 3), prior to beginning the tests. Infiltration rates and resistance to penetration were measured prior to the onset of testing and after the first trial (175 passes) on each hillslope. The infiltration rates were measured four days prior to the first test (Pre-test) and nine days after the first test (Post-test).

After the trails were prepared and the baseline stakes were set, the slopes were surveyed with an electronic distance meter. Selected locations along the trails were measured for distance and elevation relative to the respective base of the hillslope. Profiles (contour maps) of the hillslopes were prepared based on the data obtained during the survey (Figures 3 and 4 ).

To measure the impact of motorcycles on the infiltration rate and capacity of the soil, an infiltration test was conducted prior to the study. Infiltration is defined as the flow of water downward from the land surface into and through the upper layers of the soil (Fetter, 1980). Infiltration capacity is defined as the maximum rate at which infiltration can occur under specific conditions of soil moisture (Fetter, 1980). For a given soil, the infiltration capacity is a function of the water content. 


\begin{tabular}{|c|c|c|c|c|}
\hline \multicolumn{5}{|c|}{$\begin{array}{c}\text { TABLE } 2 \\
\text { INFILTRATION RATES }{ }^{1}\end{array}$} \\
\hline TIME $^{2}$ & $\begin{array}{l}\text { SEDIMENTARY } \\
\text { (PRE-TEST) }\end{array}$ & $\begin{array}{l}\text { SEDIMENTARY } \\
\text { (POST-TEST) }\end{array}$ & $\begin{array}{l}\text { GRANITIC } \\
\text { (PRE-TEST) }\end{array}$ & $\begin{array}{c}\text { GRANITIC } \\
\text { (POST-TEST) }\end{array}$ \\
\hline 10 & $16 \cdot 4^{3}$ & 10.0 & 98.1 & 23.9 \\
\hline 20 & 7.85 & 3.79 & 78.5 & 11.0 \\
\hline 30 & 7.19 & 2.09 & 70.6 & 9.03 \\
\hline 40 & 5.23 & 1.64 & 63.4 & 8.63 \\
\hline 50 & 3.92 & 1.57 & 58.2 & 8.37 \\
\hline 60 & 3.27 & & 55.6 & \\
\hline 70 & & & 54.9 & \\
\hline 80 & & & 54.9 & \\
\hline 90 & & & 54.6 & \\
\hline 100 & & & 53.0 & \\
\hline $\begin{array}{l}{ }^{1} \text { Infilt } \\
\text { hillsl } \\
{ }^{2} \text { Time i } \\
\text { infilt } \\
{ }^{3} \text { Infilt } \\
\text { infilt }\end{array}$ & $\begin{array}{l}\text { ation rates } \\
\text { pe between Pr } \\
\text { measured in } \\
\text { tion test. } \\
\text { ation rates } \\
\text { tion per hou }\end{array}$ & $\begin{array}{l}\text { ere obtained } \\
\text { files } 1 \text { (top } \\
\text { minutes afte } \\
\text { re presented } \\
\text {. }\end{array}$ & $\begin{array}{l}\text { rom Lane } 2 \\
\text { and } 2 \text { (mid } \\
\text { the beginn } \\
\text { is centimet }\end{array}$ & $\begin{array}{l}\text { le) } \\
\text { le of the } \\
\text { s of }\end{array}$ \\
\hline
\end{tabular}




\begin{tabular}{|c|c|c|c|c|}
\hline \multicolumn{5}{|c|}{$\begin{array}{c}\text { TABLE } 3 \\
\text { PENETRATION DATA }\end{array}$} \\
\hline \multirow{2}{*}{$\begin{array}{c}\text { DATA } \\
\text { POINTS }\end{array}$} & \multicolumn{2}{|c|}{ SEDIMENTARY UNIT } & \multicolumn{2}{|c|}{ GRANITIC UNIT } \\
\hline & (PRE-TEST) & (POST-TEST) & (PRE-TEST) & (POST-TEST) \\
\hline 1 & $514^{2}$ & 735 & $68 / 437 / 451^{3}$ & $547 / 430$ \\
\hline 2 & 620 & 710 & $52 / 313 / 324$ & $479 / 307$ \\
\hline 3 & $370 / 579$ & 547 & $104 / 333 / 341$ & $677 / 521$ \\
\hline 4 & 340 & 496 & $93 / 373 / 377$ & $602 / 546$ \\
\hline 5 & 464 & 740 & $108 / 220 / 235$ & $503 / 347$ \\
\hline 6 & 478 & 723 & $112 / 240 / 271$ & $720 / 409$ \\
\hline 7 & 430 & 577 & $165 / 369 / 369$ & $459 / 332$ \\
\hline 8 & 482 & 603 & $41 / 217 / 295$ & $549 / 409$ \\
\hline 9 & 591 & 765 & $23 / 227 / 571$ & $484 / 447$ \\
\hline 10 & $301 / 459$ & 692 & & $495 / 724$ \\
\hline 11 & 260 & 752 & & $616 / 517$ \\
\hline 12 & 378 & 607 & & $641 / 498$ \\
\hline 13 & 401 & 804 & & $493 / 447$ \\
\hline 14 & 397 & 876 & & $561 / 515$ \\
\hline 15 & 389 & 716 & & $543 / 364$ \\
\hline 16 & $284 / 456$ & 651 & & $696 / 540$ \\
\hline 17 & 334 & 641 & & \\
\hline \multicolumn{5}{|c|}{$\begin{array}{l}{ }^{1} \text { Data points were located at various places on pristine } \\
\text { hillslopes and on the trails after the first test. } \\
{ }^{2} \text { Penetration is presented in pounds per square inch. } \\
\text { 3Penetration data were obtained at the ground surface, } 6 \\
\text { irches below the ground surface, and } 12 \text { inches below the } \\
\text { ground surface. When only one number is given, } \\
\text { penetration at } 6 \text { inches was refusal. when two numbers } \\
\text { are given, penetration at } 12 \text { inches was refusal. }\end{array}$} \\
\hline
\end{tabular}


A double ring infiltrometer test designed in general accordance with the American Society for Testing and Materials (ASTM) standard Test Method for Infiltration Rate of Soils in Field Using Double-Ring Infiltrometers (serial designation $\mathrm{D}$ 3385-75) was used to conduct the infiltration test. The double ring infiltrometer is used to prevent divergent flow in layered soils by providing an outer water barrier to encourage only vertical flow in the inner ring (ASTM, 1990). The following procedures were utilized during the infiltration test in general accordance with the ASTM standard (1990):

- Two open cylinders, one inside the other, were driven into the soil.

- The annulus between the two cylinders was partially filled and maintained at a constant level throughout the test.

- The inner cylinder was then filled with water to a certain level; water was measured and added to the inner cylinder intermittently during the test.

- At the end of 10 minutes, and each successive 10 minute interval thereafter, the inner ring was 
filled to the original level. The amount of water utilized over the respective 10 minute period was recorded and tabulated.

- The test was terminated when the infiltration rate began to stabilize.

- After the impact of motorcycles, the infiltration rate decreased over 50 percent in the sedimentary area and over 80 percent in the granitic area (Table 2).

Penetration tests were also conducted with a penetrometer prior to and after the initial trial in each area to measure the impact of motorcycle usage on the resistance to penetration of the soil. The penetration tests were conducted at selected locations on the slopes within the two study areas. The penetrometer was pushed into the ground and measurements of the amount of force applied to the penetrometer (in pounds per square inch) were obtained at the surface, at 0.5 foot below the ground surface, and at 1.0 foot below the ground surface. Resistance to penetration, particularly after the first trial, prohibited obtaining measurements at the 0.5 and 1.0 foot intervals at some locations. After the first trial, 
the resistance to penetration increased by approximately 65 percent at the ground surface in the sedimentary area and by approximately 565 percent at the ground surface and 50 percent at 0.5 foot below grade in the granitic area (Table 3). 


\section{SOIL DEIACEMIRT DATA COLLECTION}

Prior to the onset of the test, four data collection dates were scheduled during the period 1 February 1990 through 30 June 1991. The dates 5 May, 18 August, 3 November 1990, and 2 February 1991 were chosen because they would typically occur during different weather periods affecting the recreation area. These different dates traditionally would have provided an opportunity to analyze the influence of the soil moisture content on the relative amounts of mechanical erosion (tire generated) by different sized motorcycles on the trails. Because of the continuing drought that central California had been experiencing during the test period, however, the variation in soil moisture content on the dates was not significant. In an attempt to provide more variability in soil moisture, the trial date initially set for 2 February 1991 was postponed until March 1991 in anticipation of storms forecasted for later during the month of February. Unusually heavy rains preceding the trial in March 1991 were too late to be helpful in terms of providing the desired soil moisture variability during these tests and made the trails impassable. The study was discontinued after the failed March 1991 attempt. 
Each of the tests was conducted in the following

manner:

- Riders participating in the tests belonged to the Hollister Hills Off-Road Association, an organized group of riders who work with the park personnel for the improvement of the sport and the facilities at the park. The membership of the Association is variable in terms of age, riding experience, sex, weight, brand of motorcycle, type of motorcycle tire, etc. For the purpose of these tests, it is believed that this variation of factors among these riders simulates the variability present in the collective general ridership within the recreational area. Thus, the impact on trail development by these riders forecasts the impact of the recreational area's general ridership.

- Prior to any riding on the trails on a trial day, and prior to the onset of the study, baseline profiles for each of the trails were measured using the soil bridge at the base, mid-slope, and crest of the trail, using reference metal stakes 
which remained in the hillslope for the duration of the study.

- The trial areas were marked and secured by fencing and flagging to prevent unauthorized riding on the test surfaces (Figure 12).

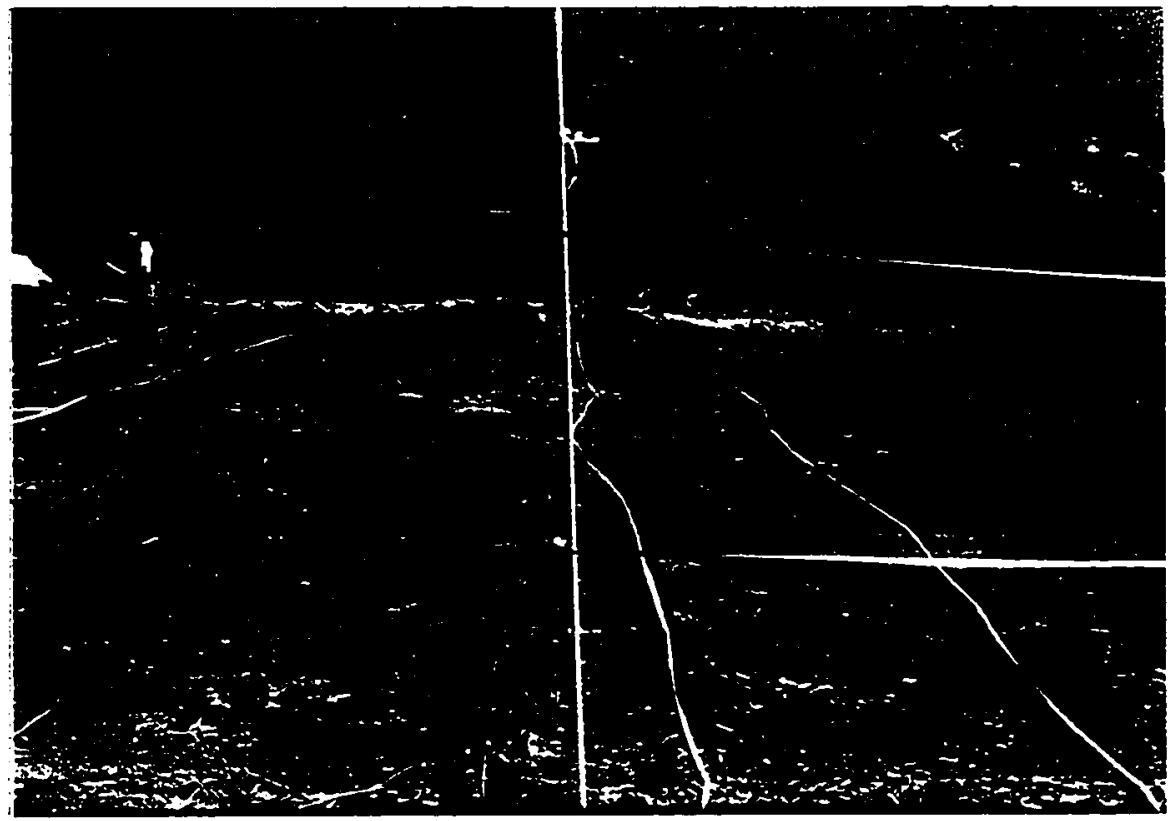

Figure 12. Photograph showing the granitic study area with fencing and flagging, which were installed to prevent motorcycle usage during the periods between tests.

- On each of the trails, riders rode upslope only (Figure 13). It is believed that the greatest amount of soil erosion occurs during upslope 
riding resulting from the acceleration required to maneuver upslope. The riders returned to the test trail entrance by a secondary trail. On each trail after 25, 75, and 175 (combined total) motorcycle passes over the trail, the microprofile was remeasured. To insure that the correct number of passes were made on each trail for each trial, a specific member of the survey team was designated to count the number of passes on each trail.

- The data from the various profiles were entered into a computer via spreadsheet. Microprofiles were developed, and the differences between successive profiles were determined.

- Through computer manipulations, the changes in profile geometry were determined. Estimates of the volume of materials detached from the ground surface, and thus positioned to be easily removed by slope wash and rainfall activity, were established. 


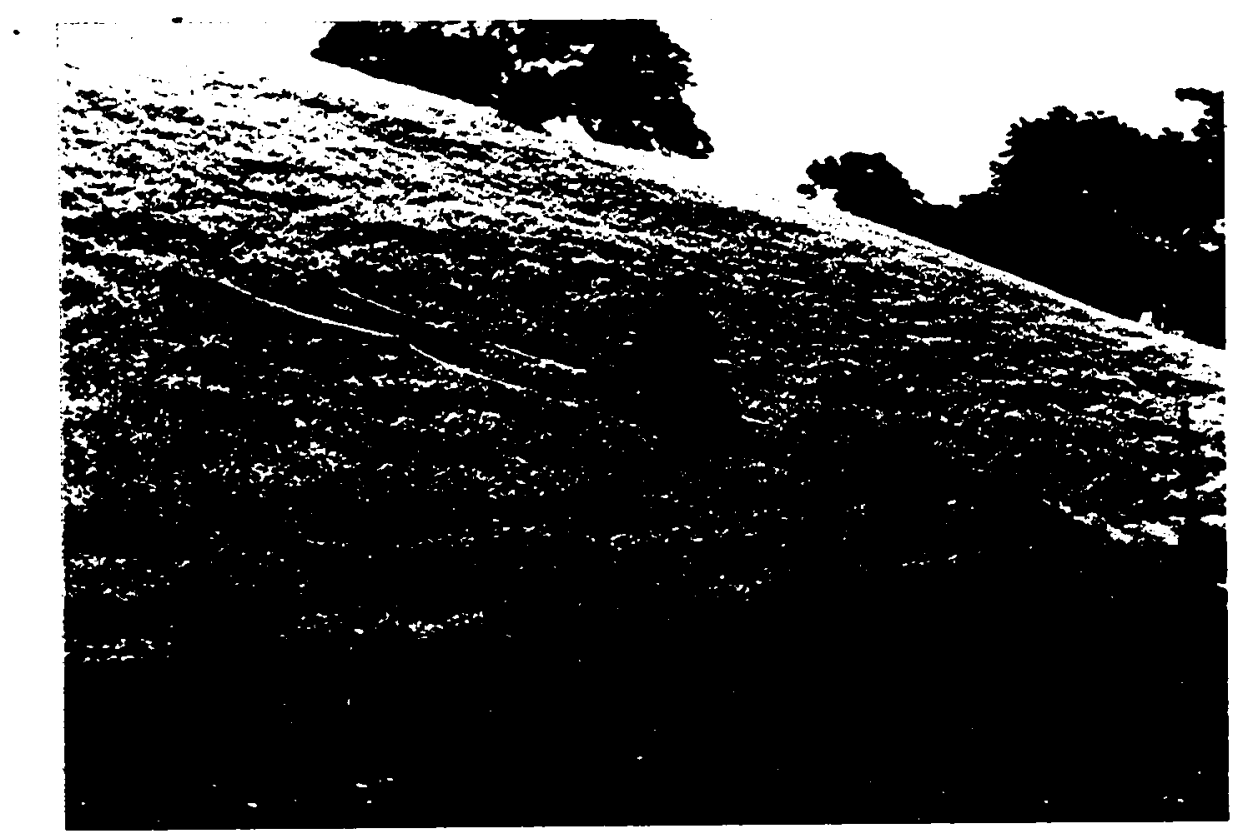

Figure 13. Photograph showing a motorcyclist riding upslope during one of the trials in the sedimentary area. 
RESULTS

Utilizing the procedures described, 246 microprofiles were recorded during the study: 138 microprofiles were measured in the sedimentary area and 112 microprofiles were measured in the igneous area. Approximately 7,000 individual data points were recorded and analyzed for this study. For example, at the microprofile nearest the base of the slope (Profile 3 ) of Lane 1 in the sedimentary area, measurements were obtained on 13 occasions (including the baseline measurement), each representing a single microprofile measurement, from up to 25 locations along the microprofile. A total of 317 data points were recorded at this profile. (Each lane had 3 microprofile locations. There were a total of 24 microprofile locations between the sedimentary and granitic areas.) A tabulation of the displacements from the original baseline for each run measured at each microprofile is included in Appendix A.

Data points for each specified distance from the reference stake (i.e., the same map position along the microprofile) were compared for each set of passes on the hillslope. The lowest data point (i.e., the location of the lowest surface for a given map position), representing the greatest amount of detached soil, was utilized for the total 
displacement along each microprofile. The graphical

representations of the greatest amount of detached soil for each microprofile are included on Figures 14 through 21 and in Appendix $B$.

Most of the data points indicating surface location were located within 0.3 feet of the original baseline surface. This was consistent with observations made in the field. Some of the data points plotted above the original baseline. These data points record accumulations of detached soil. Within the sedimentary unit, the microprofile nearest the base of the slope (Profile 3 ) typically exhibited the least amount of detached soil (Figures 14 through 17). This is not believed to be the area of the least detachment, but is believed to be instead the result of accumulation of sediments near the base of the hillslope. Visual observations made during the test indicated that the lower portion of the slope should have the greatest soil detachment; riders generally accelerate a greater amount at the base of the hillslope to begin their ascent than to continue their ascent at midslope. Additionally, excessive wheel spin producing a spray of soil behind the vehicle, also known as "rooster tails," is more common lower on the slope than higher. 


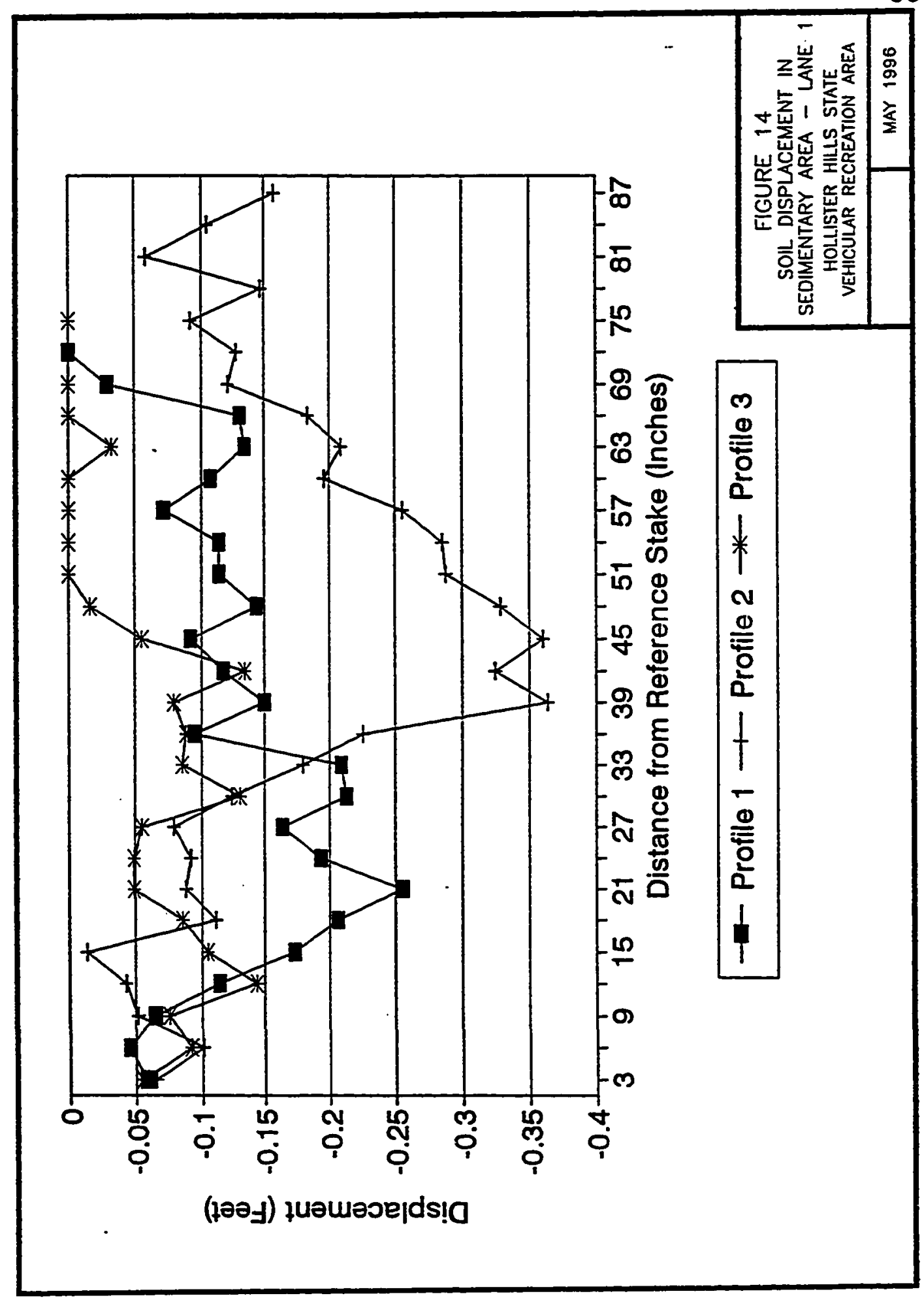




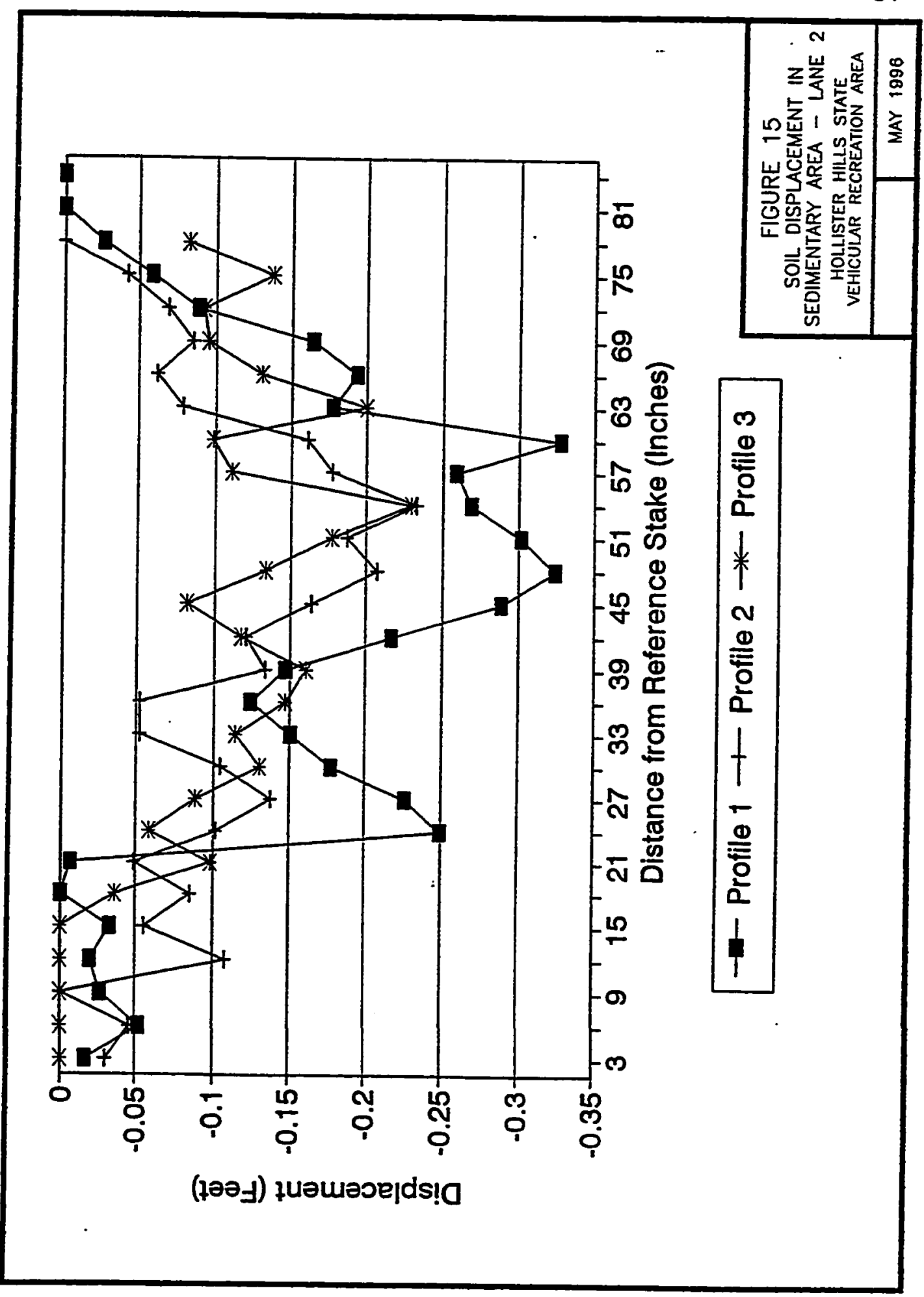




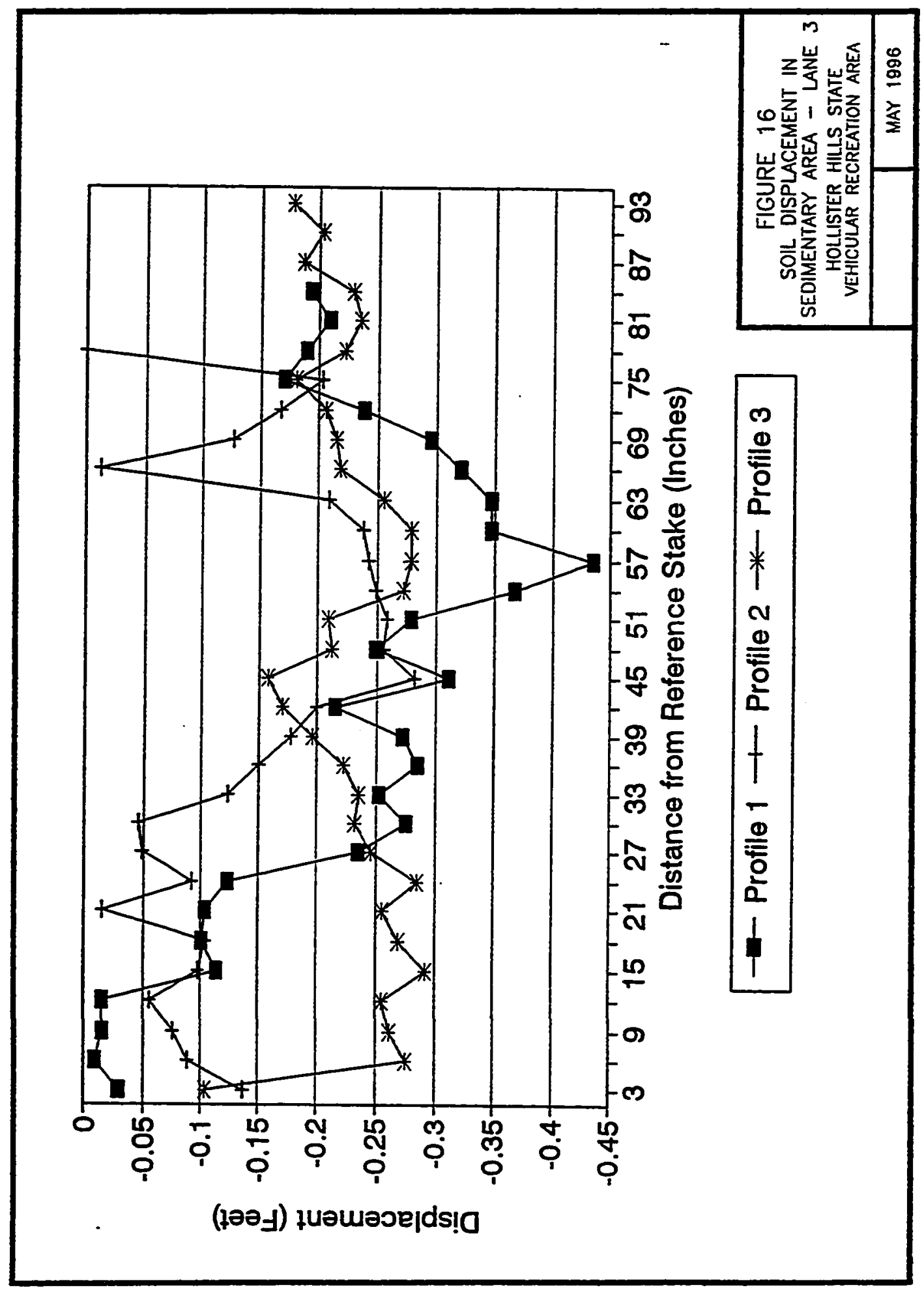




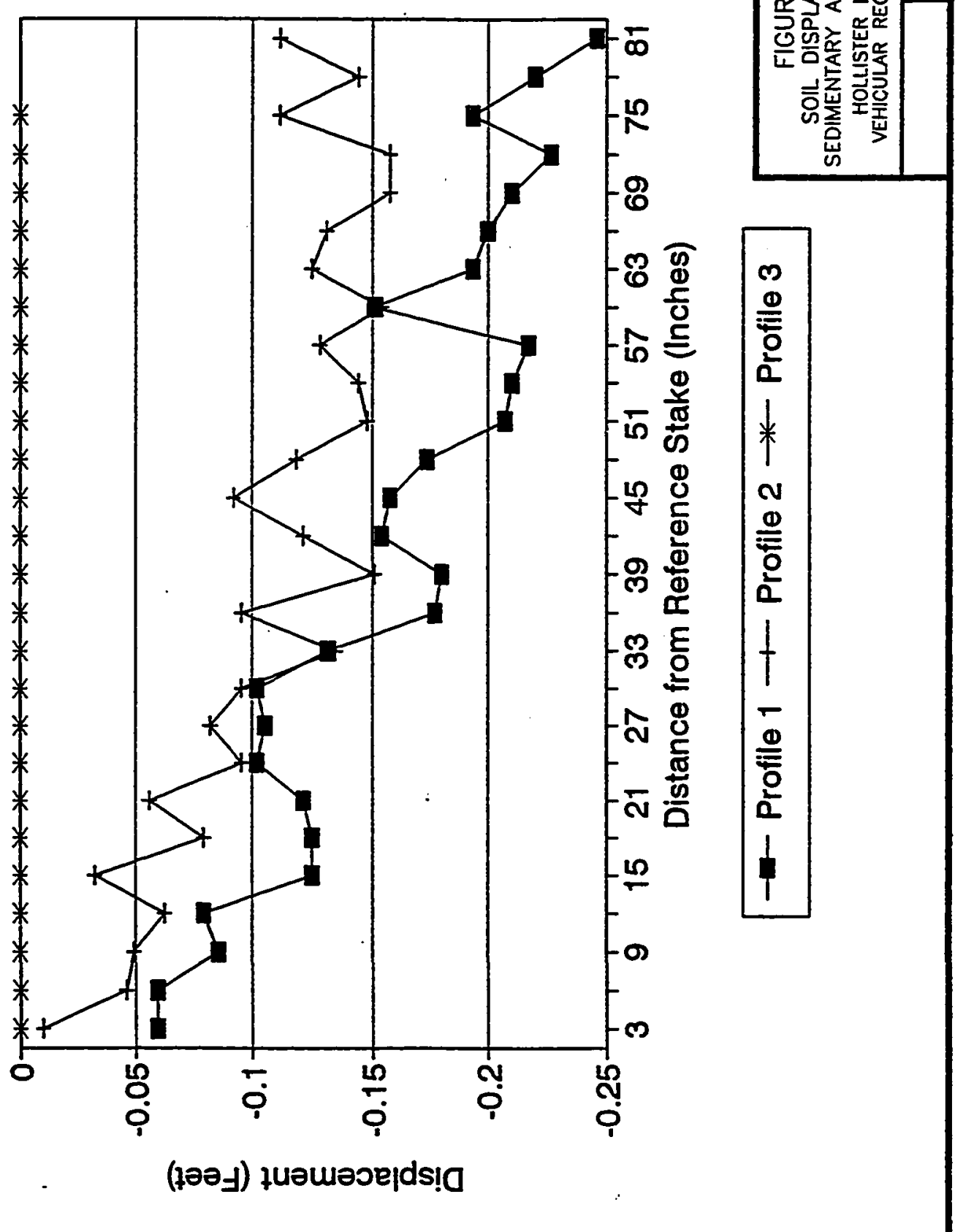


The measurements within the granitic unit did not exhibit any discernible pattern of soil accumulation with relation to the location of the microprofile on the hillslope. In Lane 1 of the granitic area, the greatest detachment of soil was at Profile 2 (the middle of the slope; Figure 18) while in Lane 2 the greatest detachment was at Profile 1 (the top of the slope; Figure 19), and in Lanes 3 and 4, the greatest detachment was at Profile (the bottom of the slope; Figures 20 and 21 ). It is believed that there was not the accumulation of soil at the lowest profile in the granitic area such as occurred at the sedimentary study area because of the grade of the slope; the sedimentary trial area had a steeper slope than the granitic area (see Figure 3 and 4 on pages 5 and 6 , respectively), thereby creating a condition where downward movement of the detached soil was more likely. 


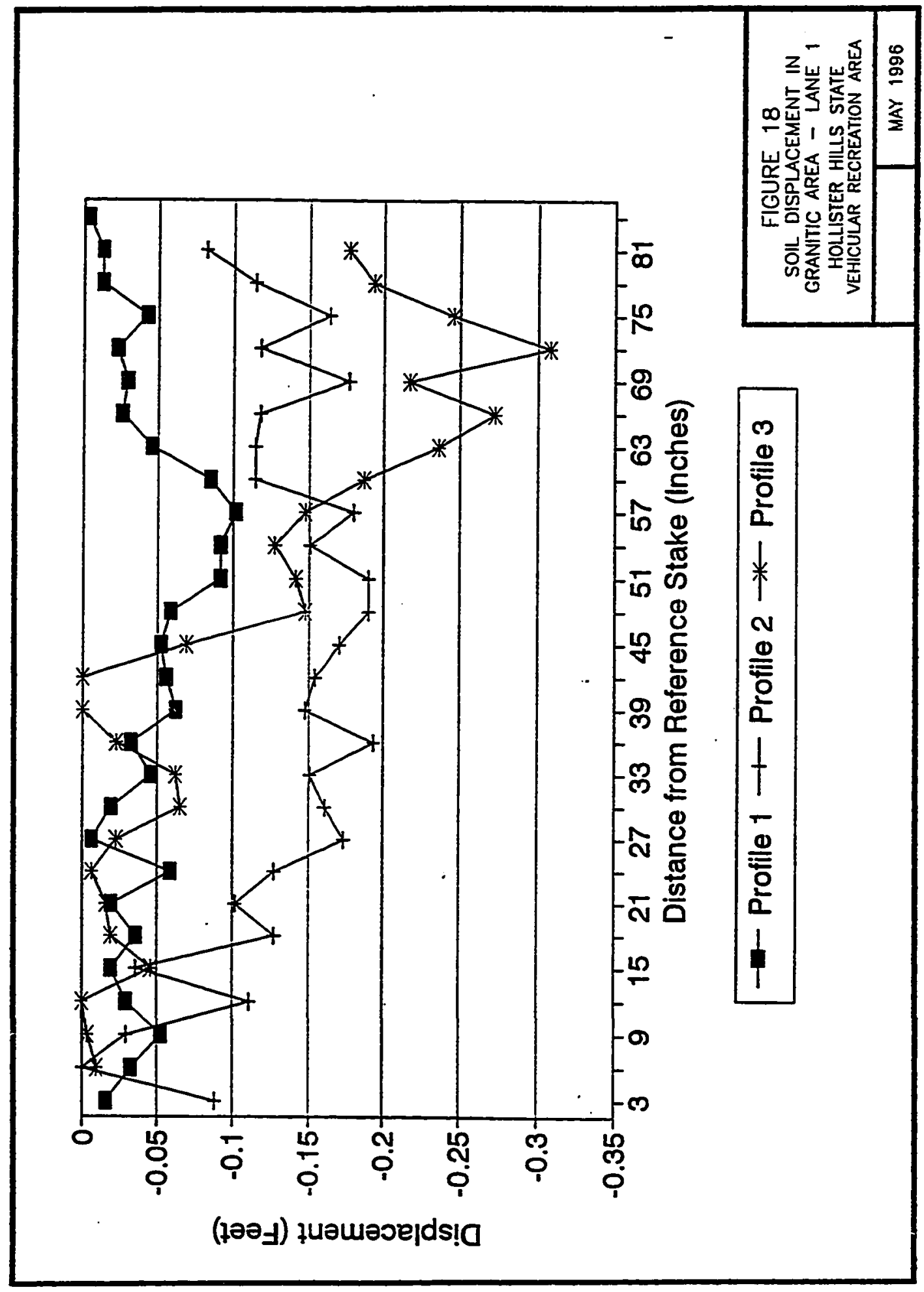




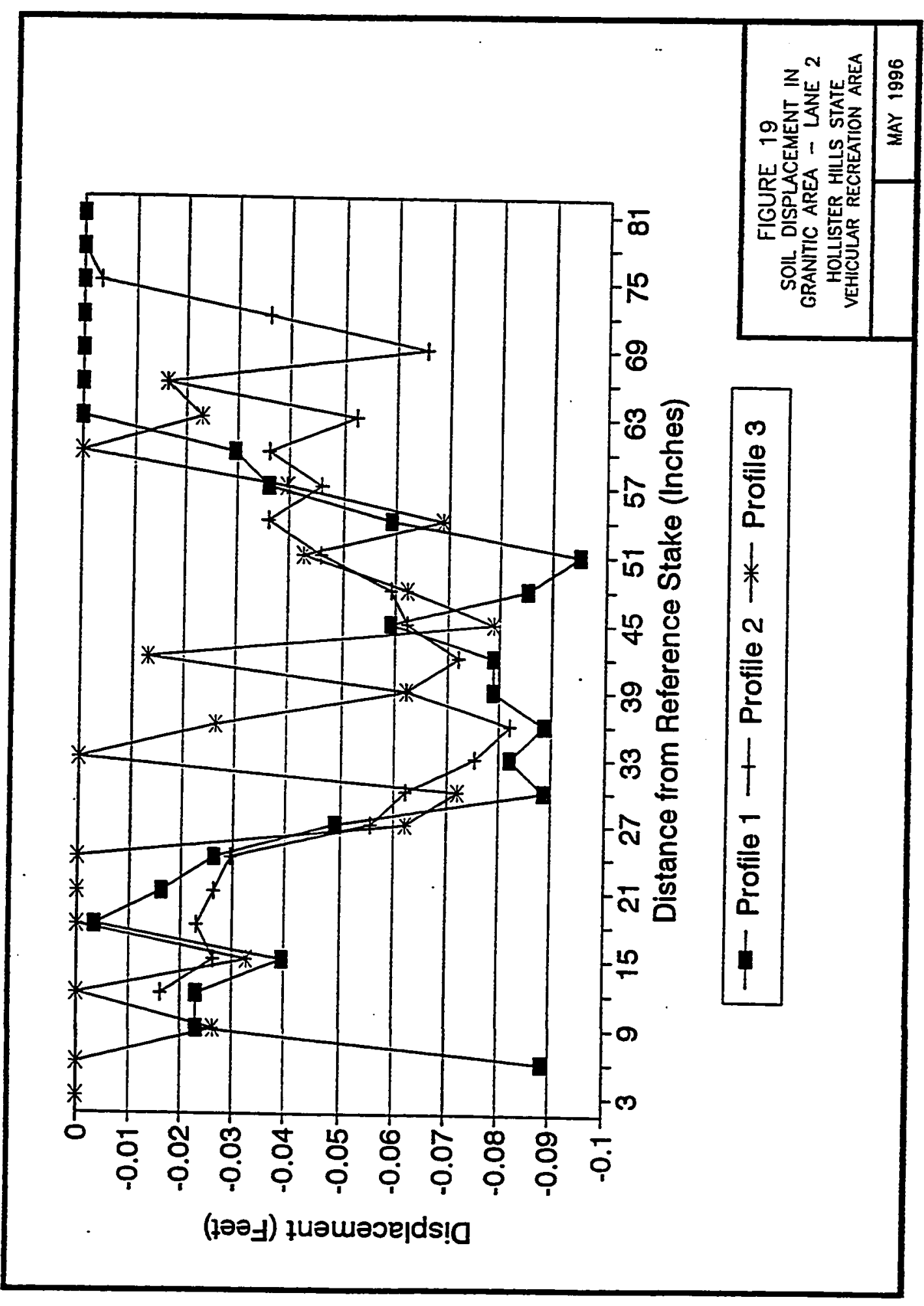




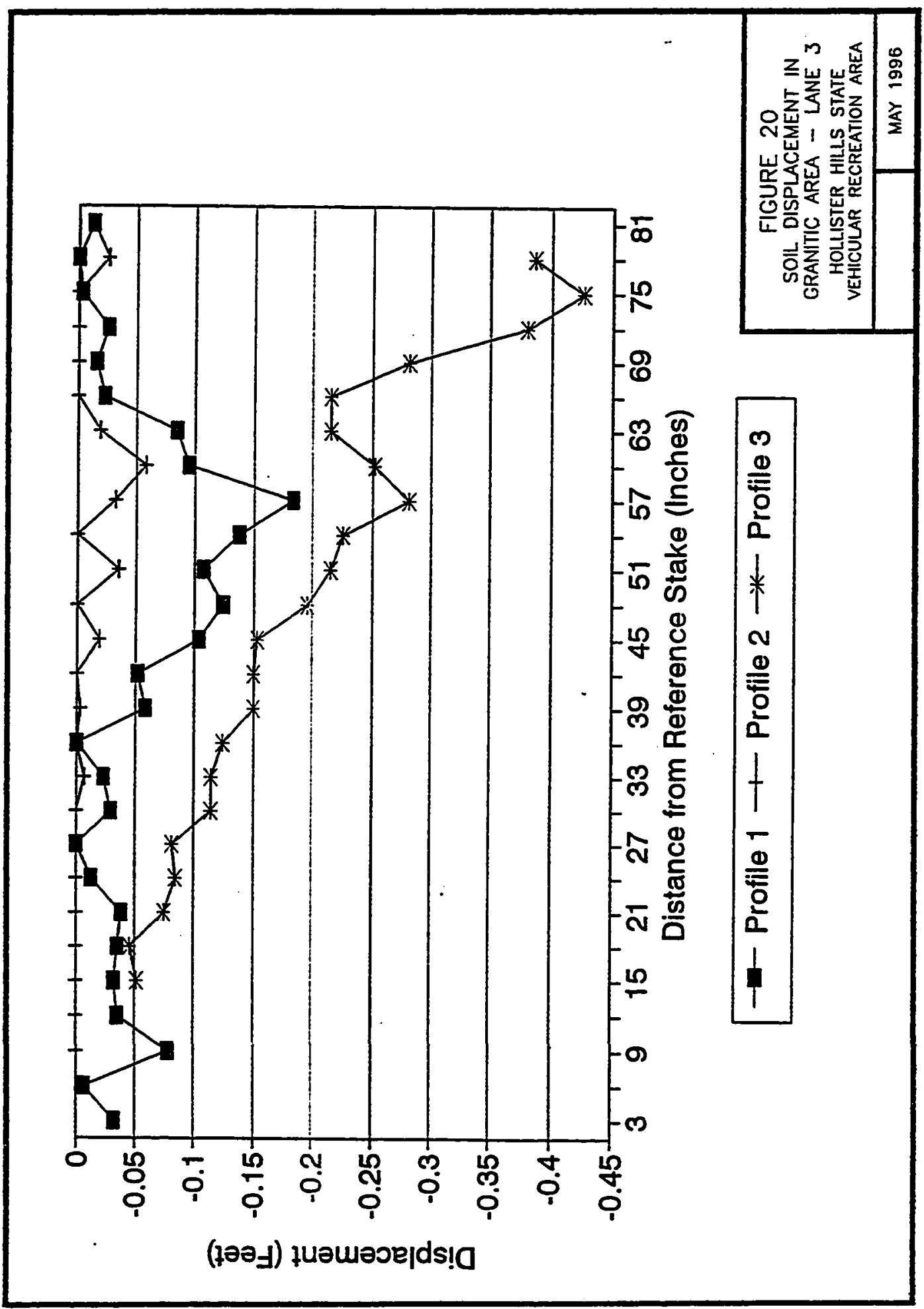




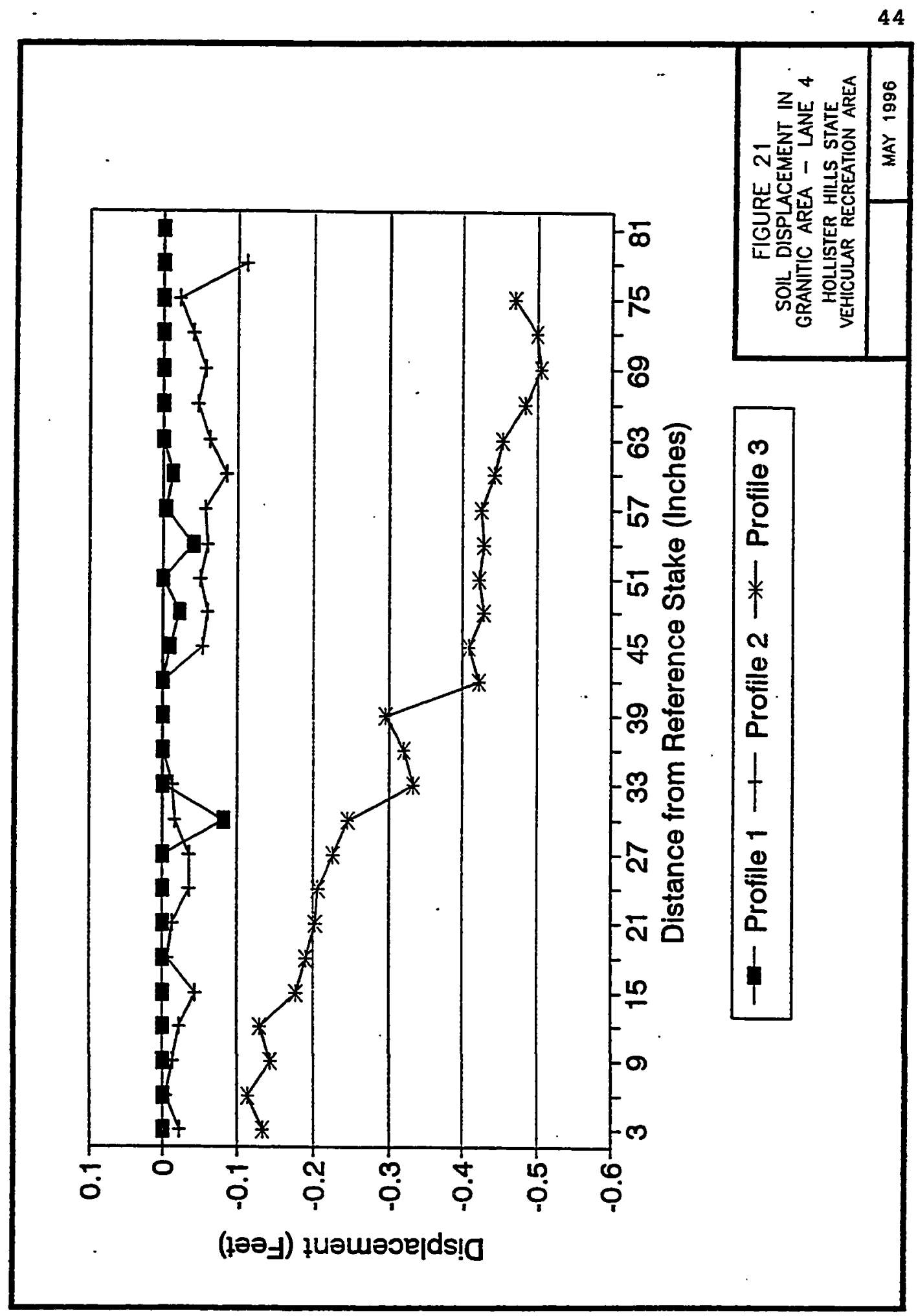


The total displacements for each microprofile (i.e., the sum of the greatest displacement at each data point along the microprofile) were multiplied by 0.25 foot/foot to give the total volume of soil detached per foot of trail for that microprofile. The 0.25 foot is the spacing between individual data points as measured along the soil bridge ( 0.25 foot intervals, or every 3 inches). The volumes for the three microprofiles located in each lane were averaged to obtain the average amount of soil displacement for the entire lane. This figure was then divided by the average width of the lane to obtain the average amount of detached soil per square foot of trail. The following amounts of detached soil were obtained for each rock-type:

\section{Granitic Soils}

- $\quad>250 \mathrm{cc}=0.455$ cubic foot of detached soil per linear foot of trail $\left(\mathrm{ft}^{3} / \mathrm{ft}\right)$ and $0.0674 \mathrm{cubic}$ foot of detached soil per square foot of trail $\left(f t^{3} / f t^{2}\right)$;

-250 cc 2 -stroke $=0.575 \mathrm{ft}^{3} / \mathrm{ft}$ and $0.0885 \mathrm{ft}^{3} / \mathrm{ft}^{2}$ 
- 250 cc 4-stroke $=0.167 \mathrm{ft}^{3} / \mathrm{ft}$ and $0.0278 \mathrm{ft}^{3} / \mathrm{ft}^{2} ;$ and

- $\quad<250 \mathrm{cc}=0.365 \mathrm{ft}^{3} / \mathrm{ft}$ and $0.0600 \mathrm{ft}^{3} / \mathrm{ft}^{2}$

\section{Sedimentary soils}

$-\quad>250 \mathrm{cc}=0.57 \mathrm{ft}^{3} / \mathrm{ft}$ and $0.0876 \mathrm{ft}^{3} / \mathrm{ft}^{2}$;

$-250 \mathrm{cc} 2-$ stroke $=1.05 \mathrm{ft}^{3} / \mathrm{ft} 0.150 \mathrm{ft}^{3} / \mathrm{ft}$

- $250 \mathrm{cc} 4$-stroke $=0.563 \mathrm{ft}^{3} / \mathrm{ft}$ and $0.0834 \mathrm{ft}^{3} / \mathrm{ft}^{2}$; and

$-\quad<250 \mathrm{cc}=0.44 \mathrm{ft}^{3} / \mathrm{ft}$ and $0.066 \mathrm{ft}^{3} / \mathrm{ft}^{2}$. 


\section{CONCLUSIONS}

On both the sedimentary and igneous type soils, the 250 cc 2-stroke motorcycles displaced a larger amount of soil than any of the other motorcycle sizes. The smallest motorcycles ( $250 \mathrm{cc}$ ) caused the least amount of soil displacement in the sedimentary units and the next smallest amount of soil displacement in the igneous-derived soils. Based on the collective results of the soil displacements, the $250 \mathrm{cc}$ 2-stroke motorcycles detach the greatest amount of soil and the smaller motorcycles (<250 cc) detach the least amount of soil. The other two sizes of motorcycles, $>250 \mathrm{cc}$ and $250 \mathrm{cc}$ 4-stroke, detach an intermediate amount of soil. As all values for volume of material detached are based upon averages, the absolute values may change from site to site but the relative ranking of motorcycle size impact should remain the same. Based on the results of the study, soil type does not appear to affect the relative soil displacement rates of the motorcycles of differing sizes.

These data indicate that the amount of detached soil is related to the motorcycle size. Additional study of the mechanical characteristics of individual sizes of motorcycles and style of riding would probably provide additional information on rates of mechanical erosion. 


\section{REFERENCES CITED}

American Society for Testing and Materials, 1990, Test Method for Infiltration Rate of Soils in Field Using Double-Ring Infiltrometers (serial designation D 338575), 6 p.

Anders, F.J., and Leatherman, S.P., 1987, Disturbance of beach sediment by off-road vehicles: Environment, Geology, Water, and Science, v. 9, no. 3, p. 183-189.

Bennett, S., 1973, A trail rider's guide to the environment: The American Motorcycle Association, $60 \mathrm{p}$.

California Department of State Parks and Recreation, Division of off-Highway Motor Vehicle Recreation, 1994, A 1993-1194 report, off-highway vehicle (OHV) recreation's $\$ 3$ billion economic impact in California \& a profile of otv users: a family affair, 26 p.

California, Off-Highway Motor Vehicle Recreation Commission, 1992, Biennial report on the status of OHV recreation in California, 1989-90 and 1990-91, $136 \mathrm{p}$.

DeMets, C., Gordon, R.G., Stein, S., and Argus, D.F., 1987, A revised estimate of Pacific-North American motion and implications for western North American plate boundary zone tectonics: Geophysical Research Letters, v. 14, no. 9, p. 911-914.

Fetter, C.พ. Jr., 1980, Applied Hydrogeology. Columbus, Ohio: Charles E. Merrill Publishing Company, 488 p.

Harden, D.R., 1991, Sediment basin studies 1990, Hollister Hills State Vehicular Recreation Area, unpublished report, p. 2 .

Lisowski, M., and Prescott, W.H., 1981, Short-range distance measurements along the San Andreas fault system in central California, 1975 to 1979: Seismological Society of America Bulletin, v. 71, no. 5, p. 16071624 .

Rogers, T.H., 1993, Geology of the Hollister and San Felipe quadrangles, San Benito, Santa Clara, and Monterey Counties, California: California Department of Conservation, Division of Mines and Geology open-File Report 93-01, 26 p. 
Ross, D.C., 1972, Geologic map of the pre-Cenozoic basement rocks, Gabilan Range, Monterey and San Benito Counties: United States Geological Survey Miscellaneous Field Studies Map MF 357.

Schulz, S.S., Mavko, G.M., Burford, R.O., and Stuart, W.D., 1982, Long-term fault creep observations in central California: Journal of Geophysical Research, v. 87, no. B8, p. 6977-6982.

Sheridan, D., 1980, off-road vehicles on public lands. Council on Environmental Quality, Washington, D.C., 84 p.

Snyder, C.T., Frickel, D.G., Hadley, R.F., and Miller, R.F., 1976, Effects of off-road vehicle use on the hydrology and landscape of central and southern California: United States Geological Survey Water Resources Investigation 76-99, $30 \mathrm{p}$.

Steinbrugge, R.V., and Zacher, E.G., 1960, Creep on the San Andreas fault (California)-fault creep and property damage: Seismological Society of America Bulletin, v. 50, no. 3, p. 389-396.

United States Forest Service, 1988. Internal memorandum. 17 October 1988. Monitoring on-site soil loss from ORV trails (Bikes \& ATV'S).

1989. Internal memorandum. 27 December 1989. Monitoring soil disturbance on bike trails, Rowher Flat ORV area.

Wallace, R.E., ed., 1990, The San Andreas fault system, California: United States Geological Survey Professional Paper 1515, 283 p.

Webb, R.H., Ragland, H.C., Godwin, W.H., and Jenkins, D., 1978, Environmental effects of soil property changes with off-road vehicle use: Environmental Management, v. 2 , no. 3, 219-233. 
APPEIDIX A - SOIL DISPIACEMENT TABLES 


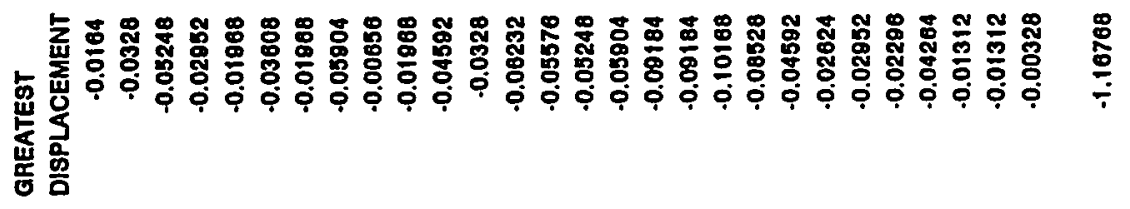

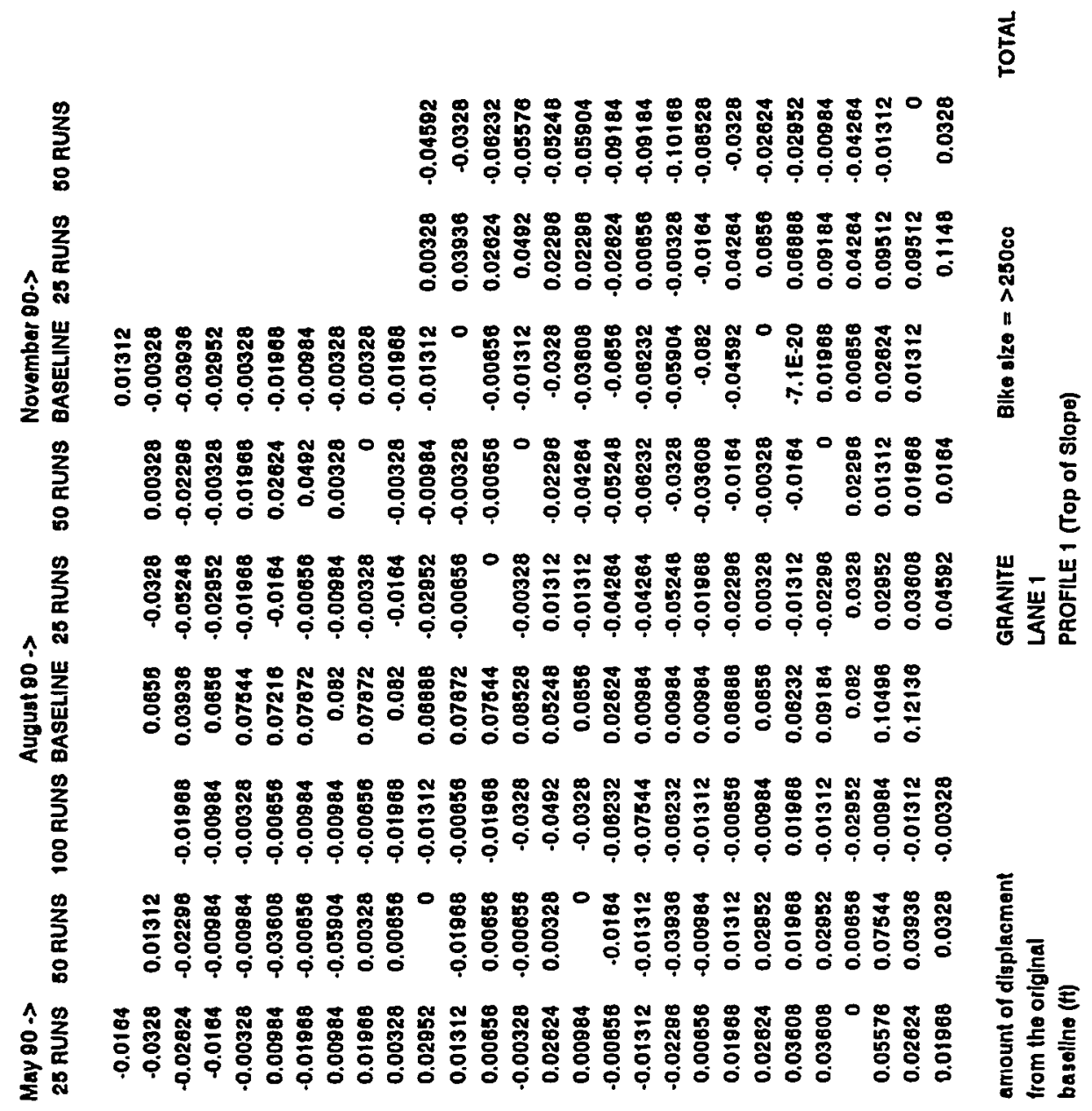

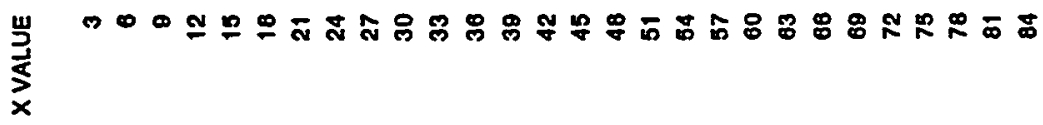




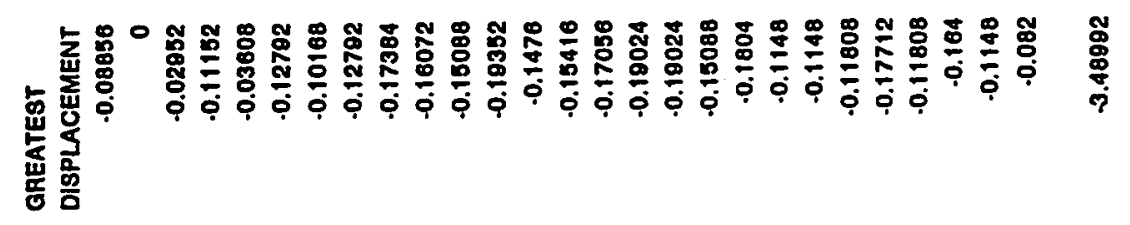

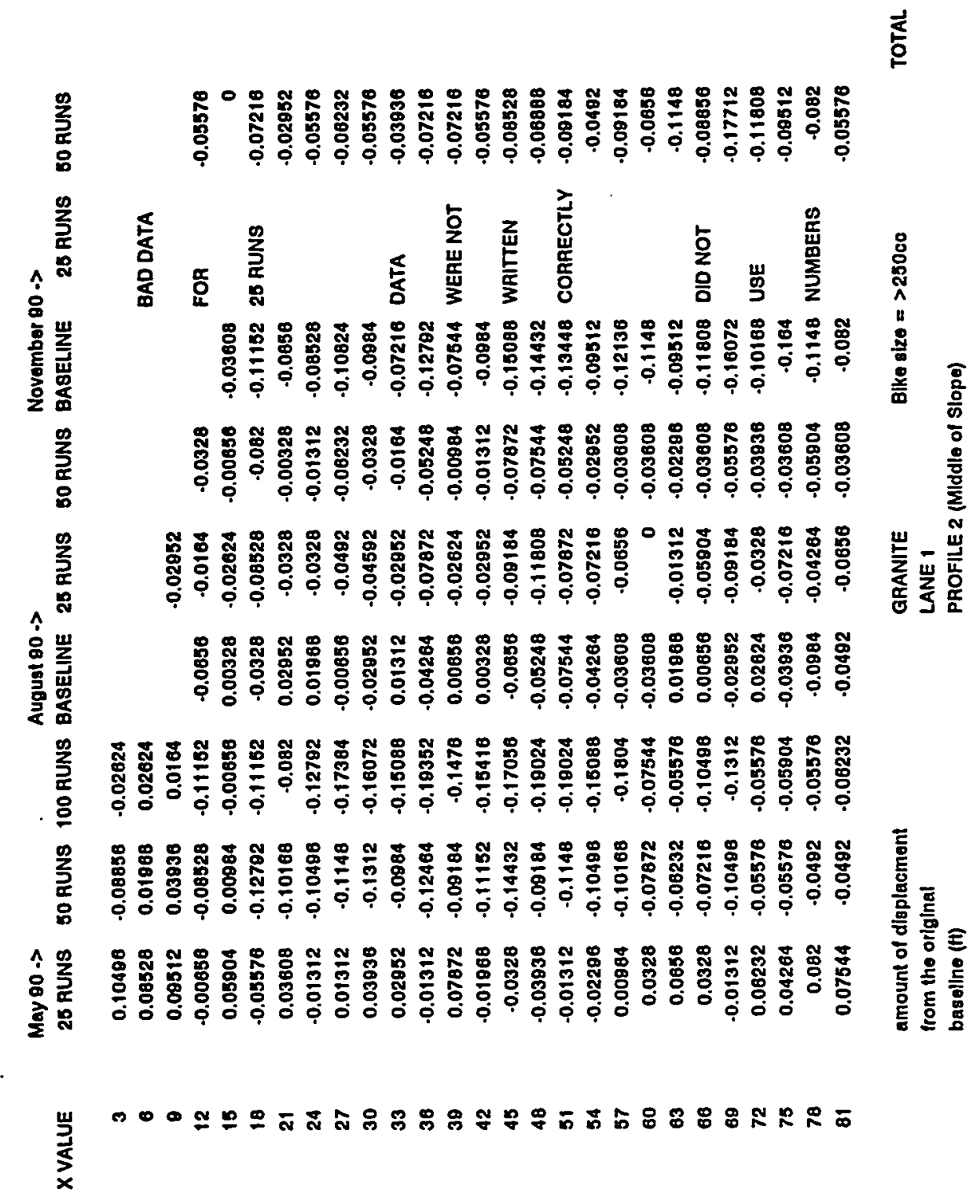




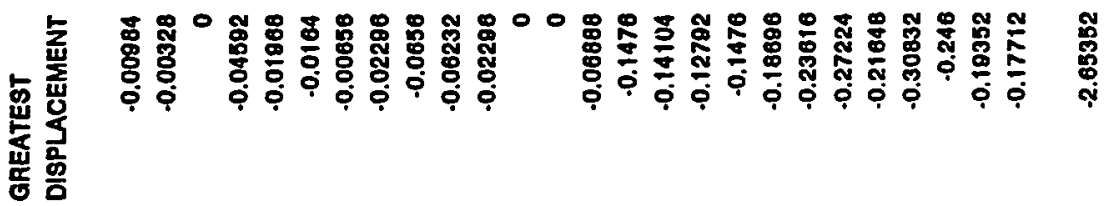

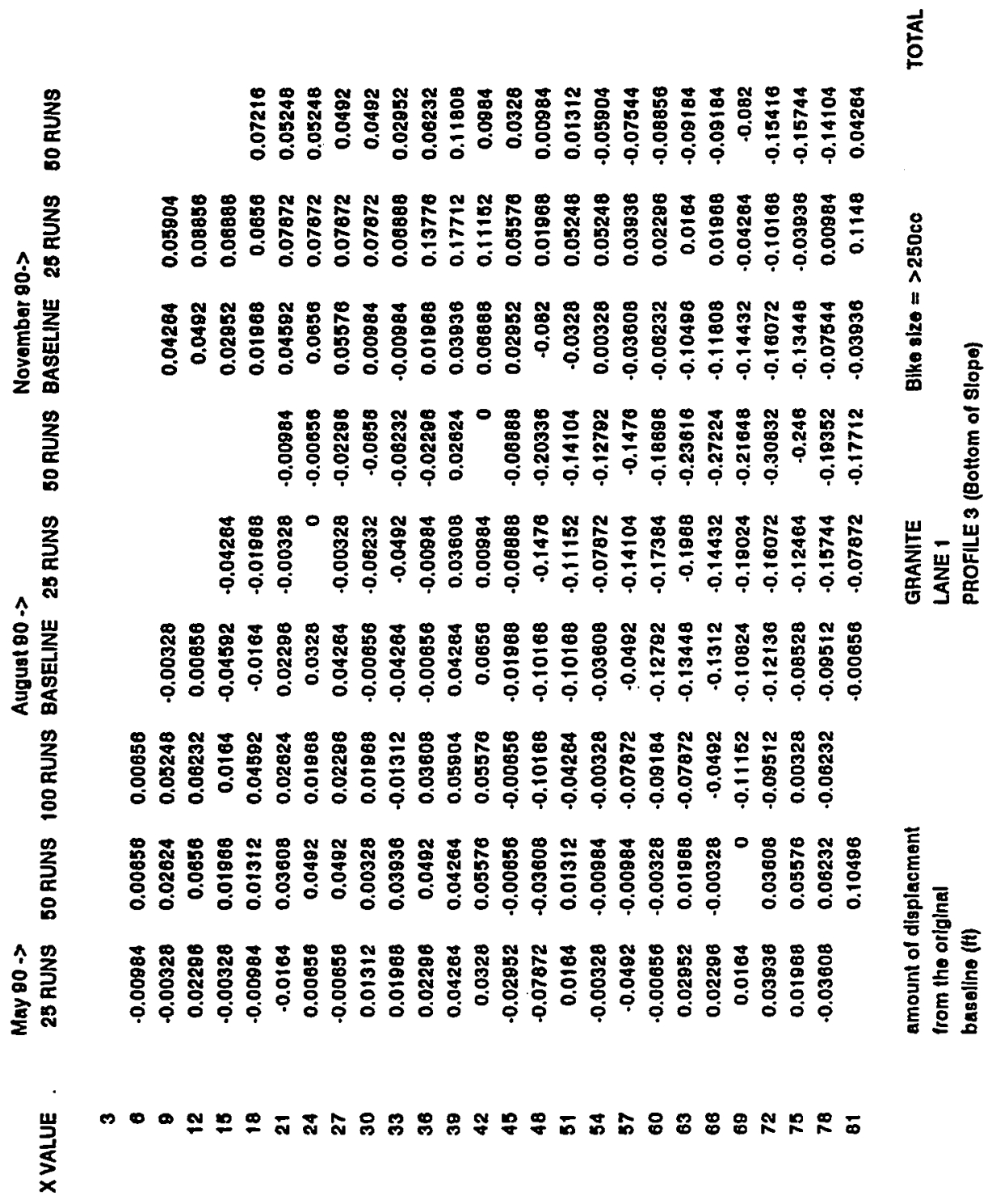




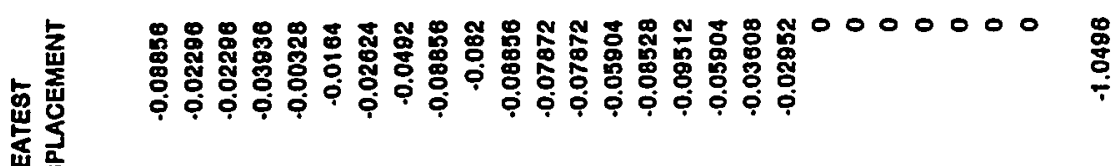

t

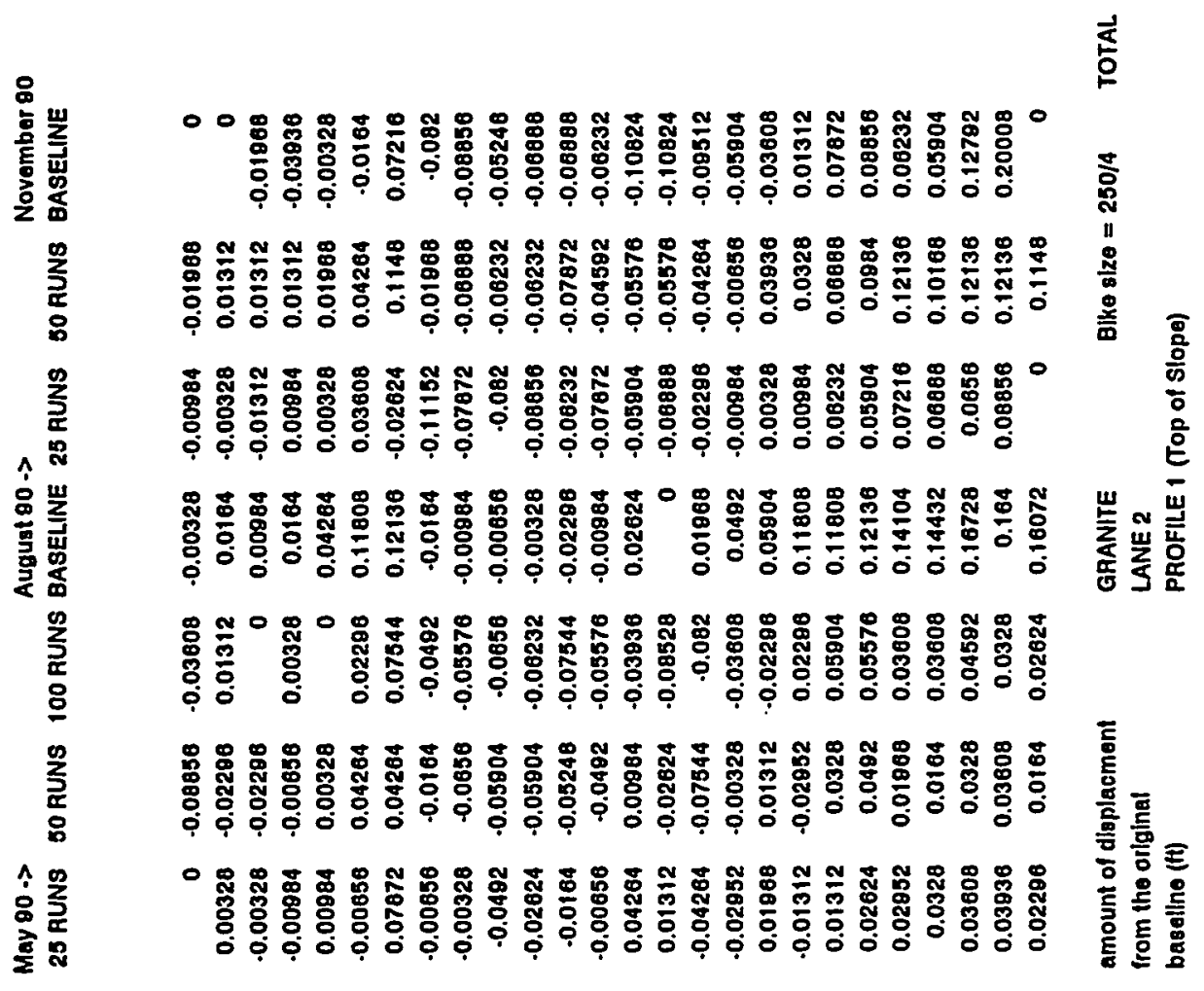

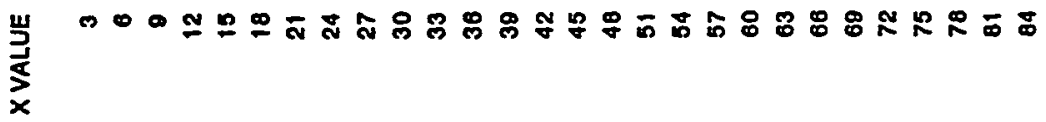




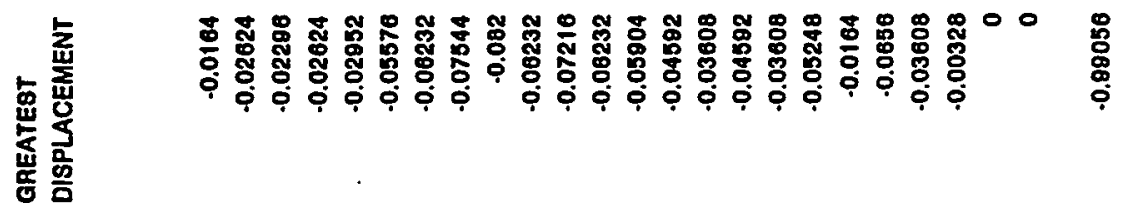
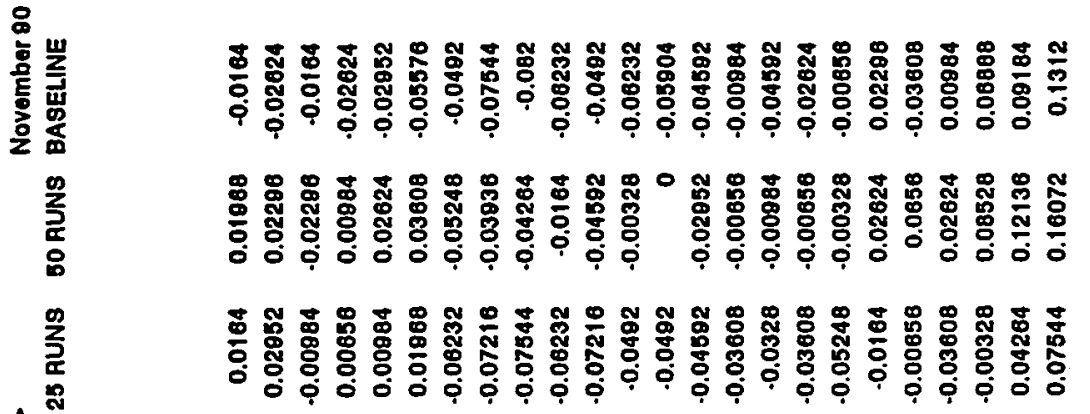

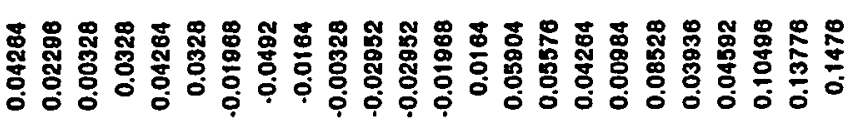

$\frac{3}{6}$ 


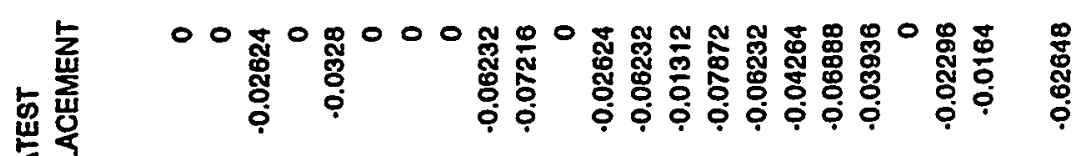

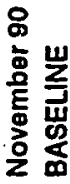

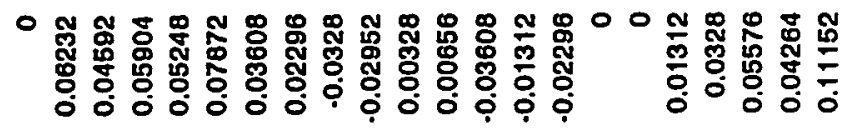

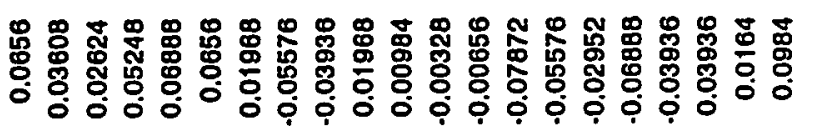

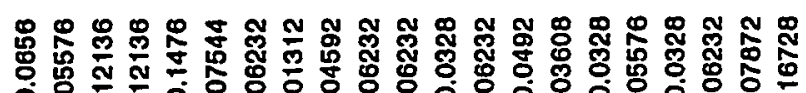

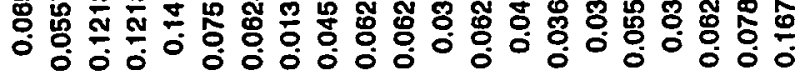

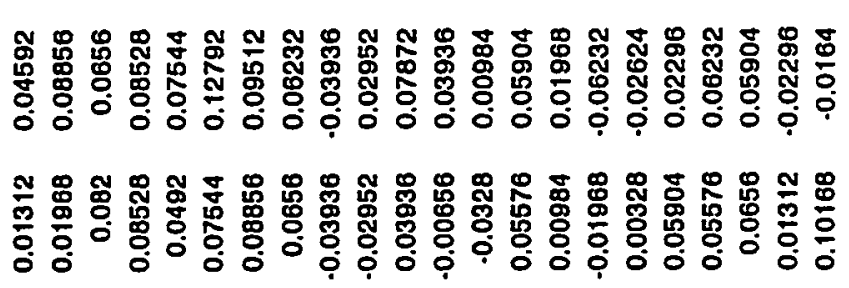

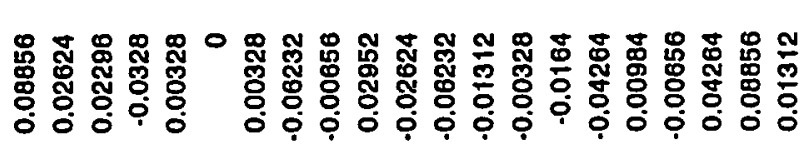

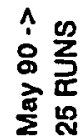
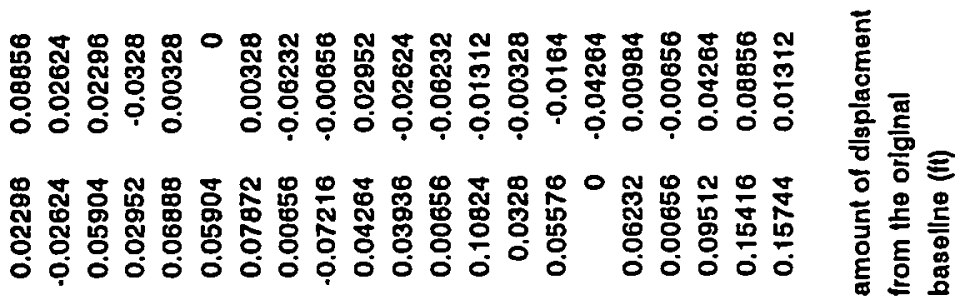

岂 


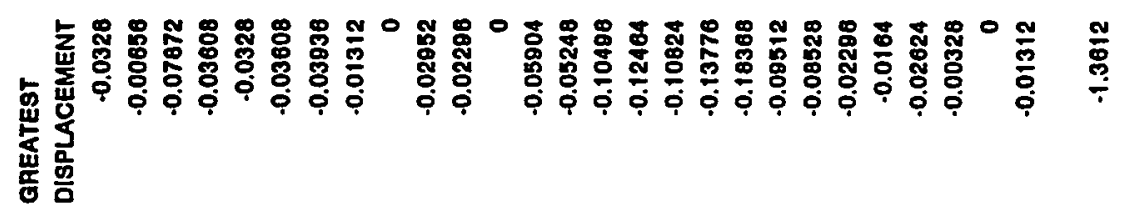

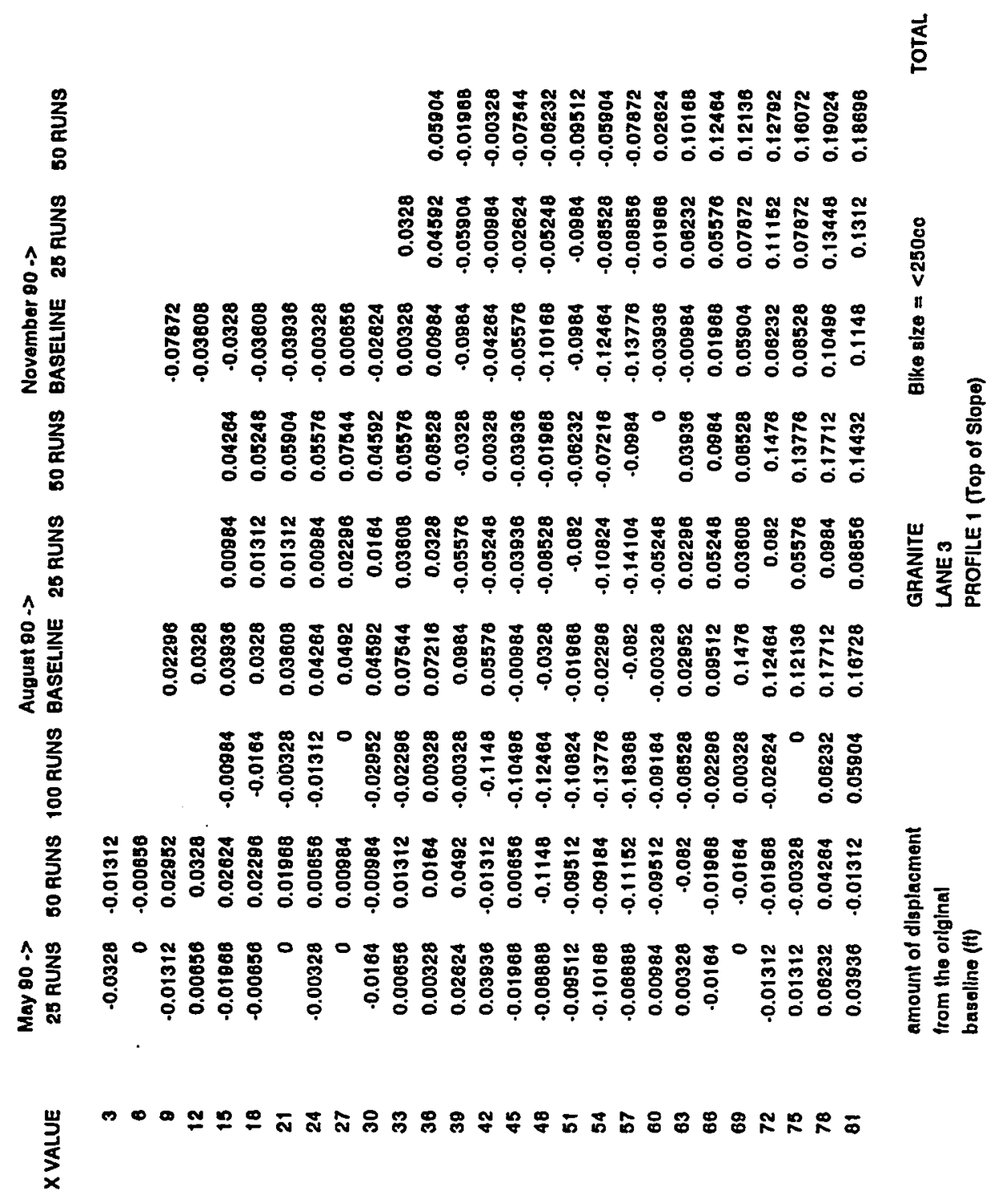




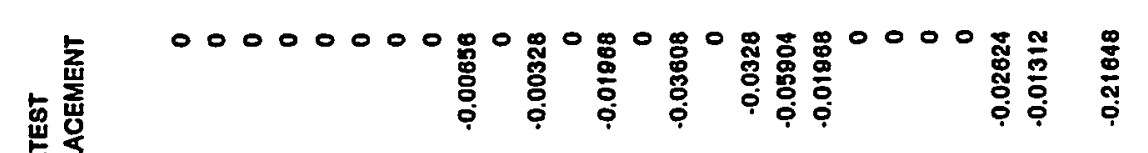

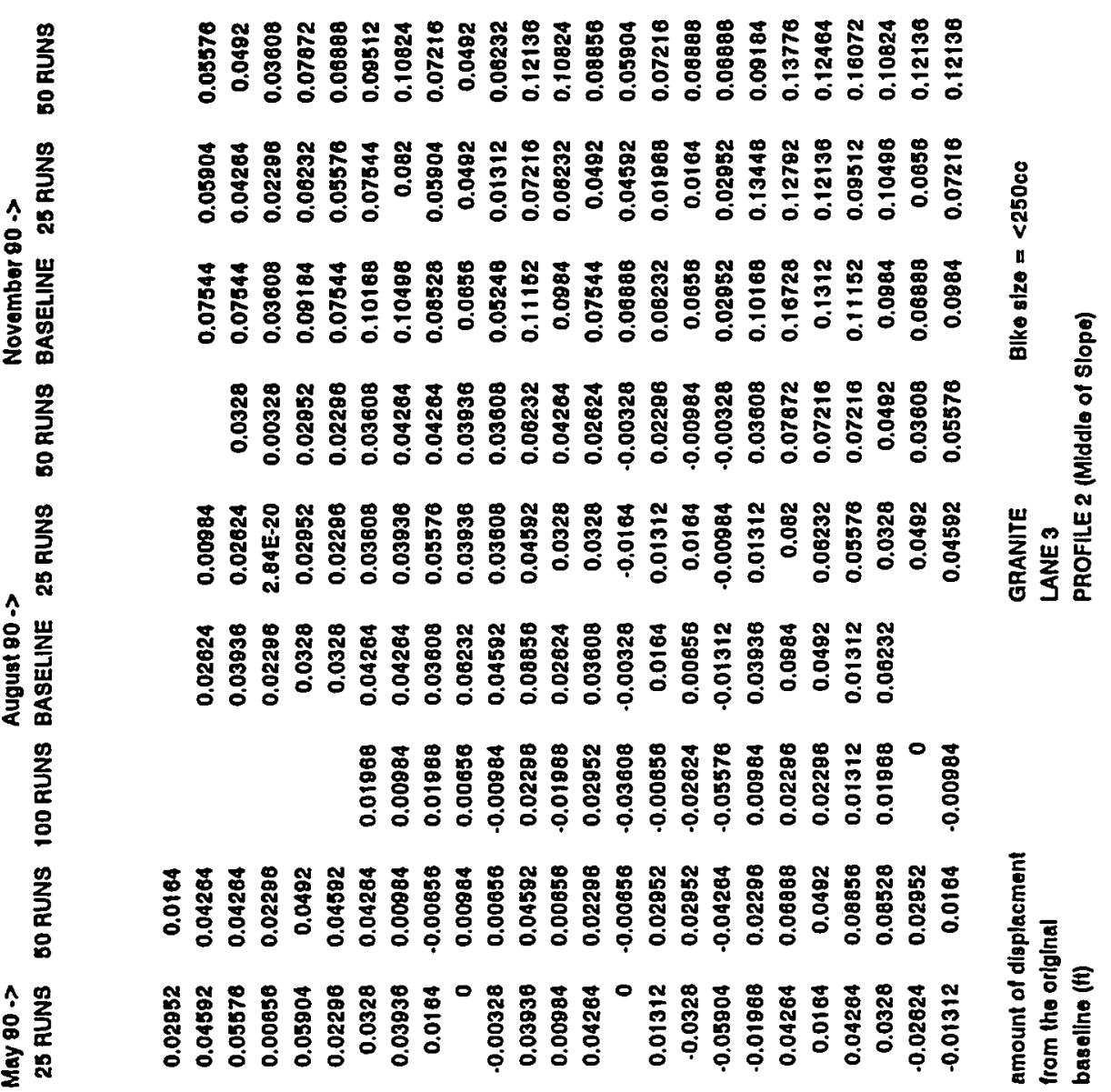

崖 


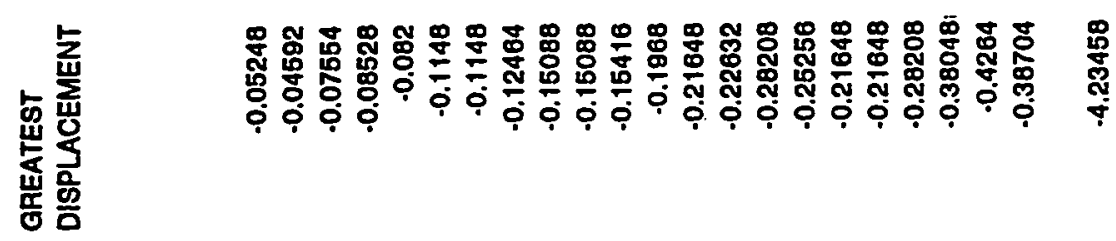

농

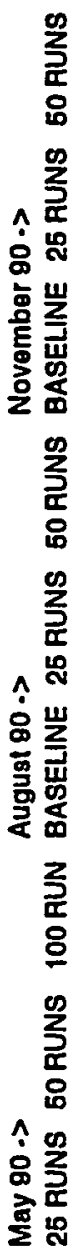

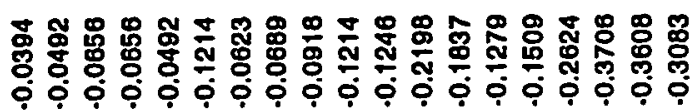

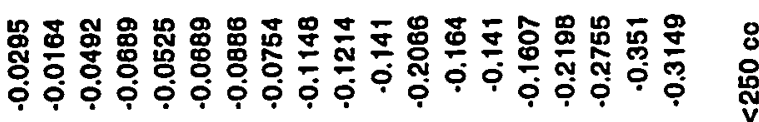

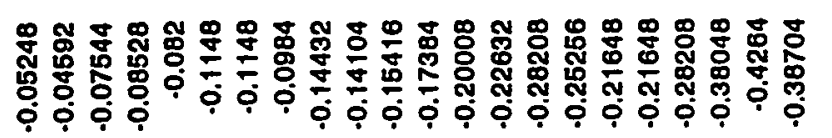

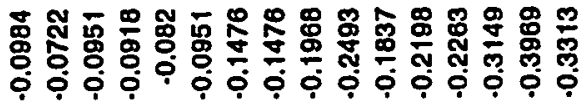

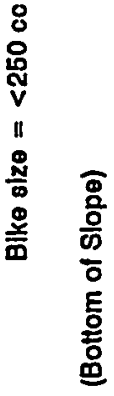

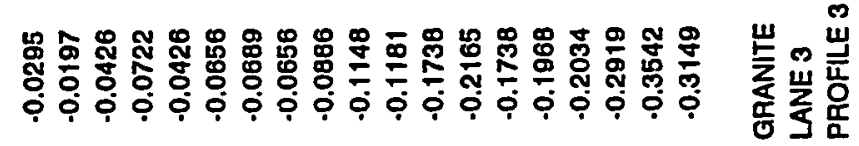

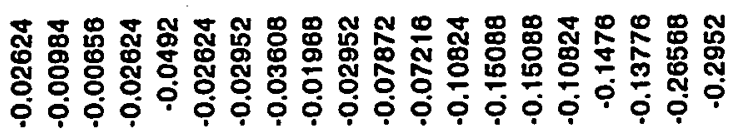

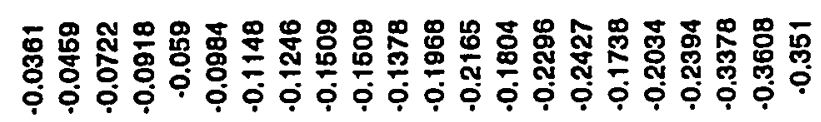

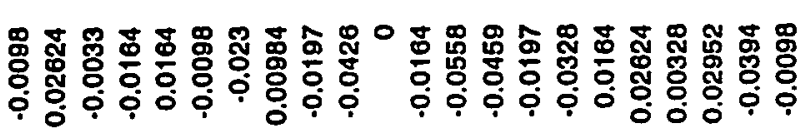

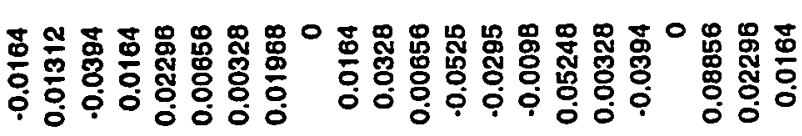

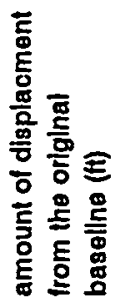
岂 


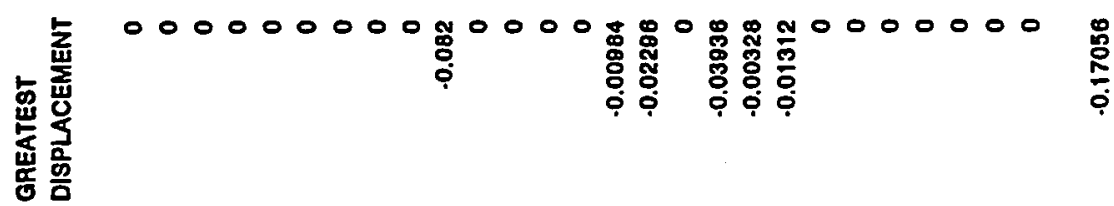

홍

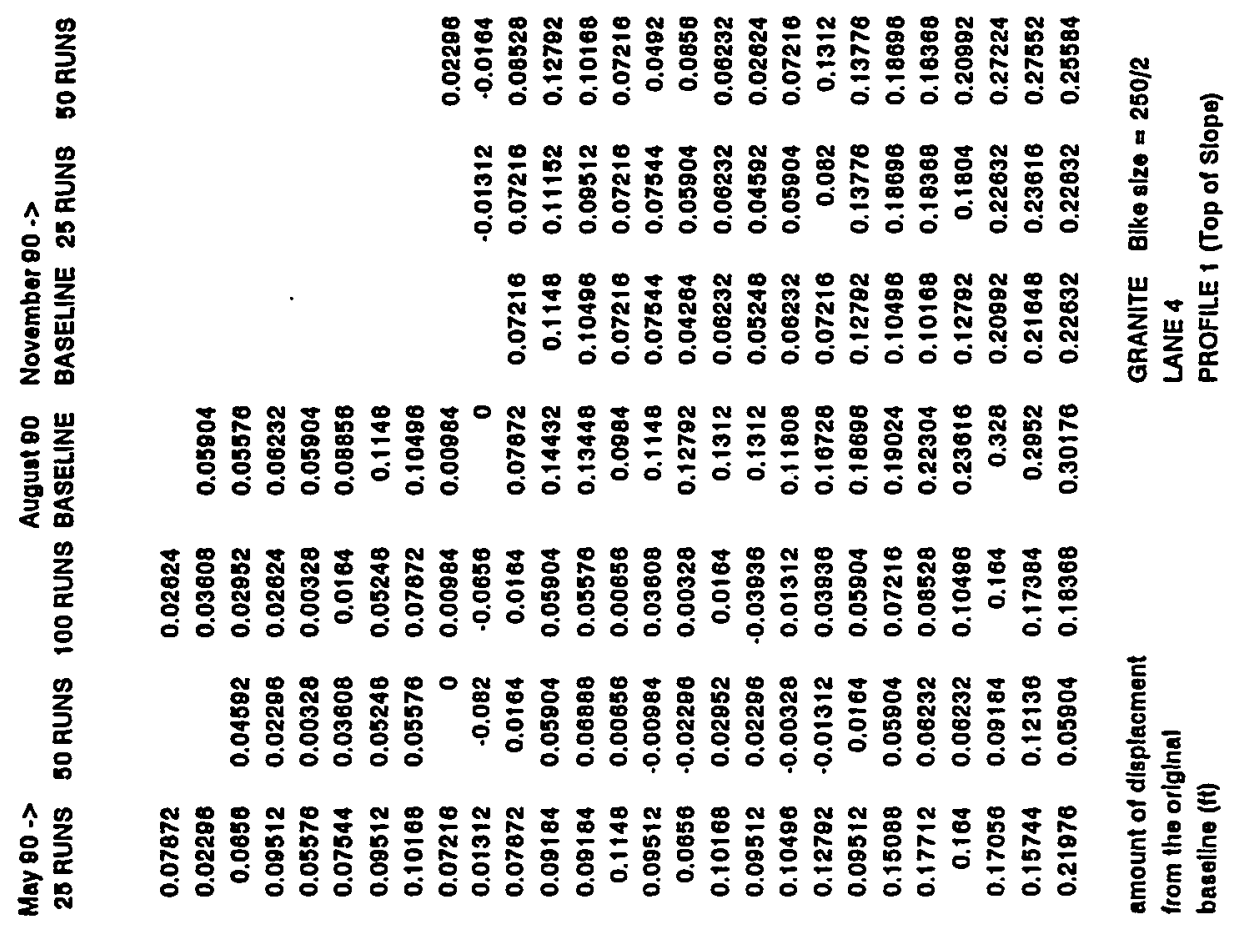

$\sum_{x}^{\frac{\omega}{5}}$ 


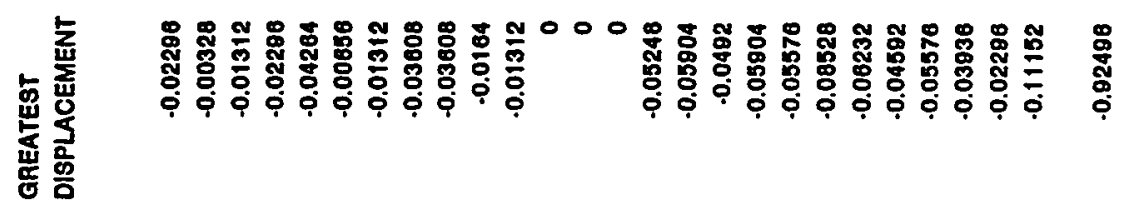

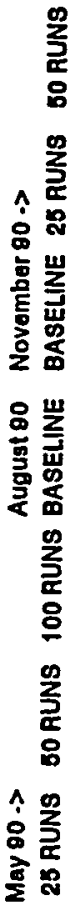

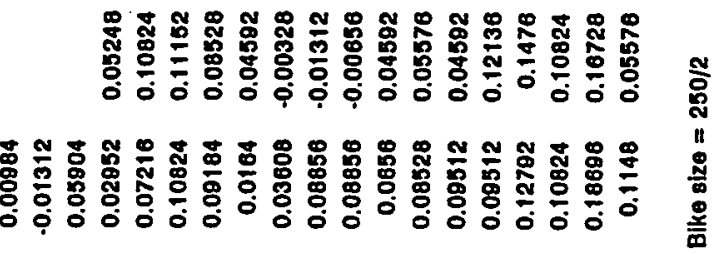

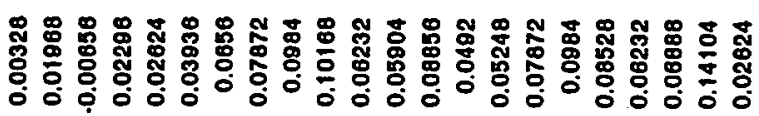

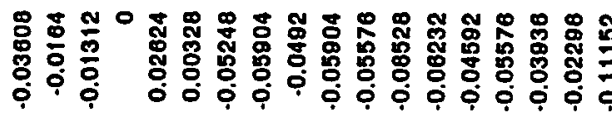

홍

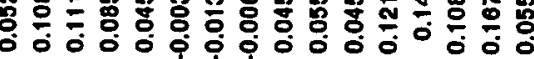

응

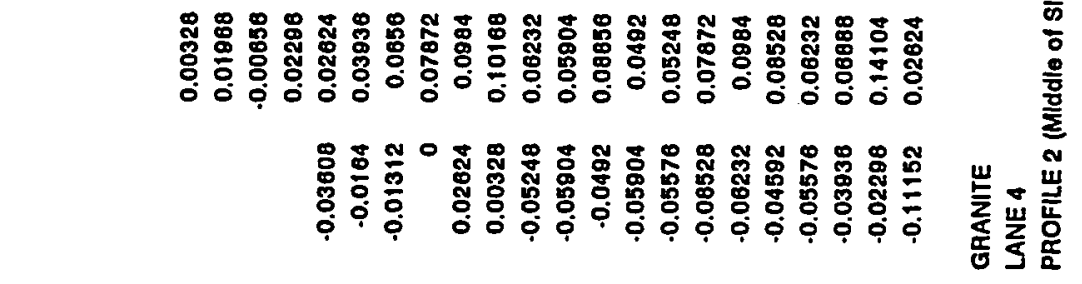

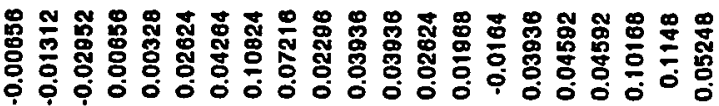

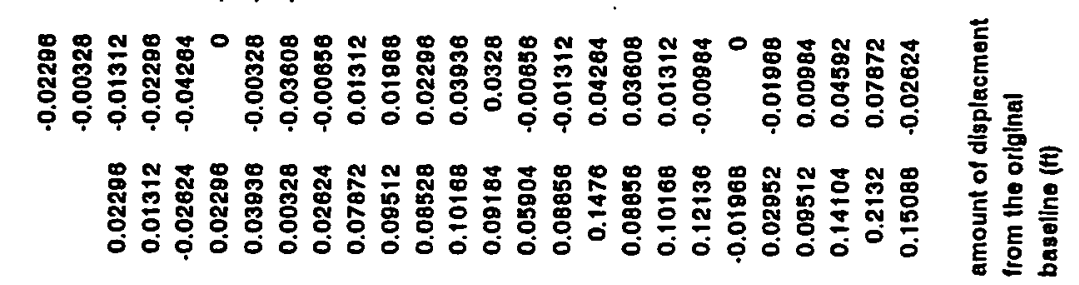

$\stackrel{\text { 岁 }}{\stackrel{\underline{⿱}}{x}}$

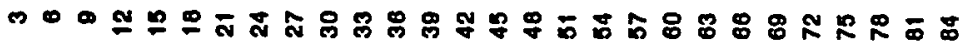




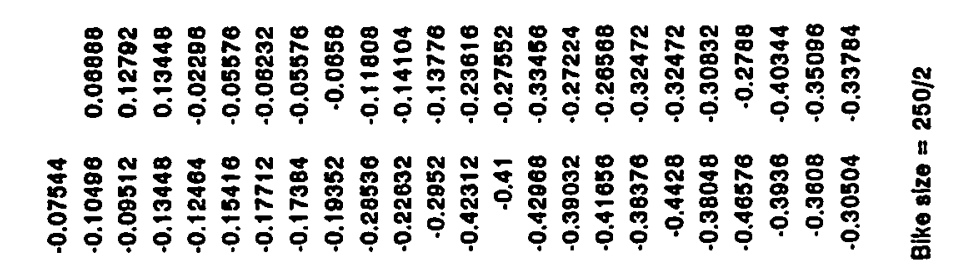

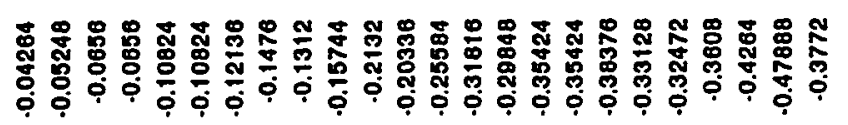

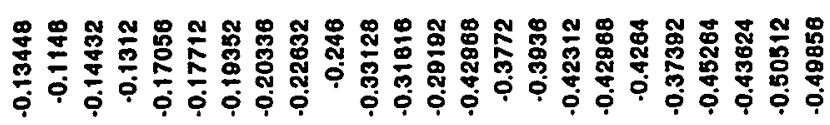

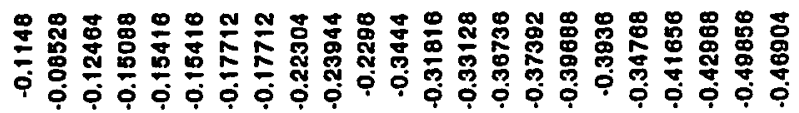

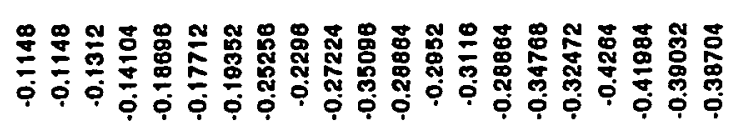

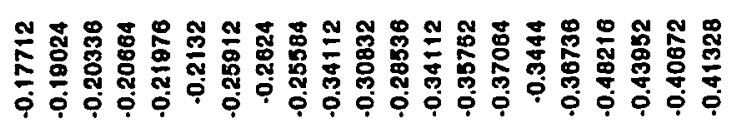

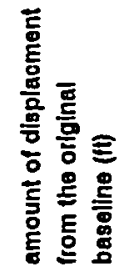




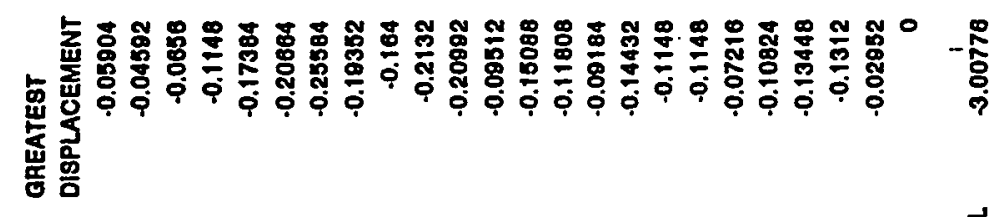

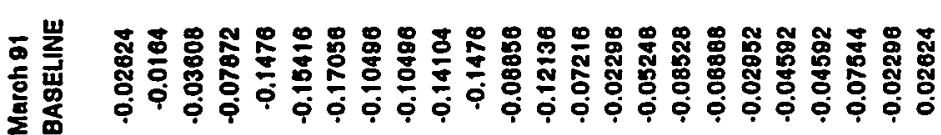

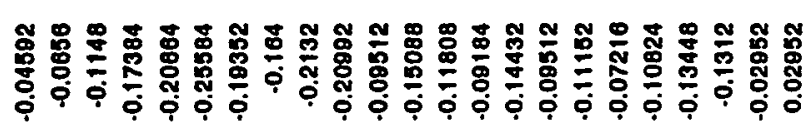

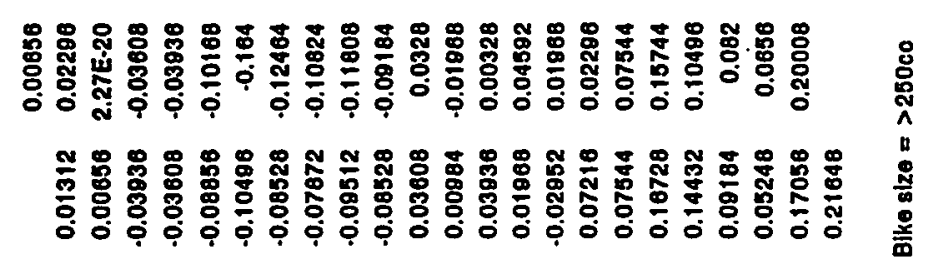

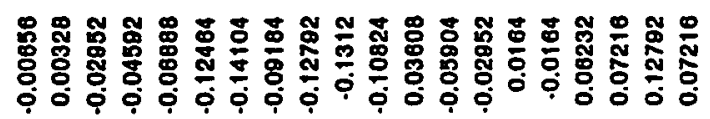

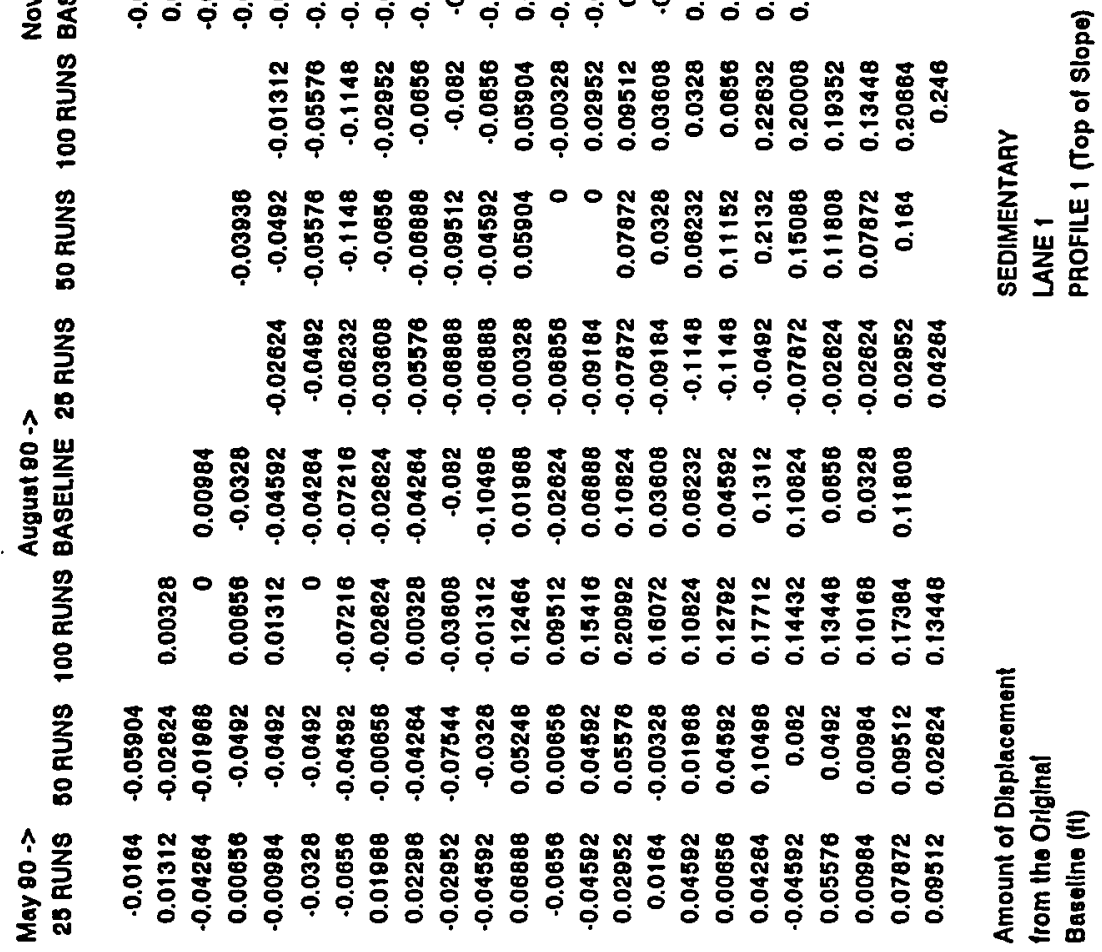

岁 


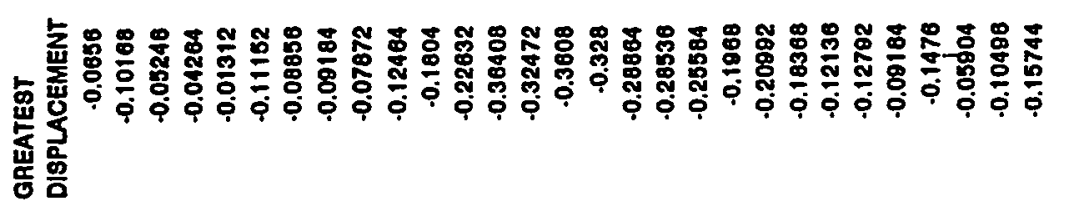

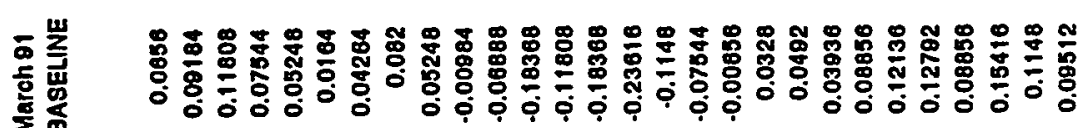

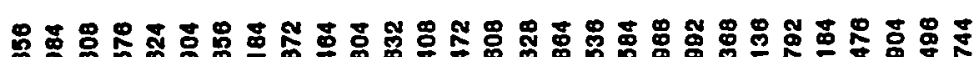

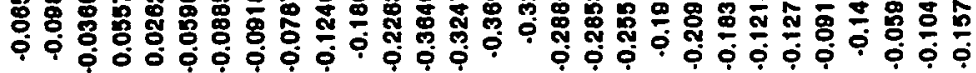

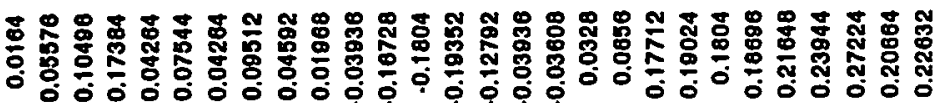

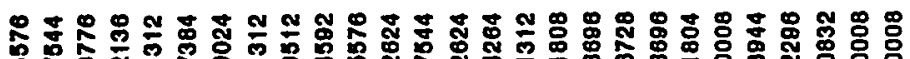

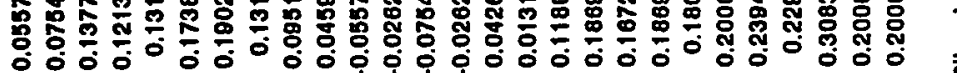

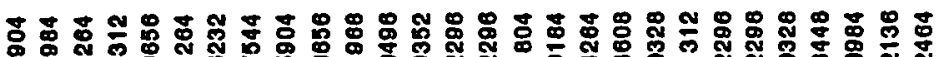

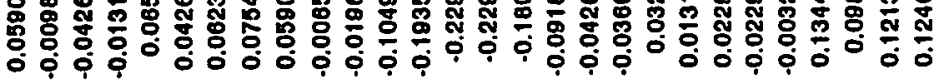

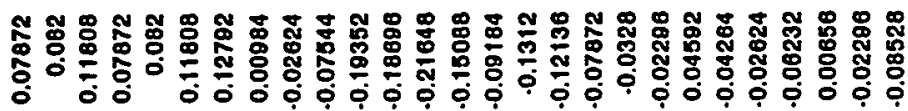

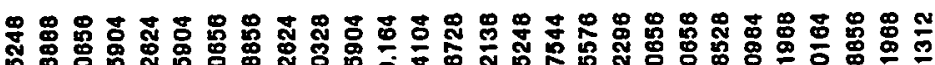

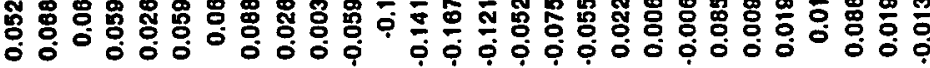

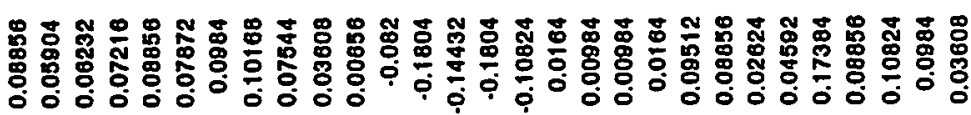

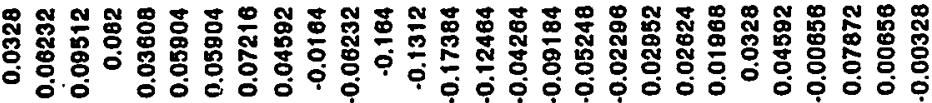

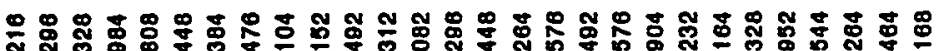

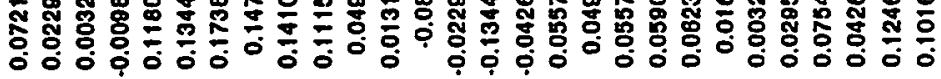

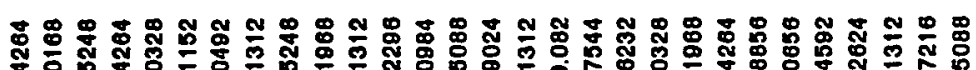

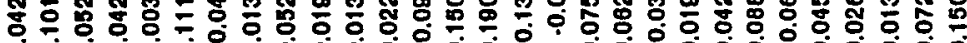

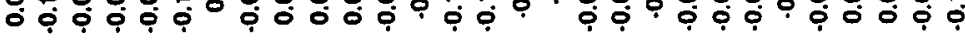
余罢

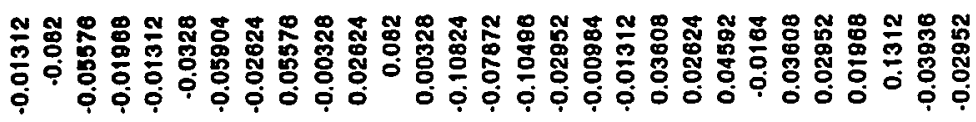




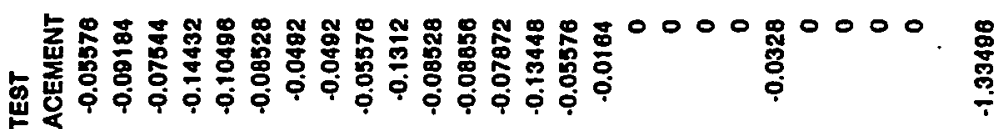

悹喜

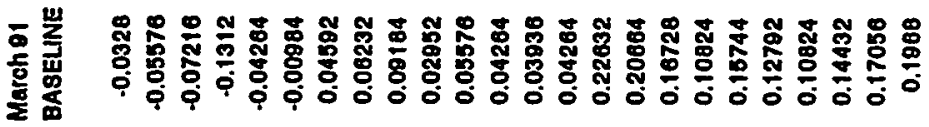

京

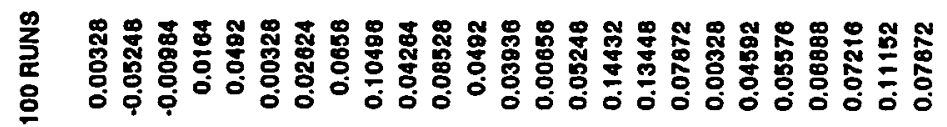

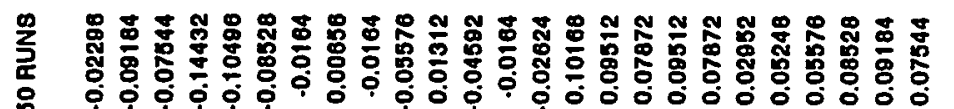

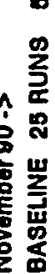

웅

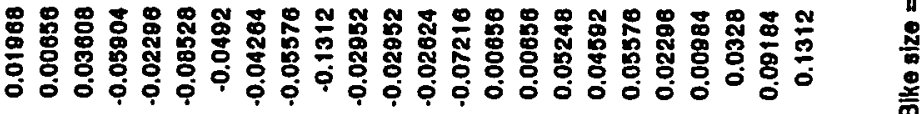

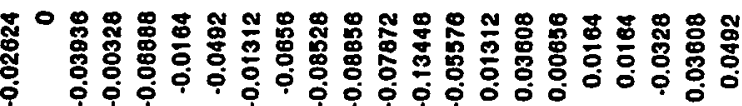

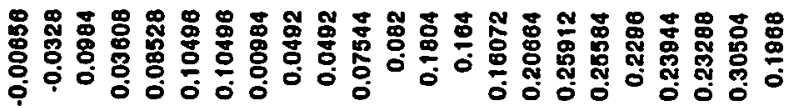

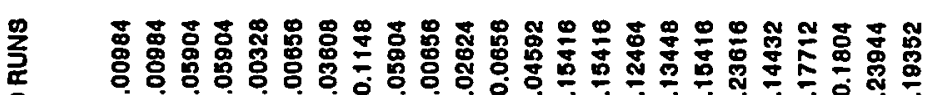

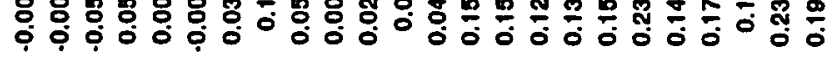

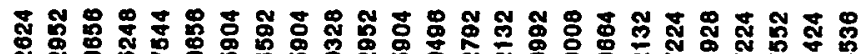

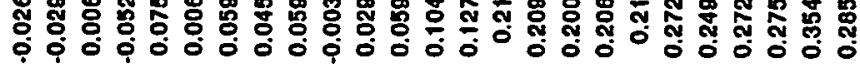

$\hat{\dot{\theta}}$

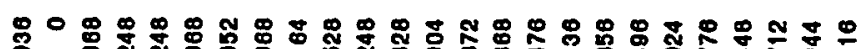

总焉

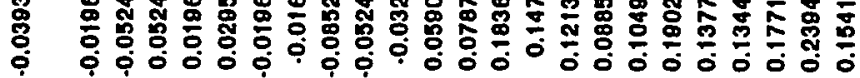

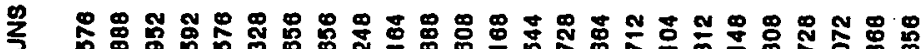

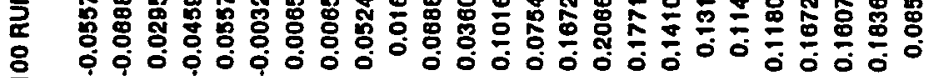

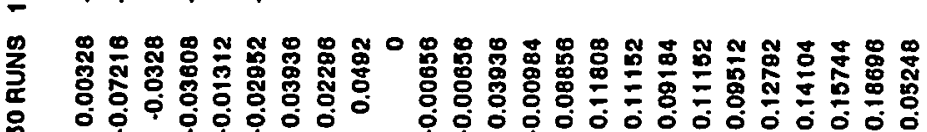

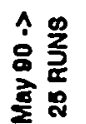

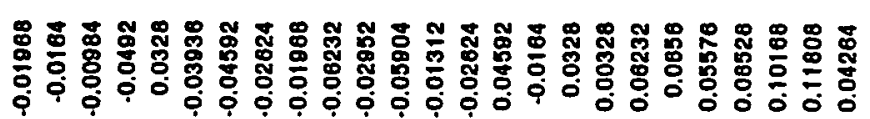

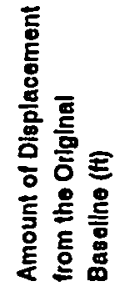

$\underset{x}{\stackrel{m}{3}}$

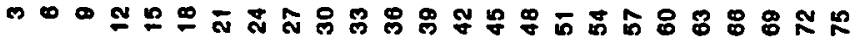




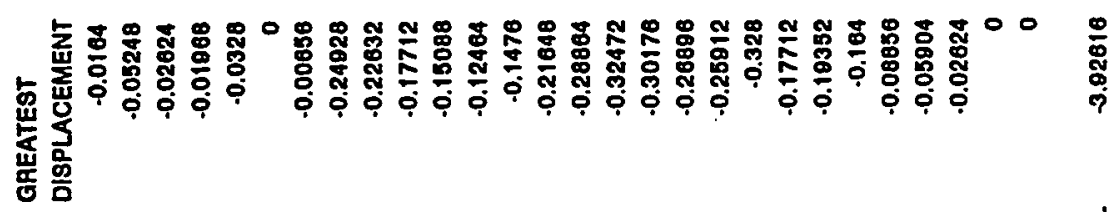

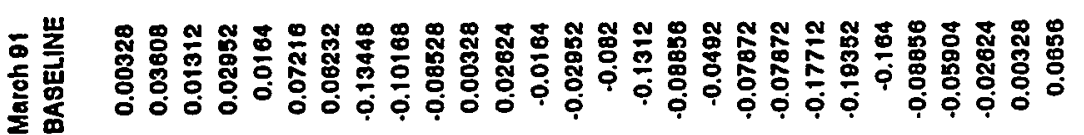

总

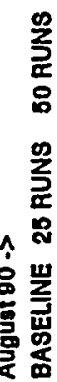

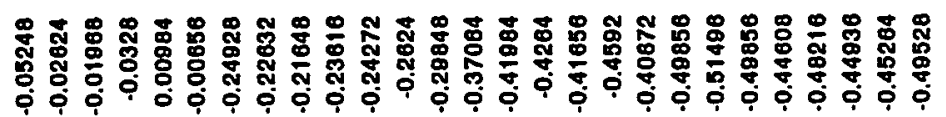

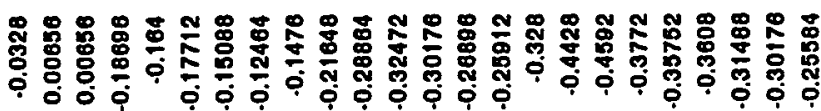

홍

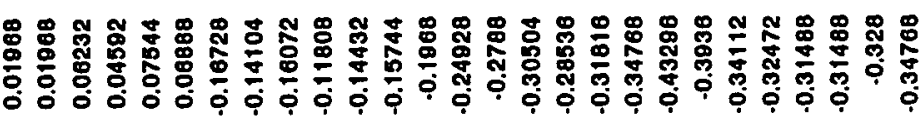

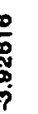

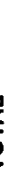

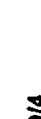

咅

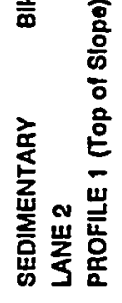

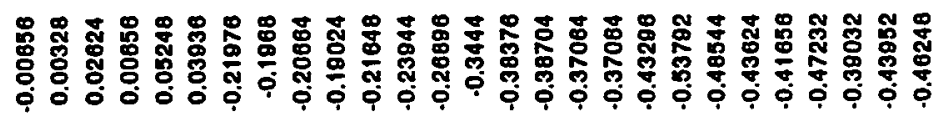

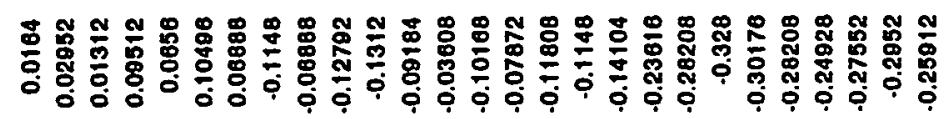

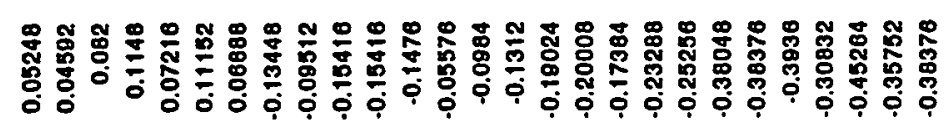

$\hat{\leftrightarrow}$

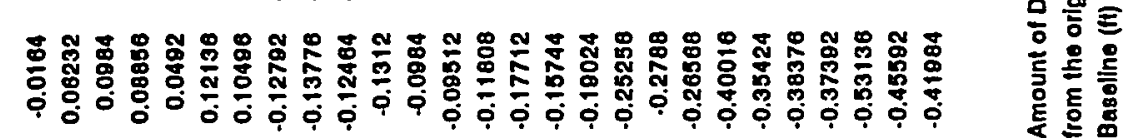

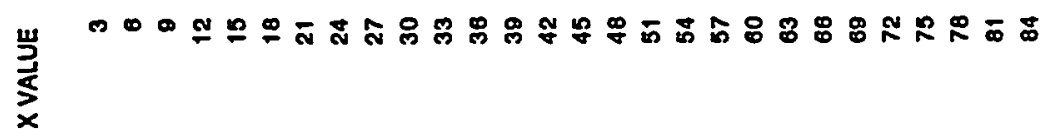



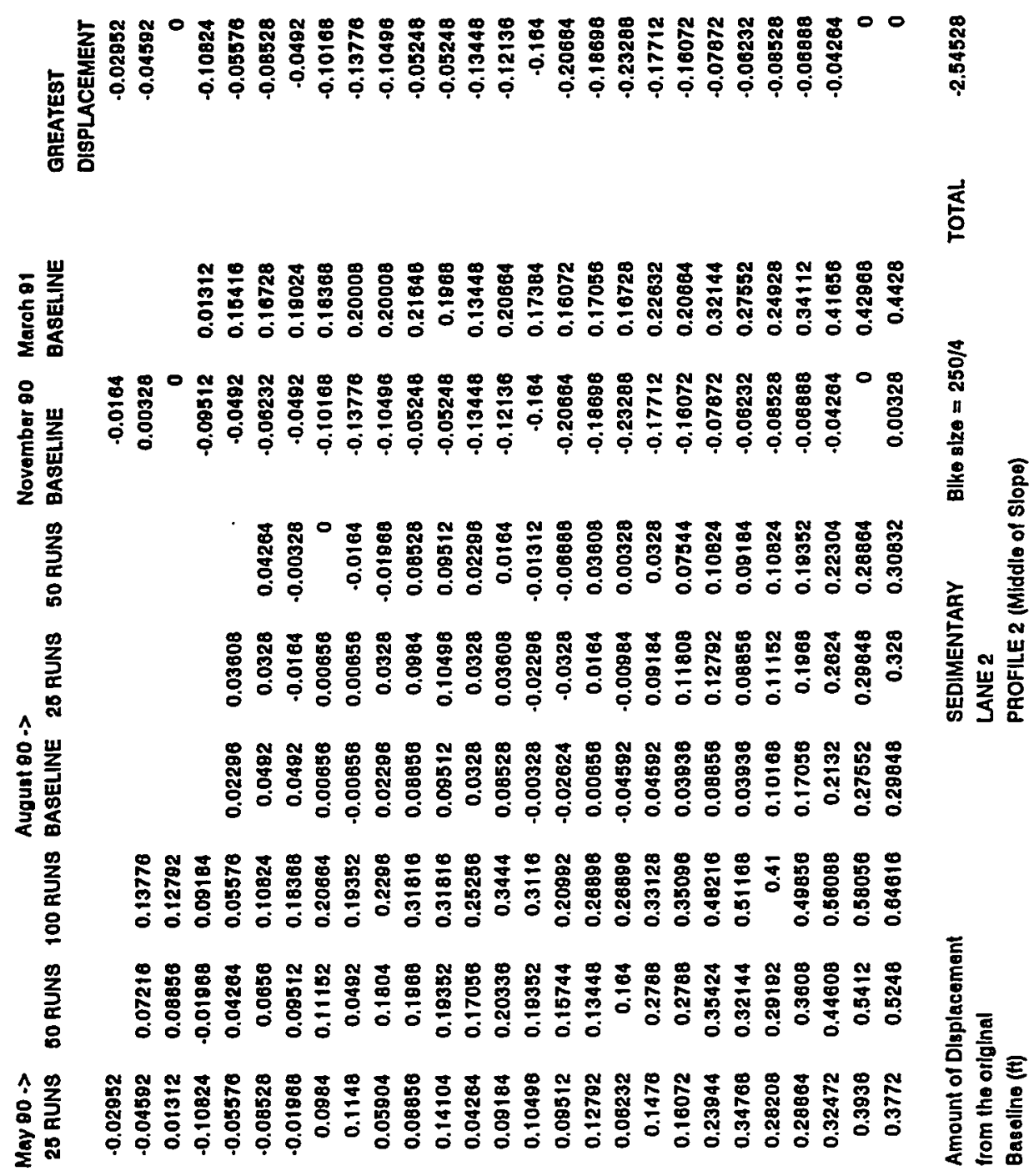

$\underset{x}{\stackrel{u}{3}}$ 

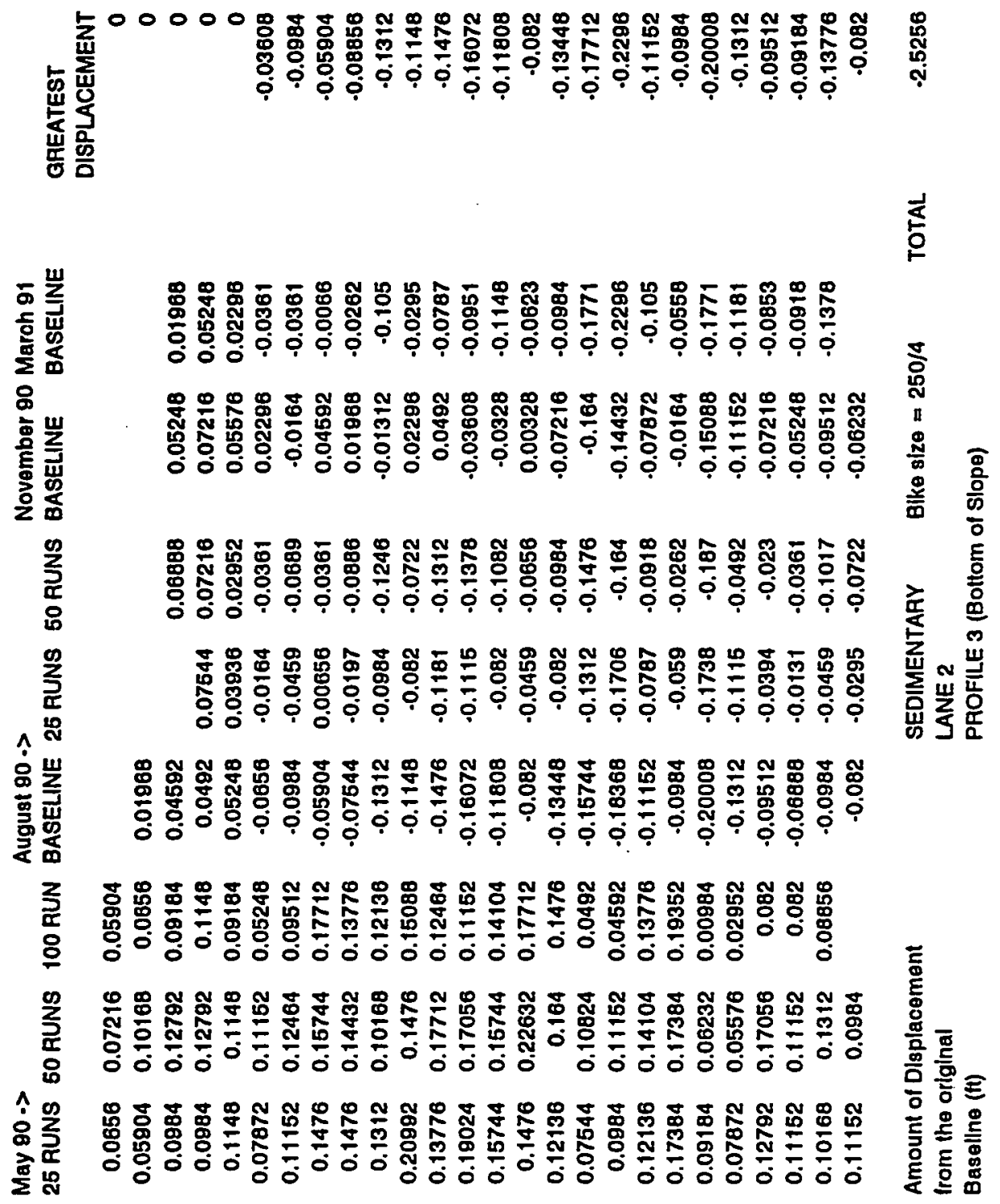

崖 


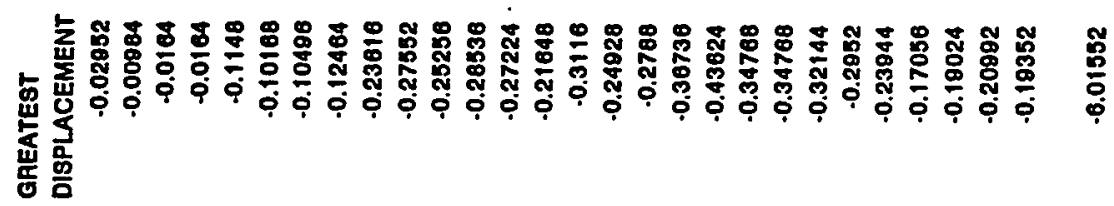

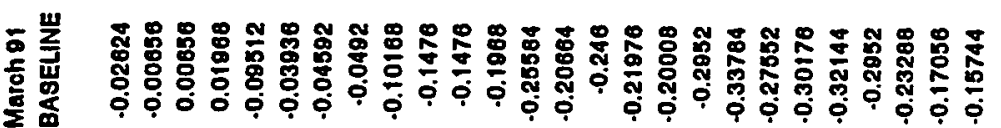

志

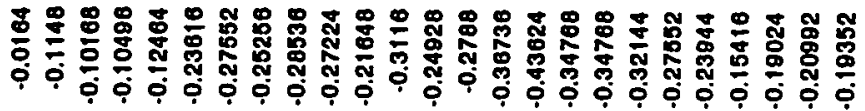

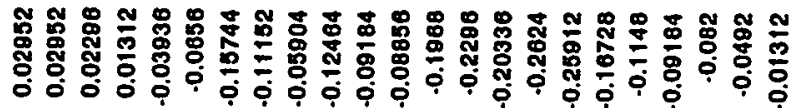

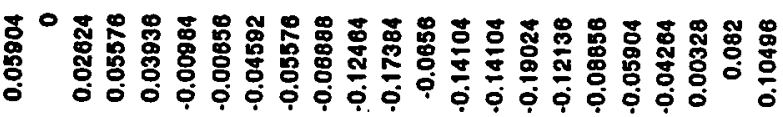

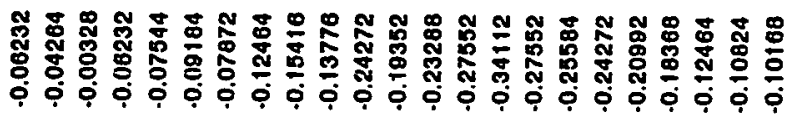

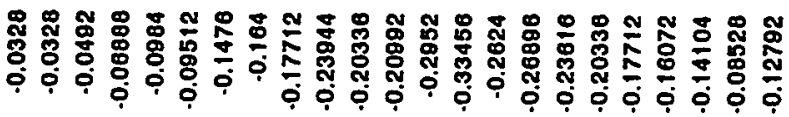

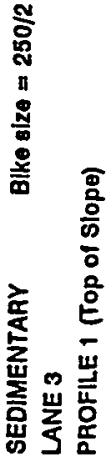

蛋

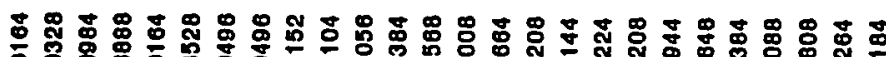

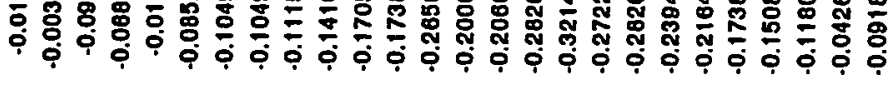

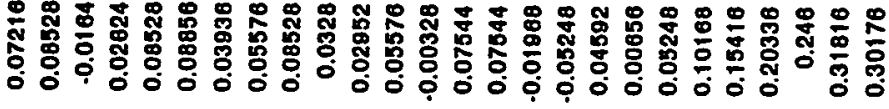

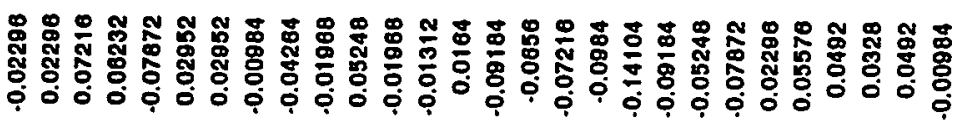

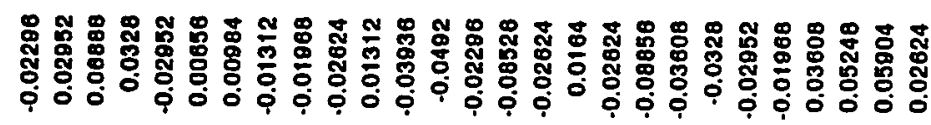

离是

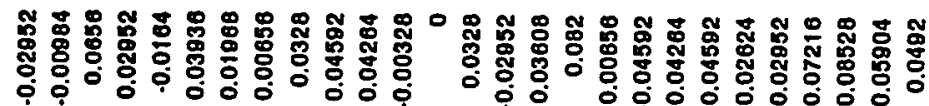

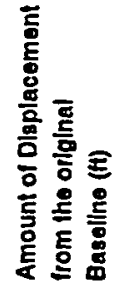

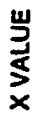

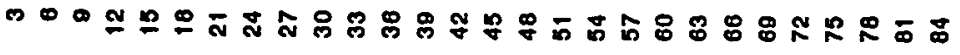




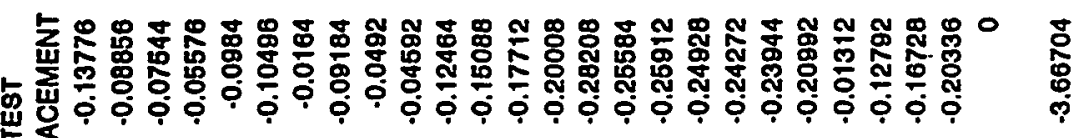

崖喜

혼

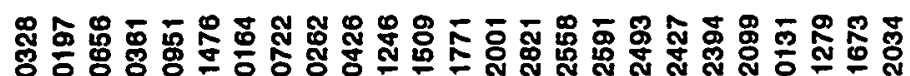

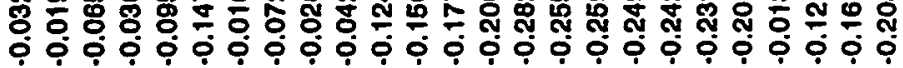

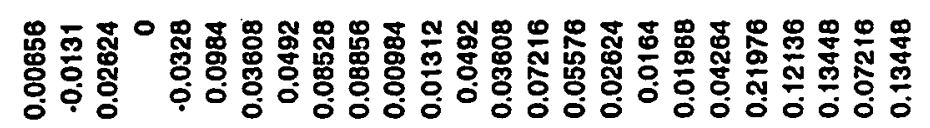

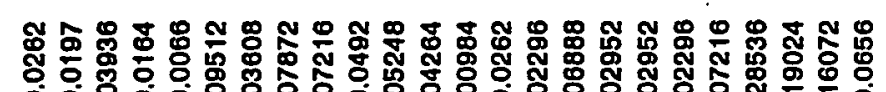

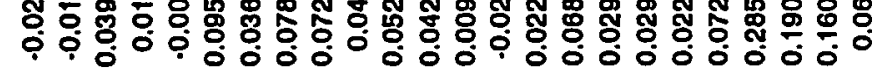

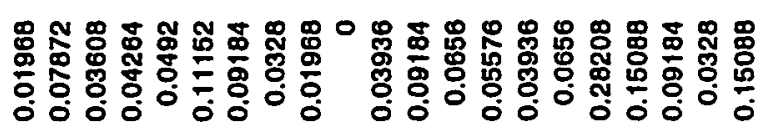

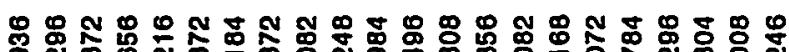

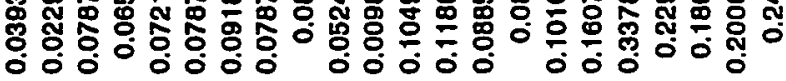

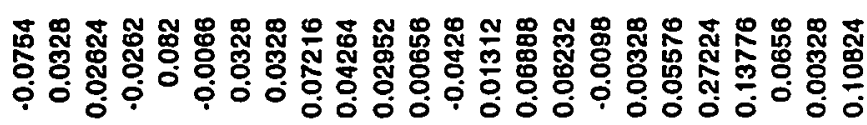

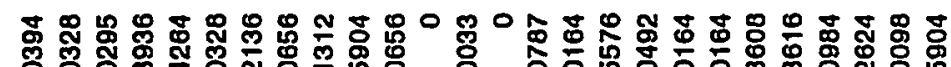

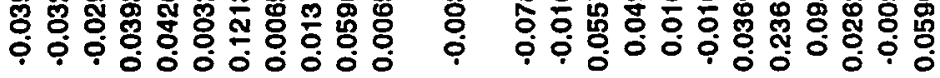

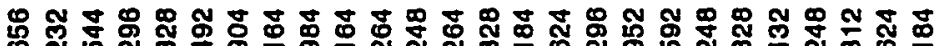

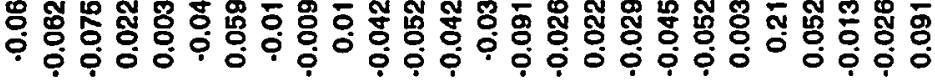

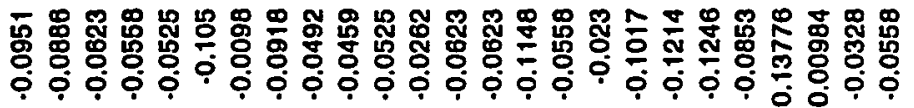

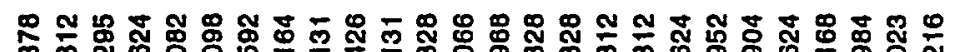

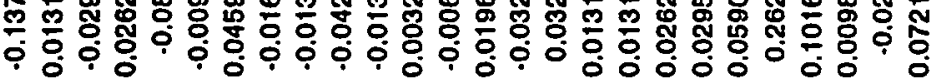

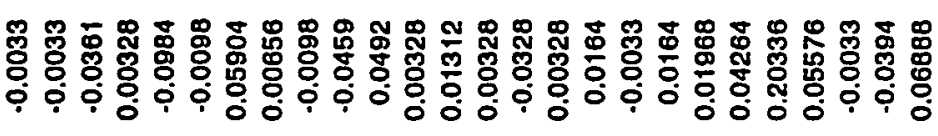

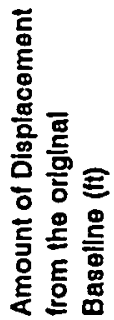




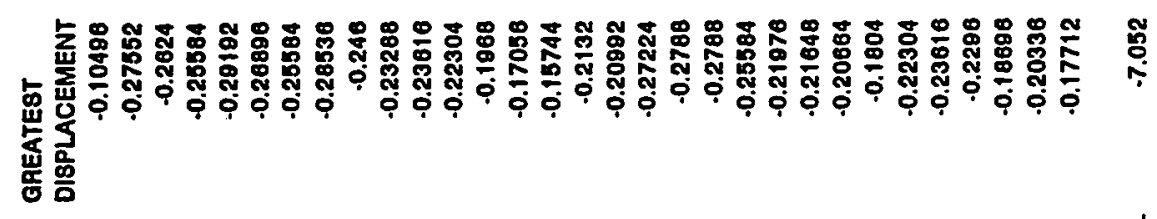

志

万岸

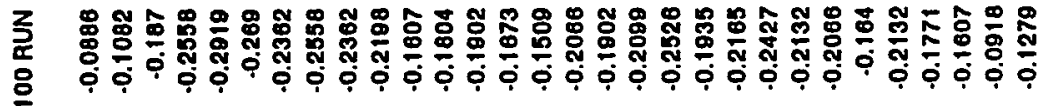

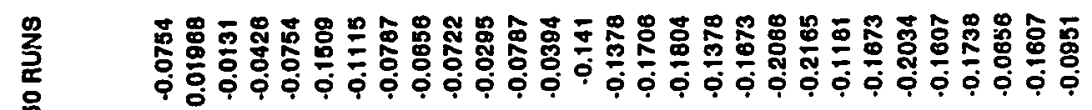

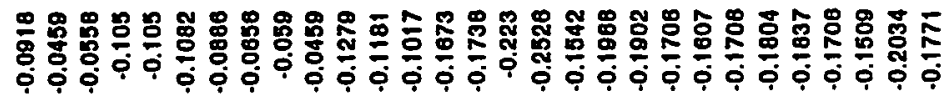

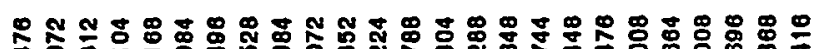

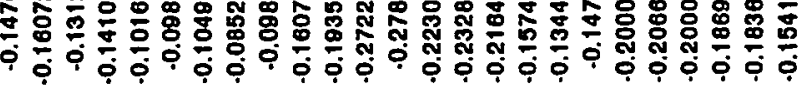

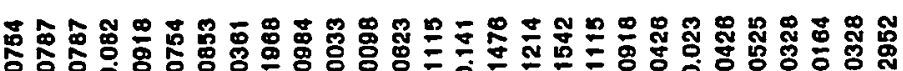

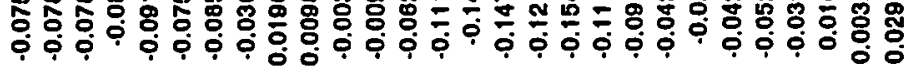

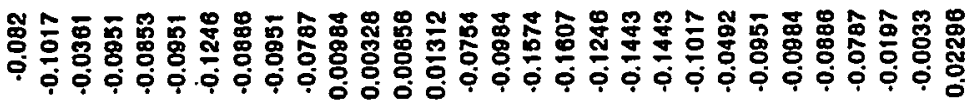

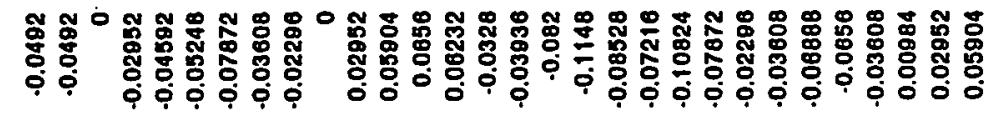

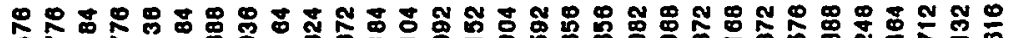

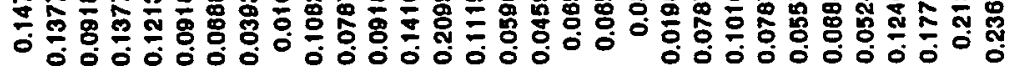

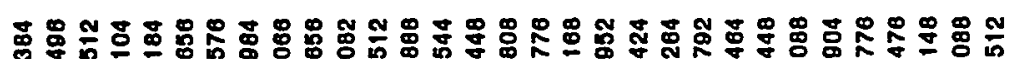

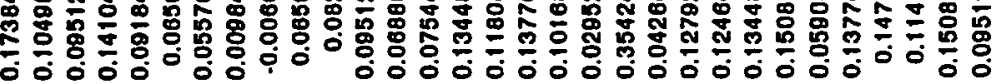

安总

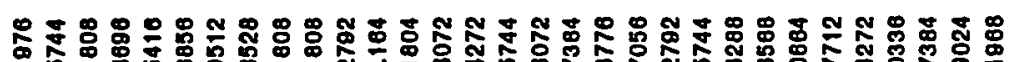

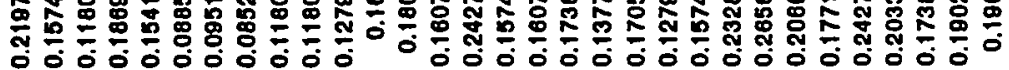

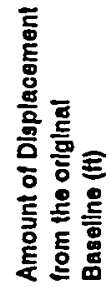


홀

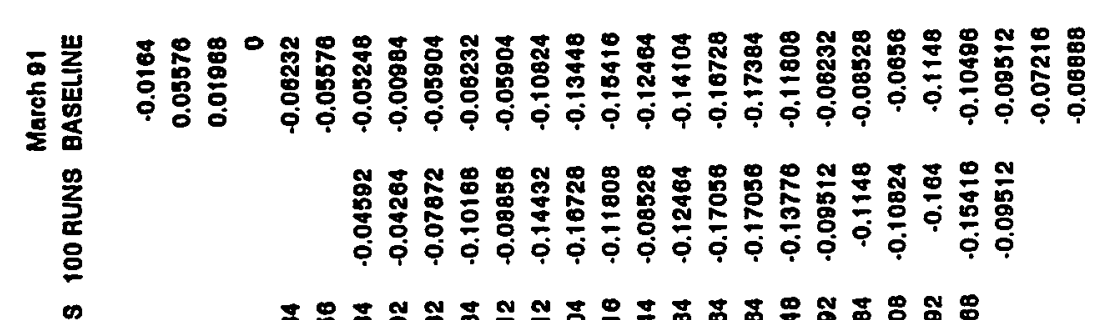

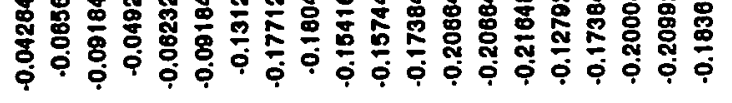

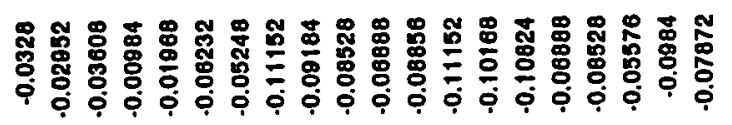

品

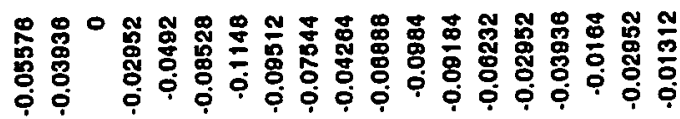

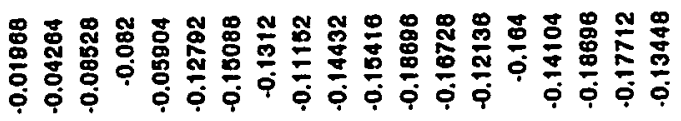

$\stackrel{\overrightarrow{5}}{\underline{\underline{5}}}$

要崖

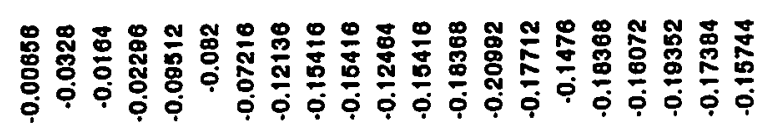

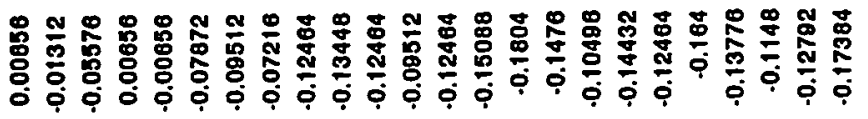

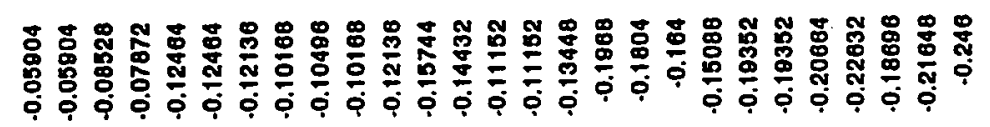

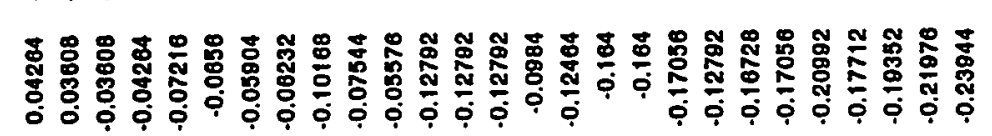

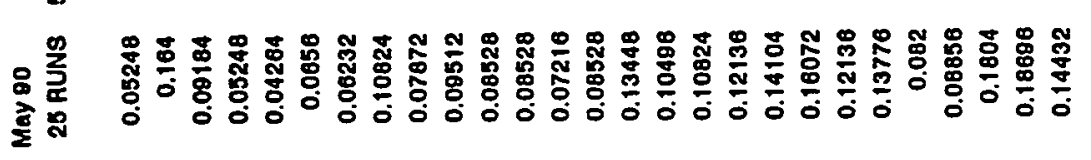

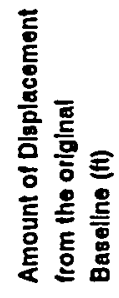

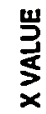

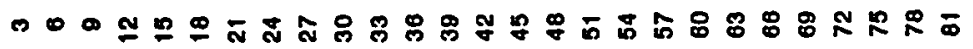


兽 빙

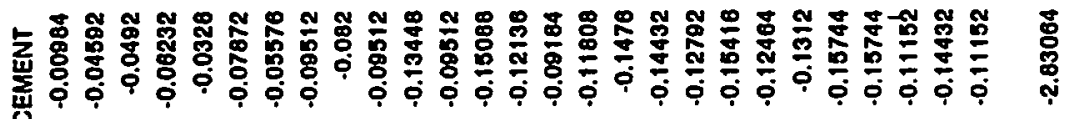

悹离

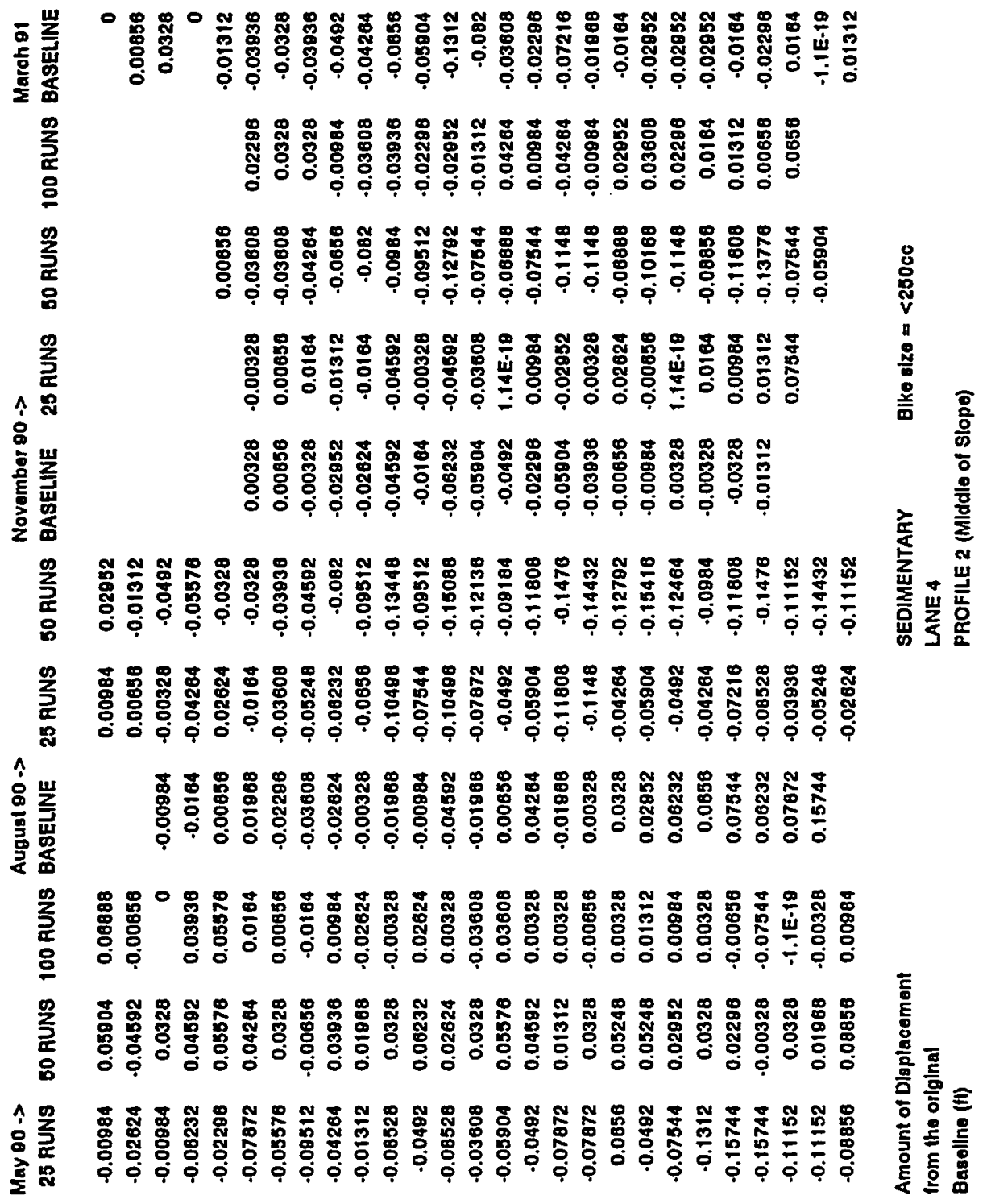




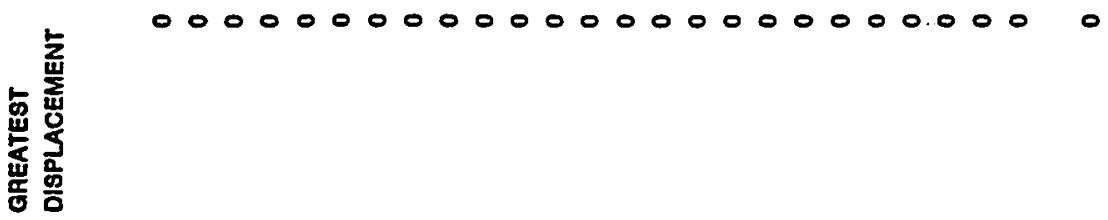

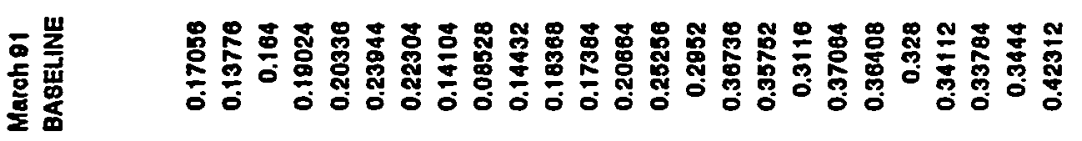

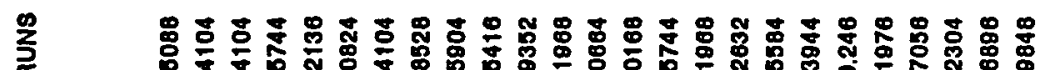

눙

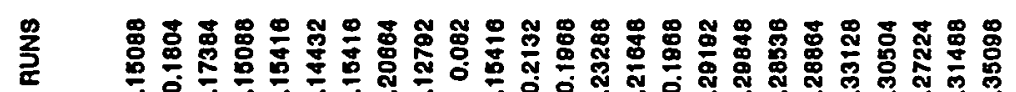

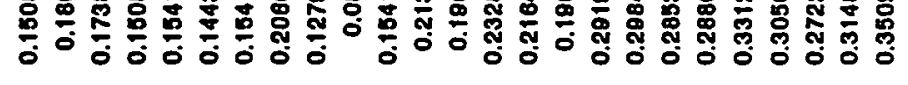

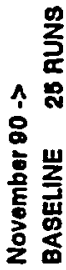

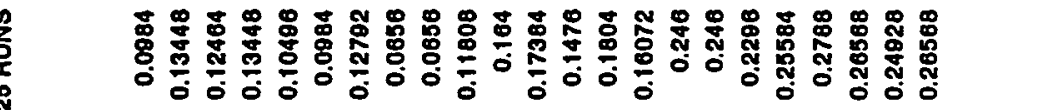

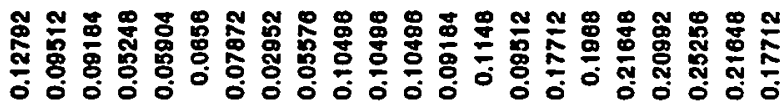

吝

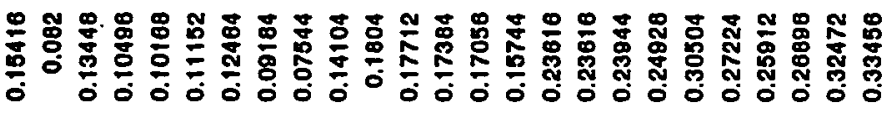

喜

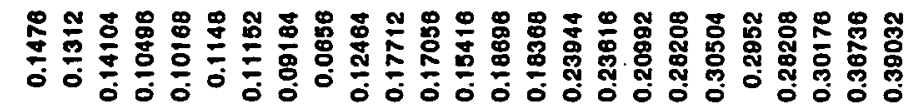

它宸

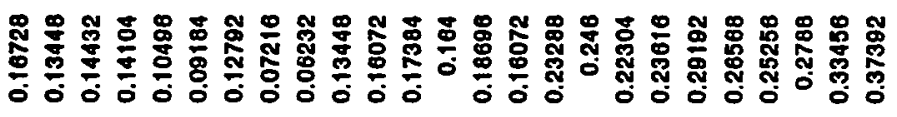

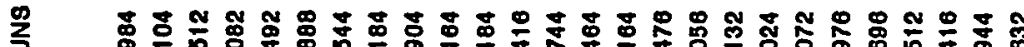

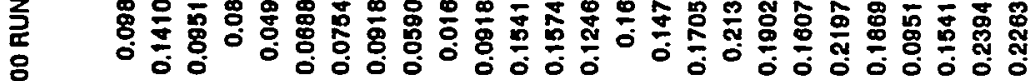

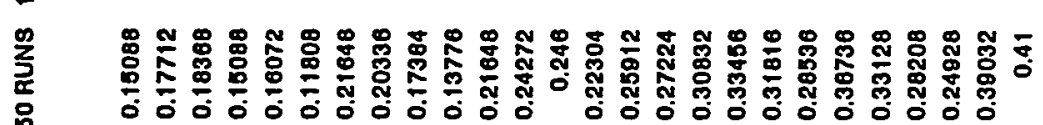

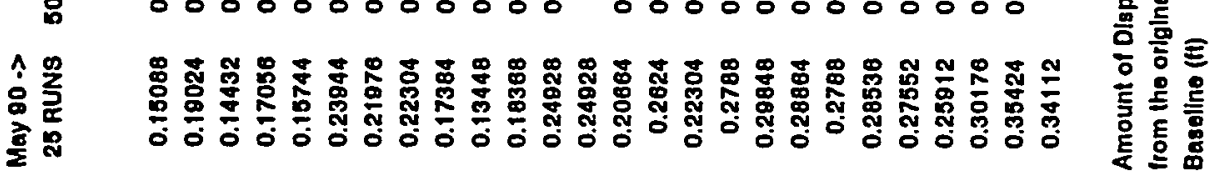

$\stackrel{\text { 岁 }}{\stackrel{3}{\mathbf{z}}}$

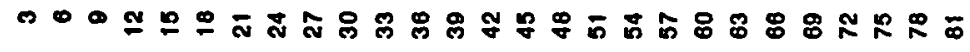




\section{APPEIDIX B - SOIL DISPLACEMEAT PROFIIES}

EXPLANATION

The data points labeled "Greatest Displacement" on the enclosed graphs are listed in the column labeled "Greatest Displacement" on the respective tables in Appendix A. Data points representing the greatest displacement of soil at each measuring point along each microprofile were plotted. This graphical representation of each microprofile shows the trail produced by the motorcycles during this study at a given location (profile) along the slope. 


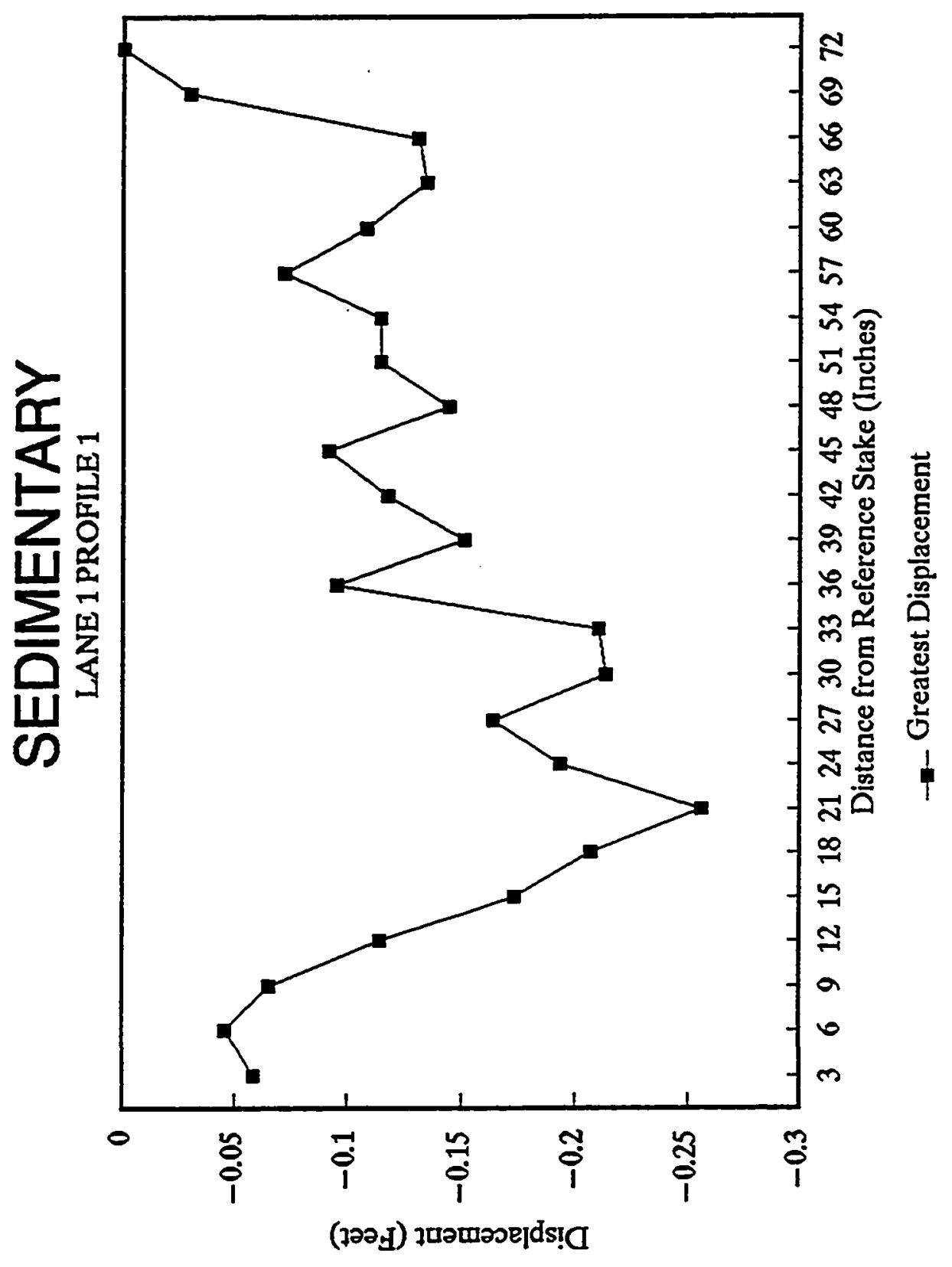




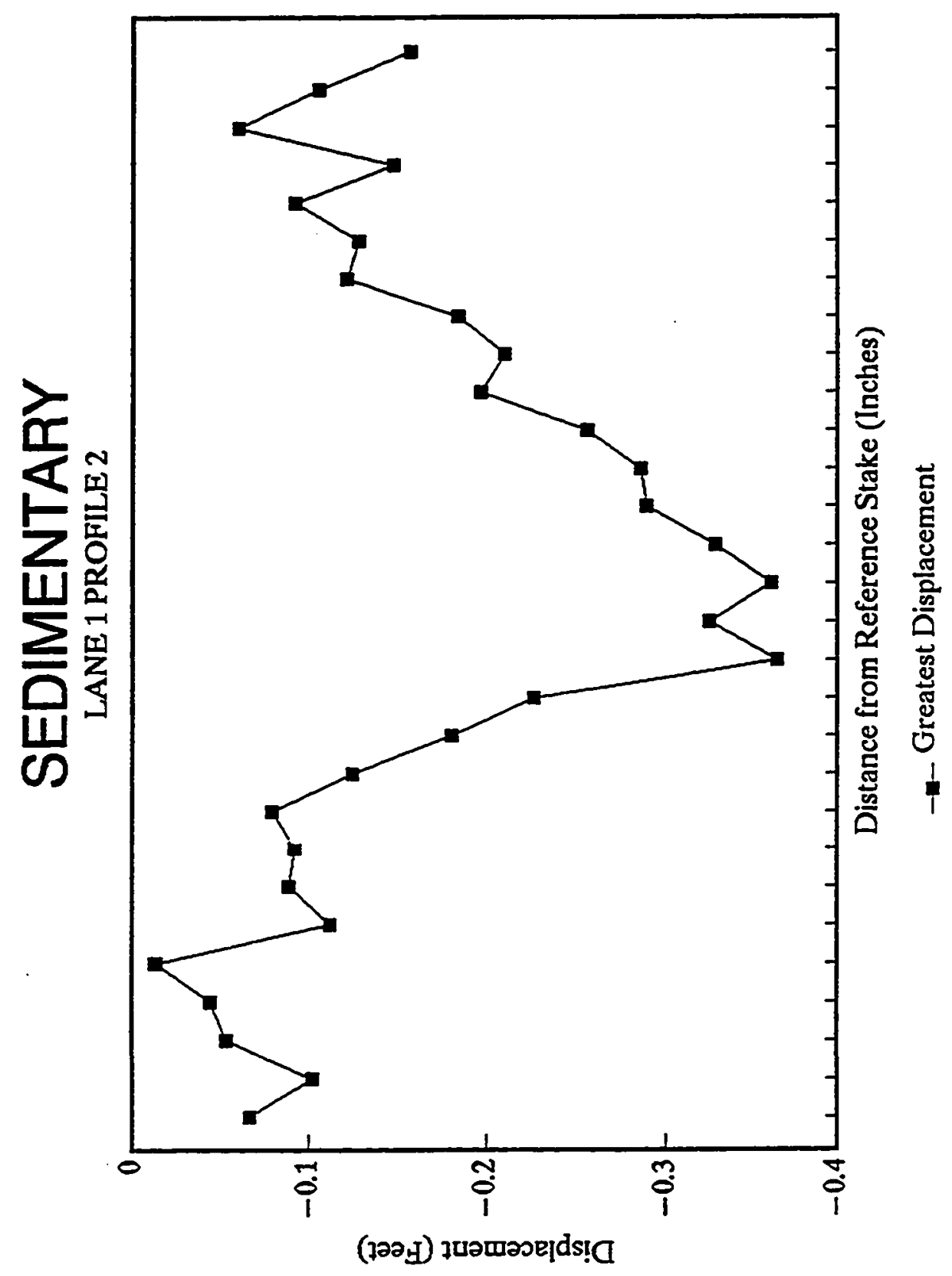




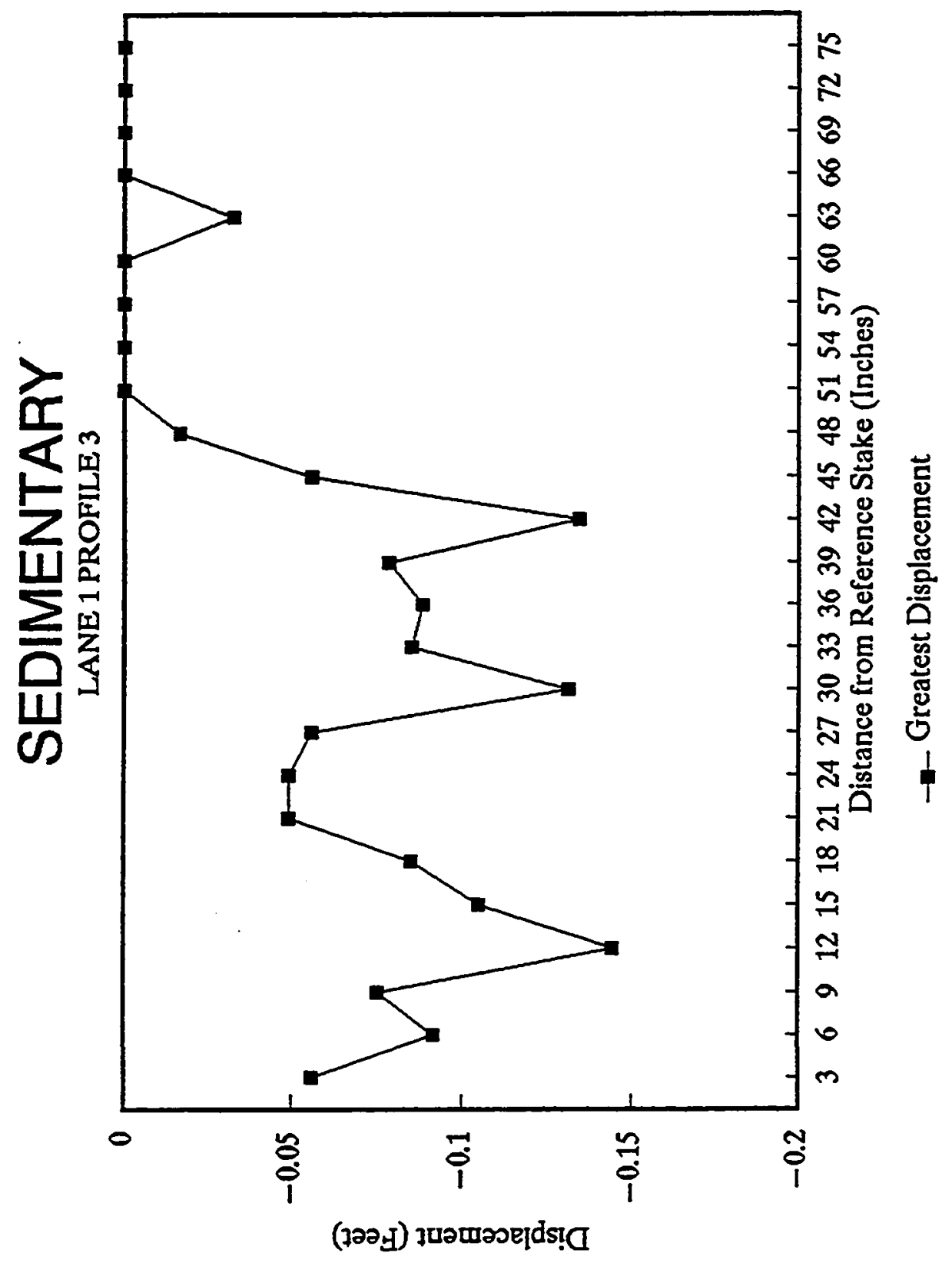




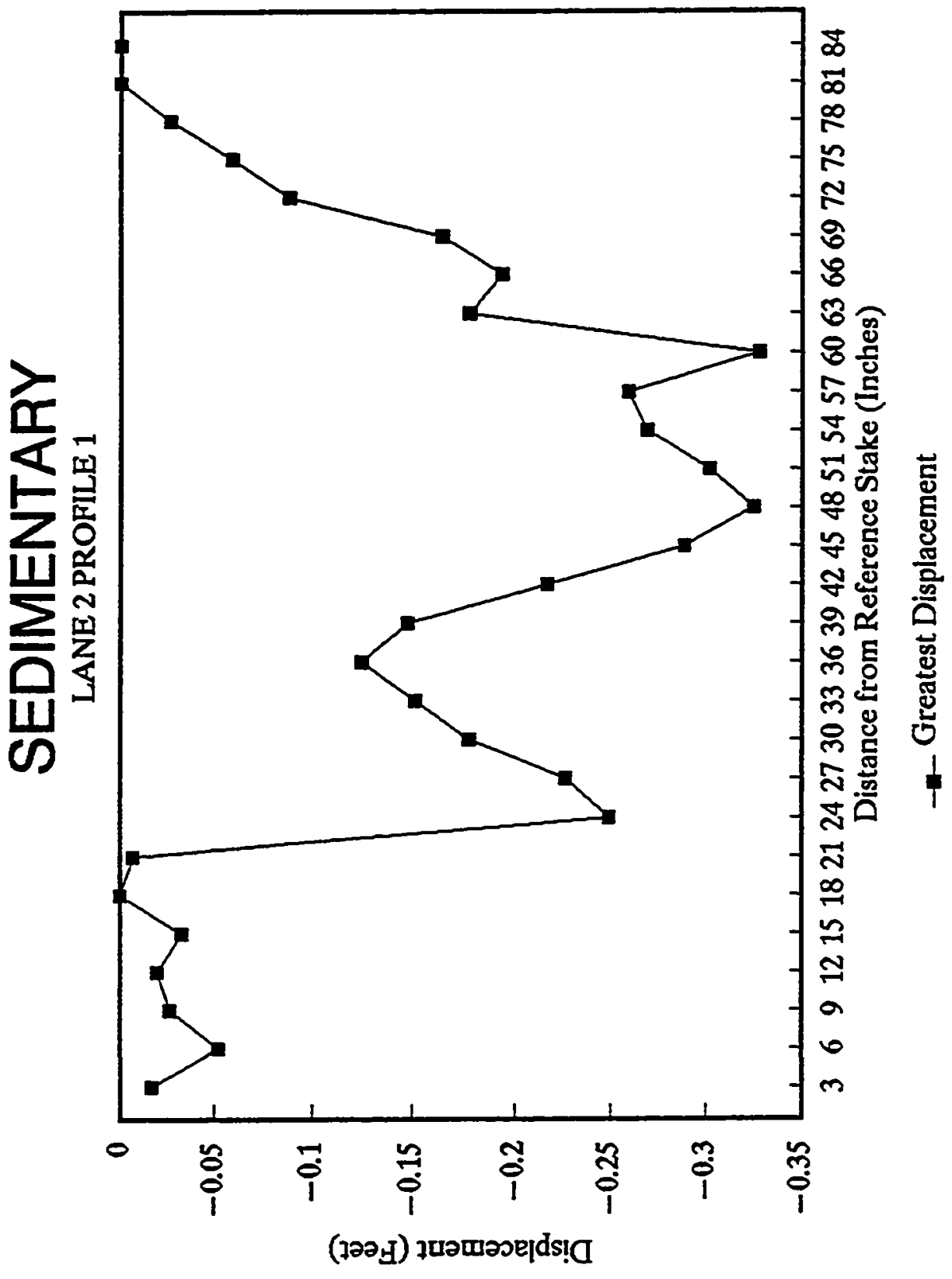




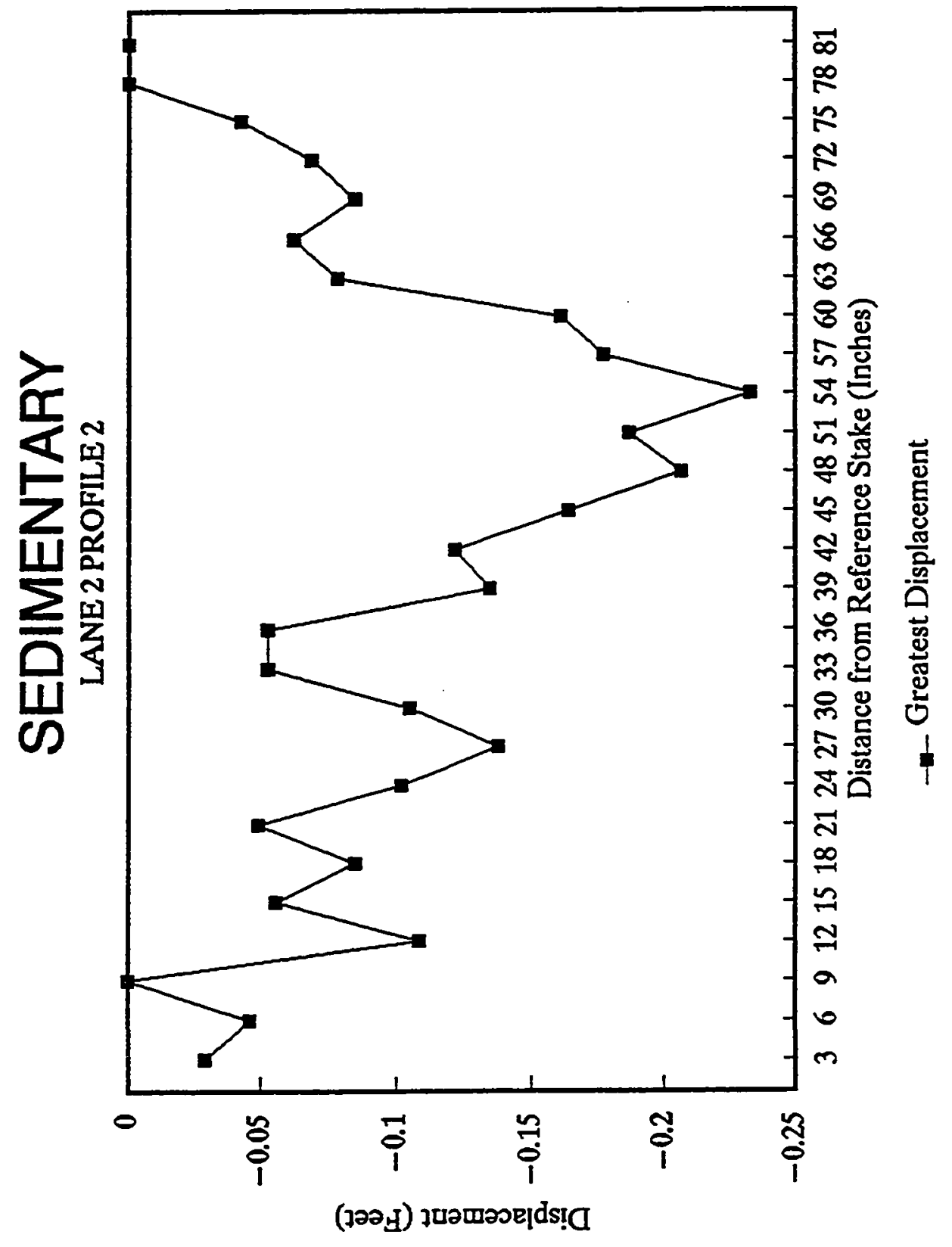




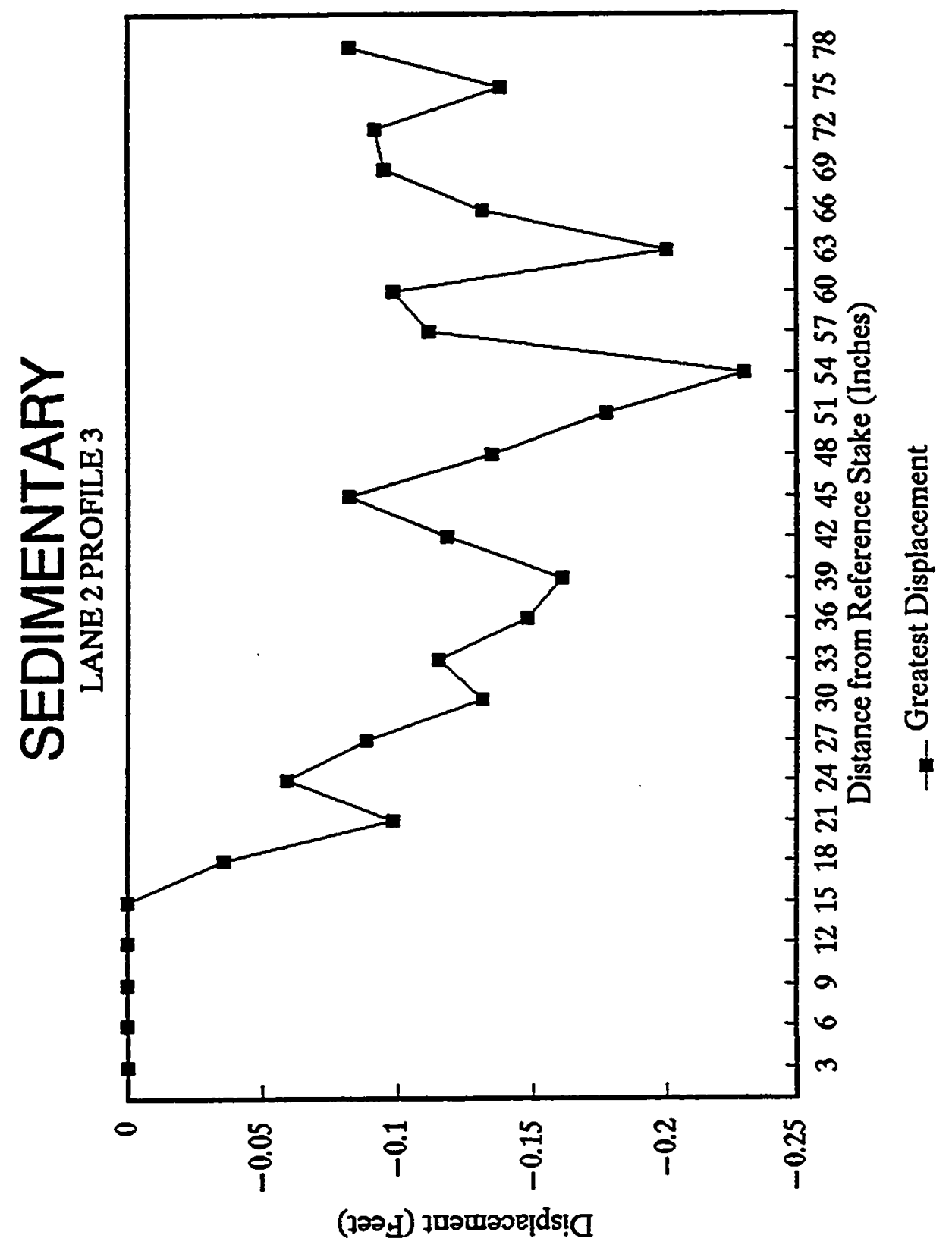




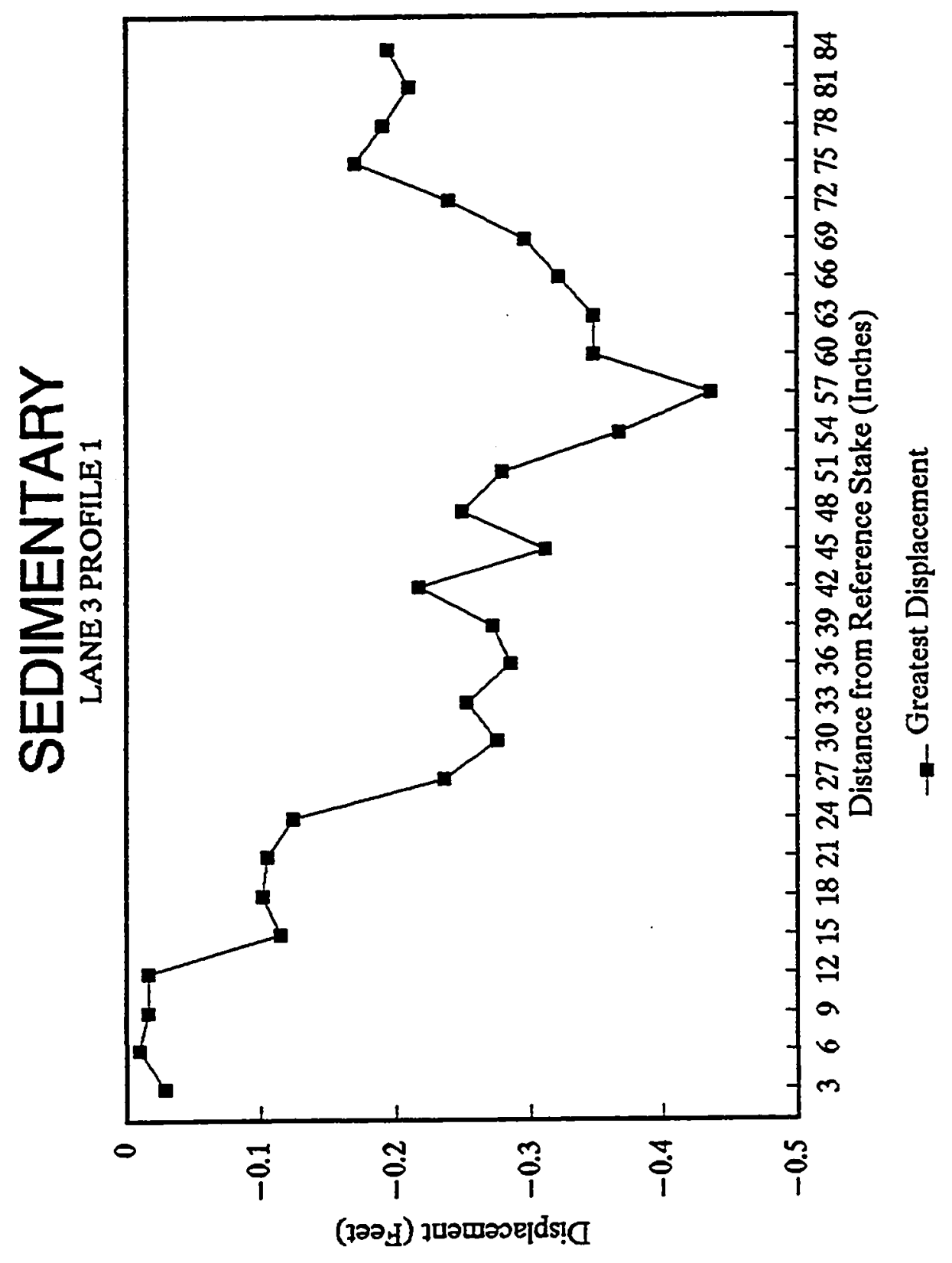




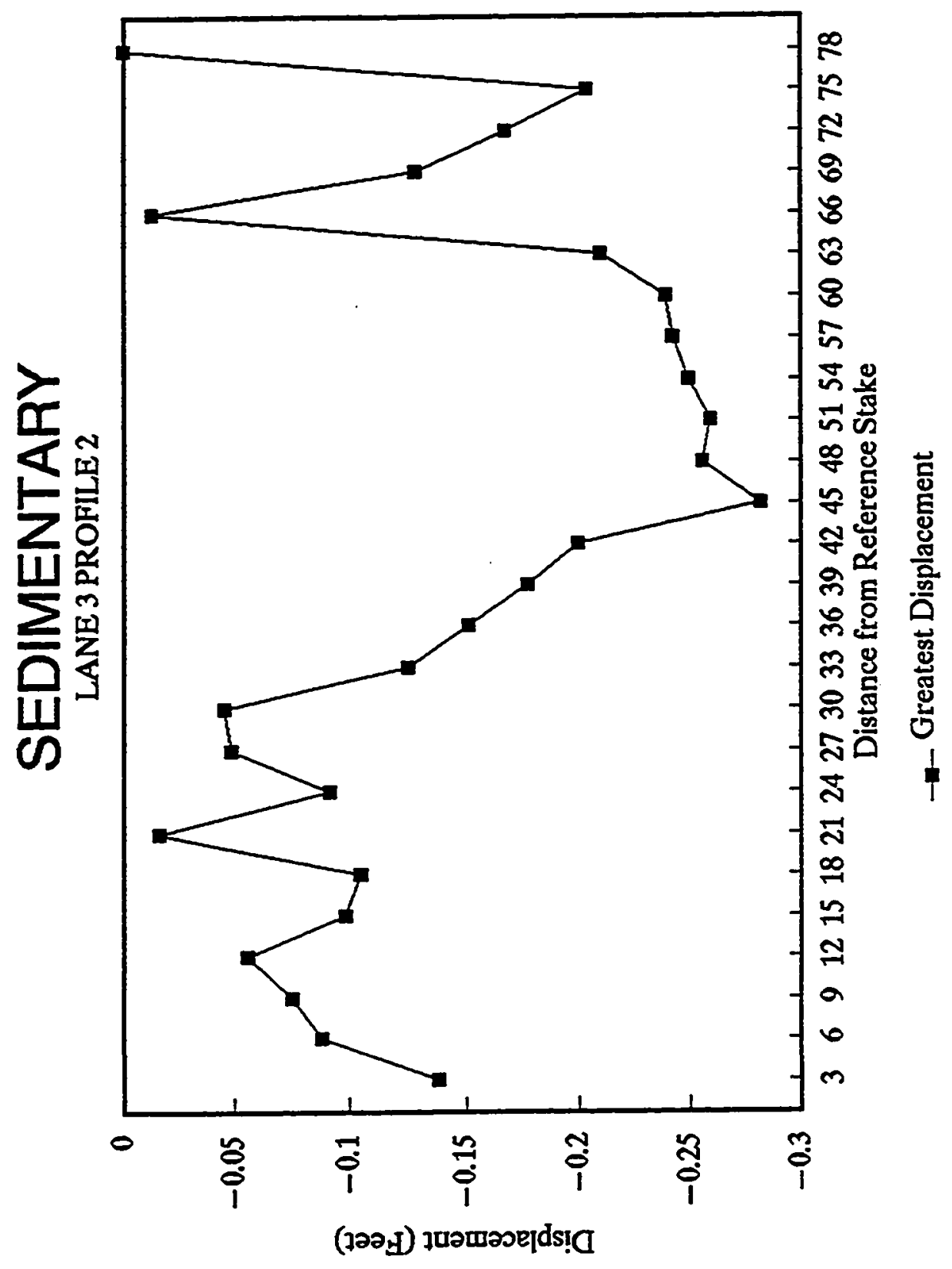




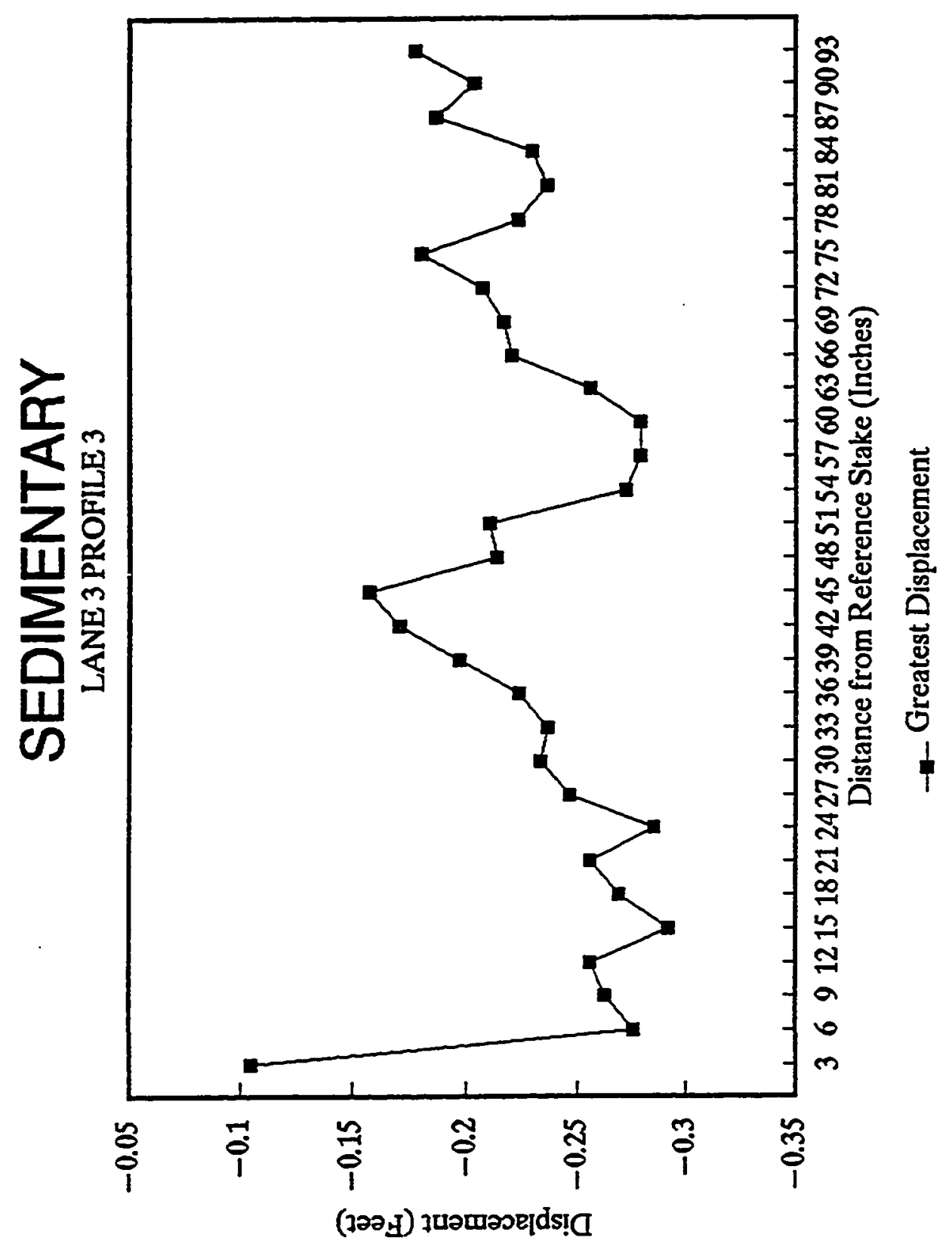




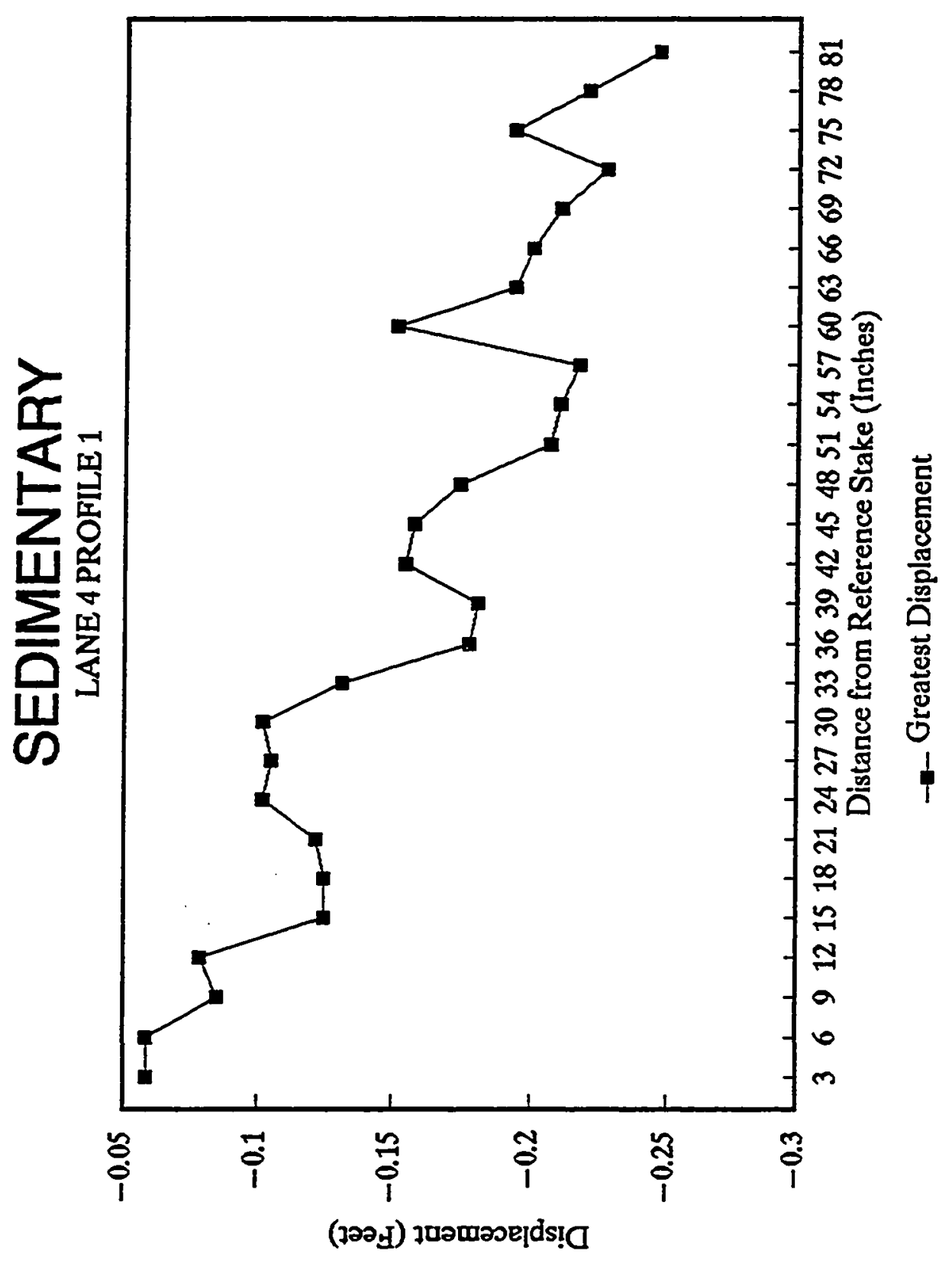




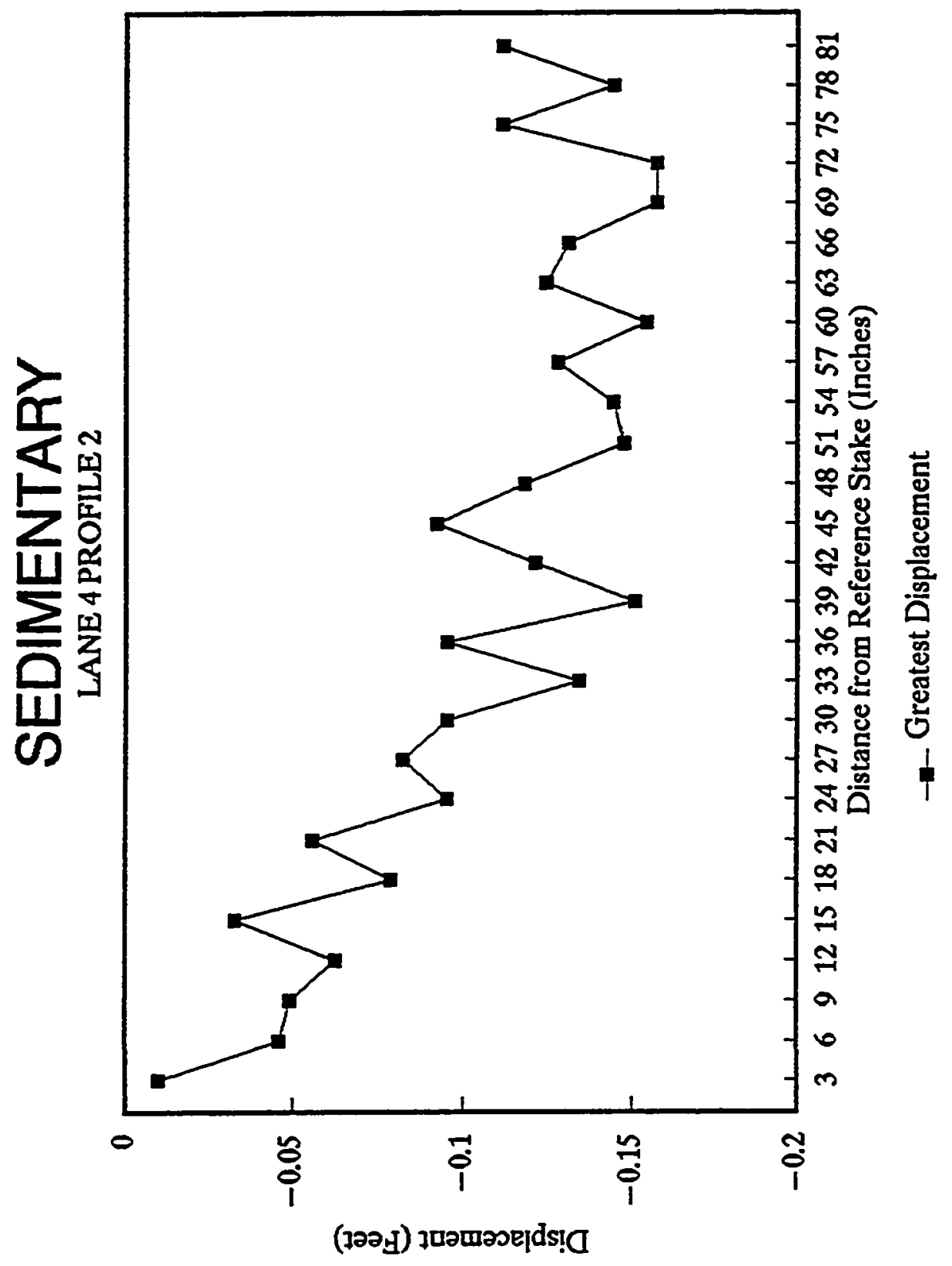




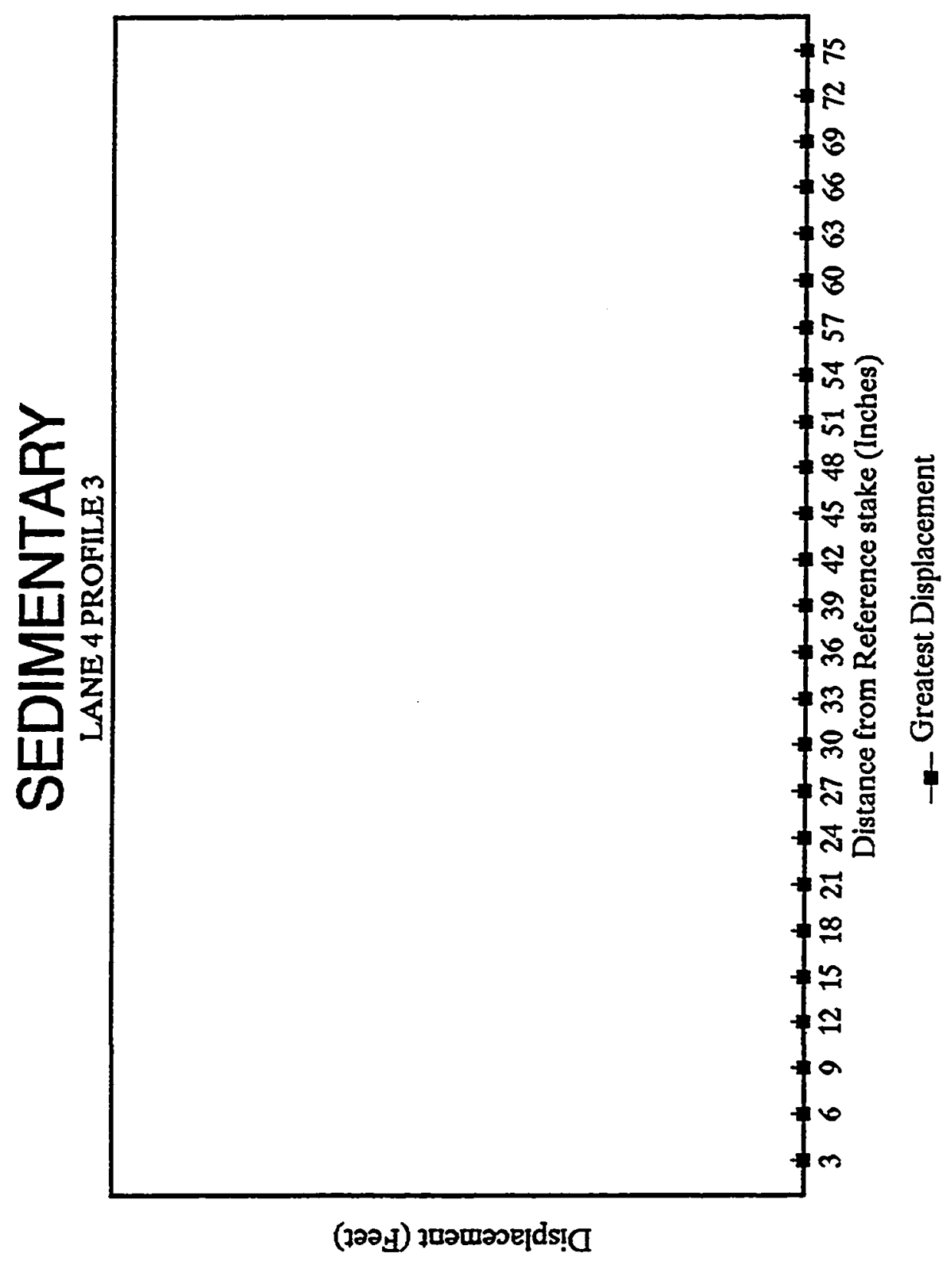




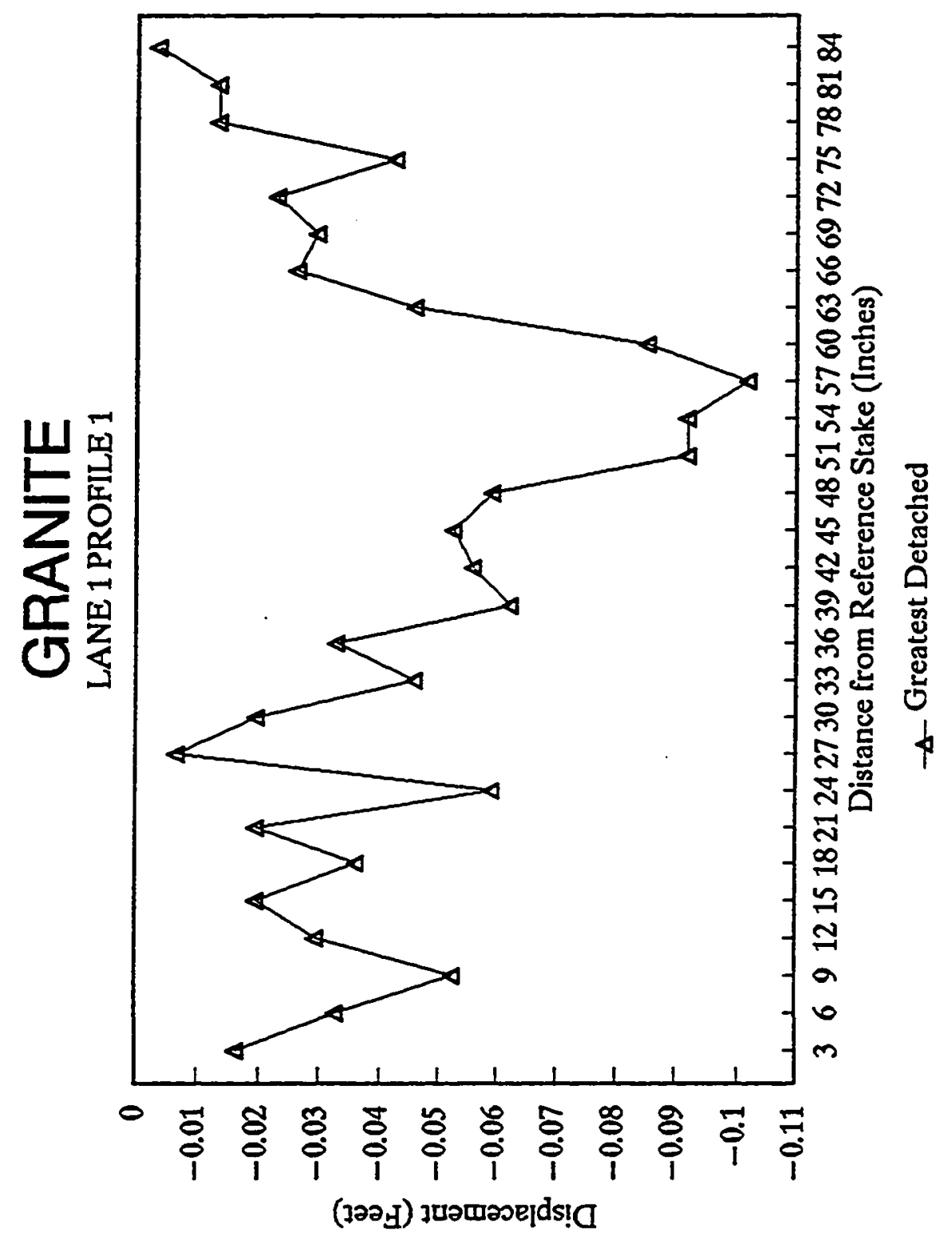




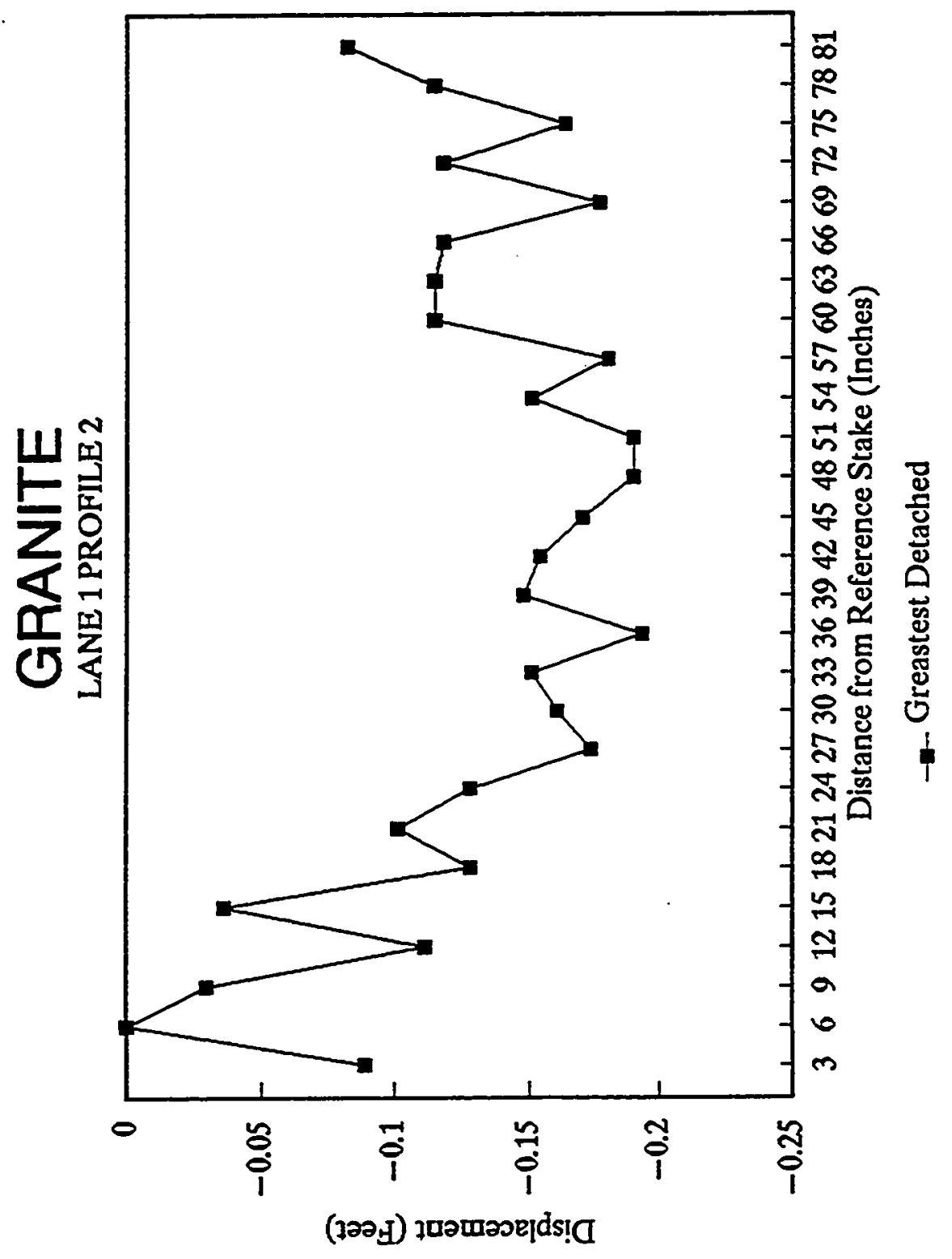




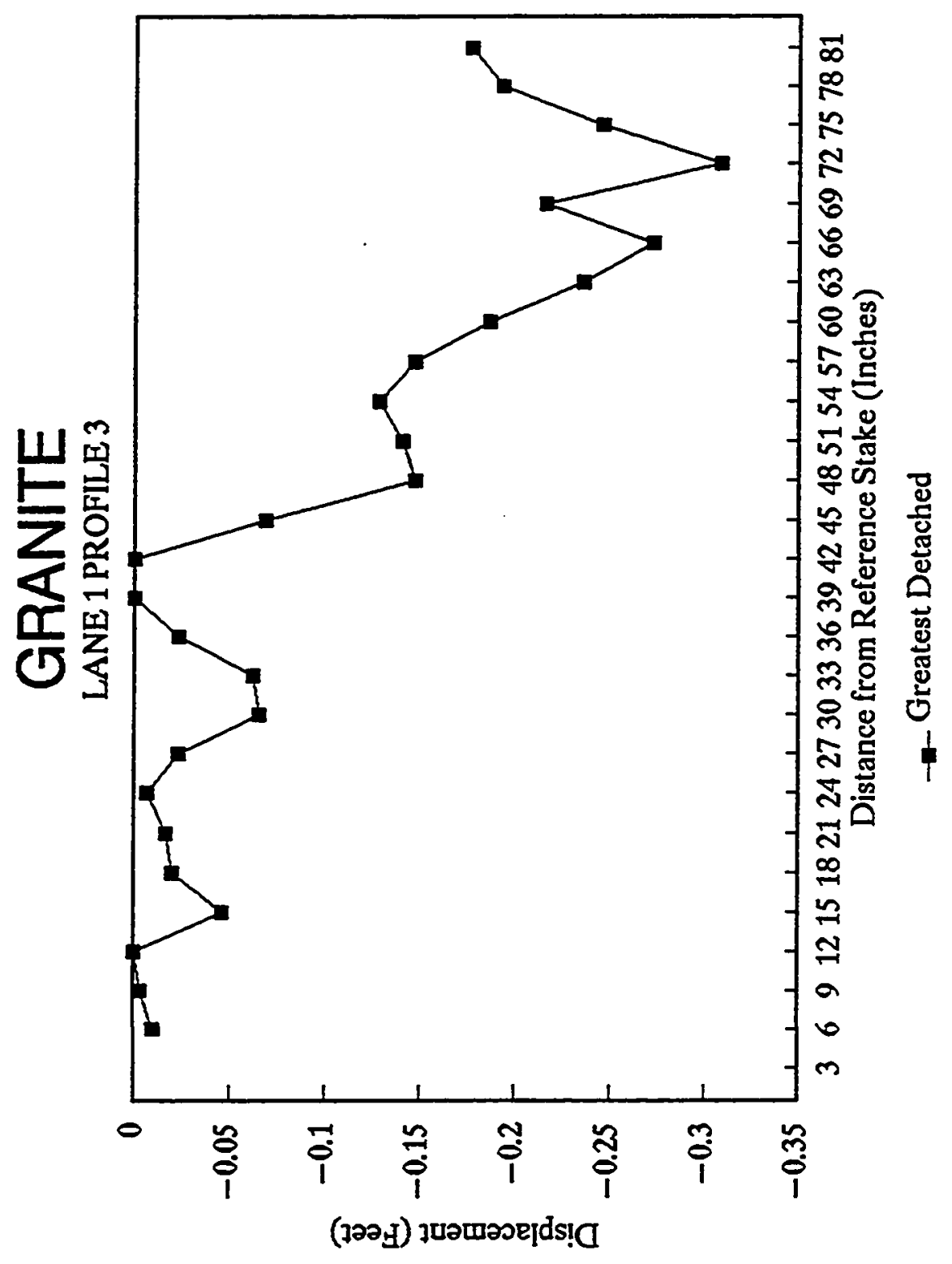




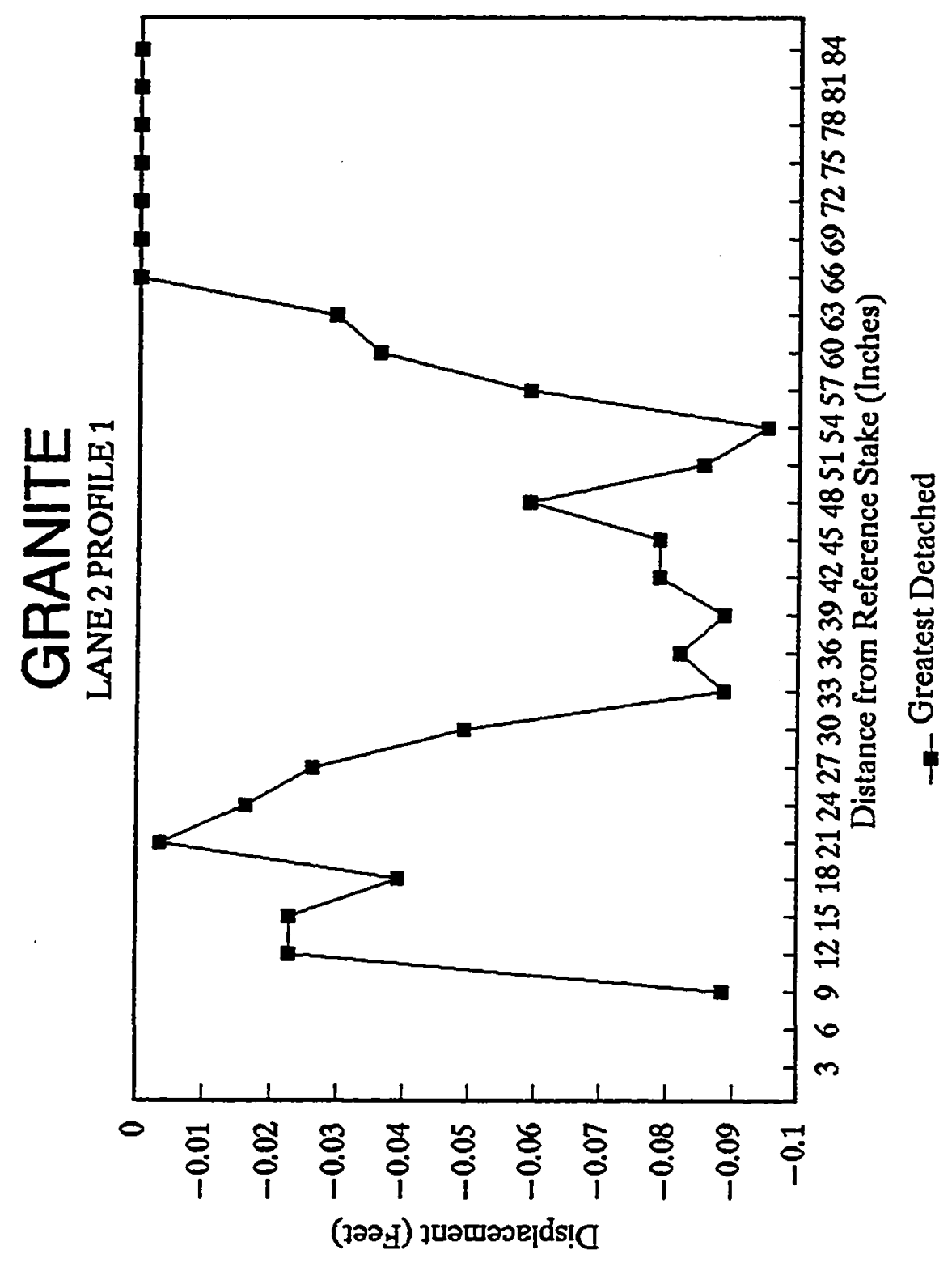




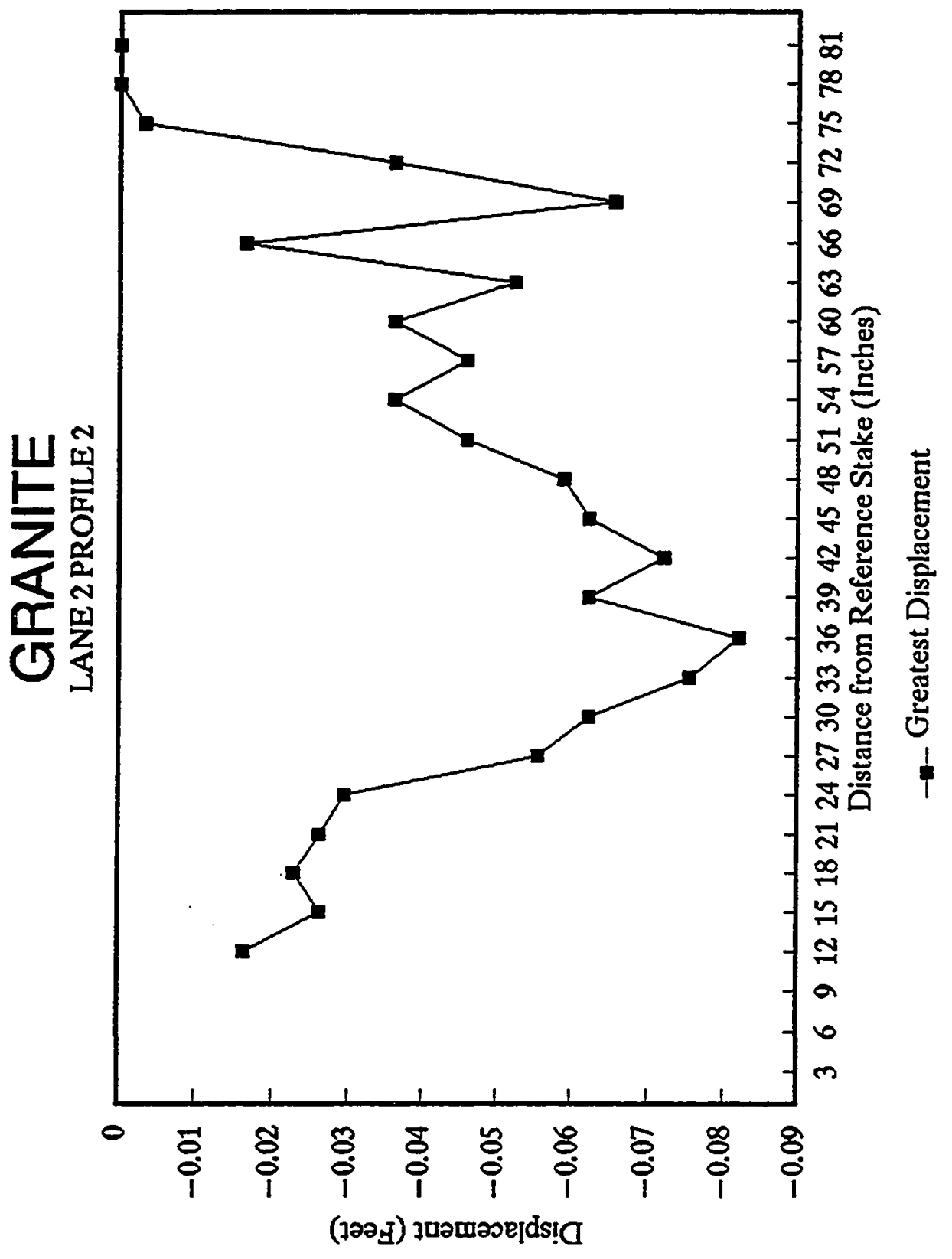




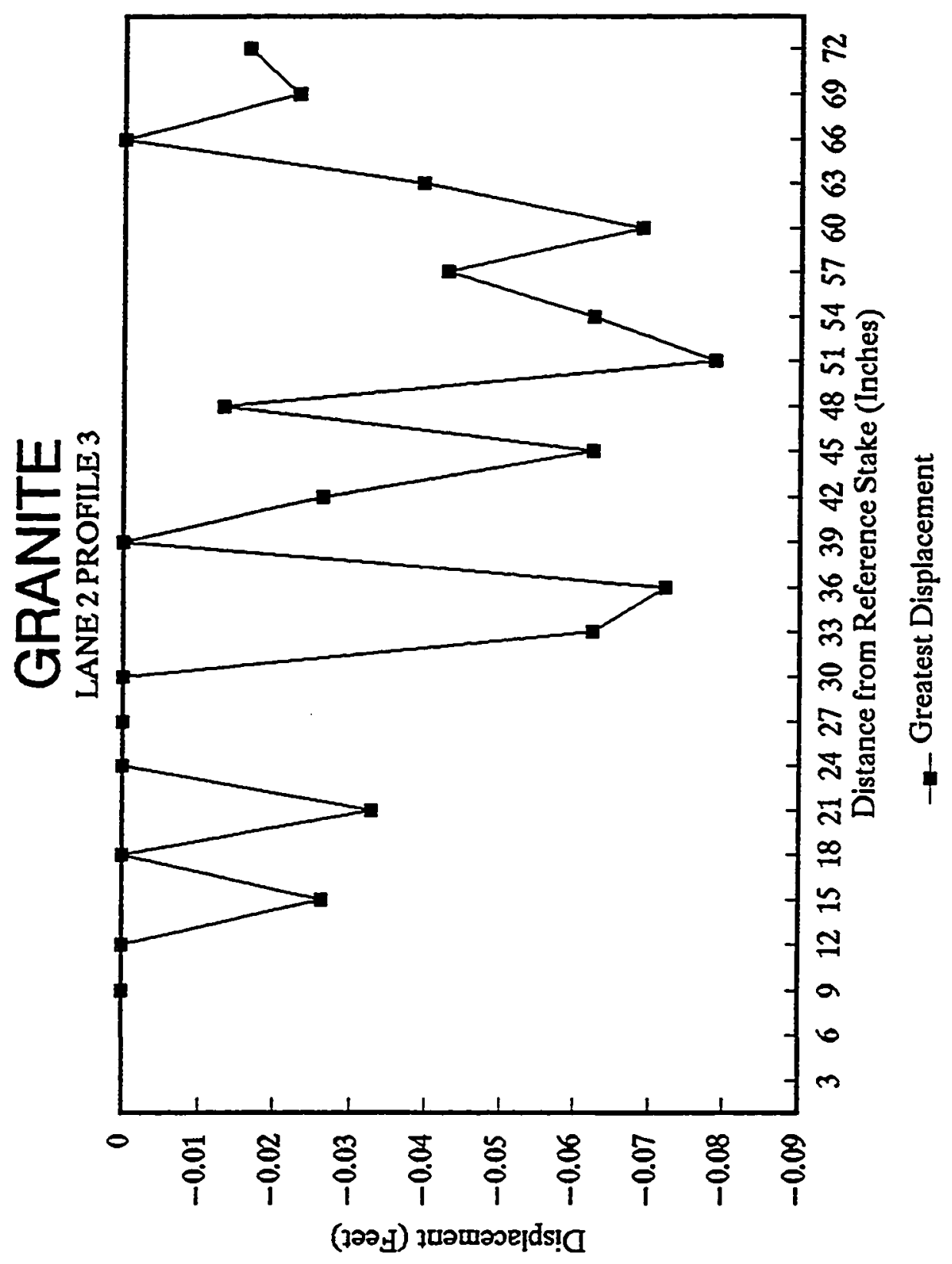




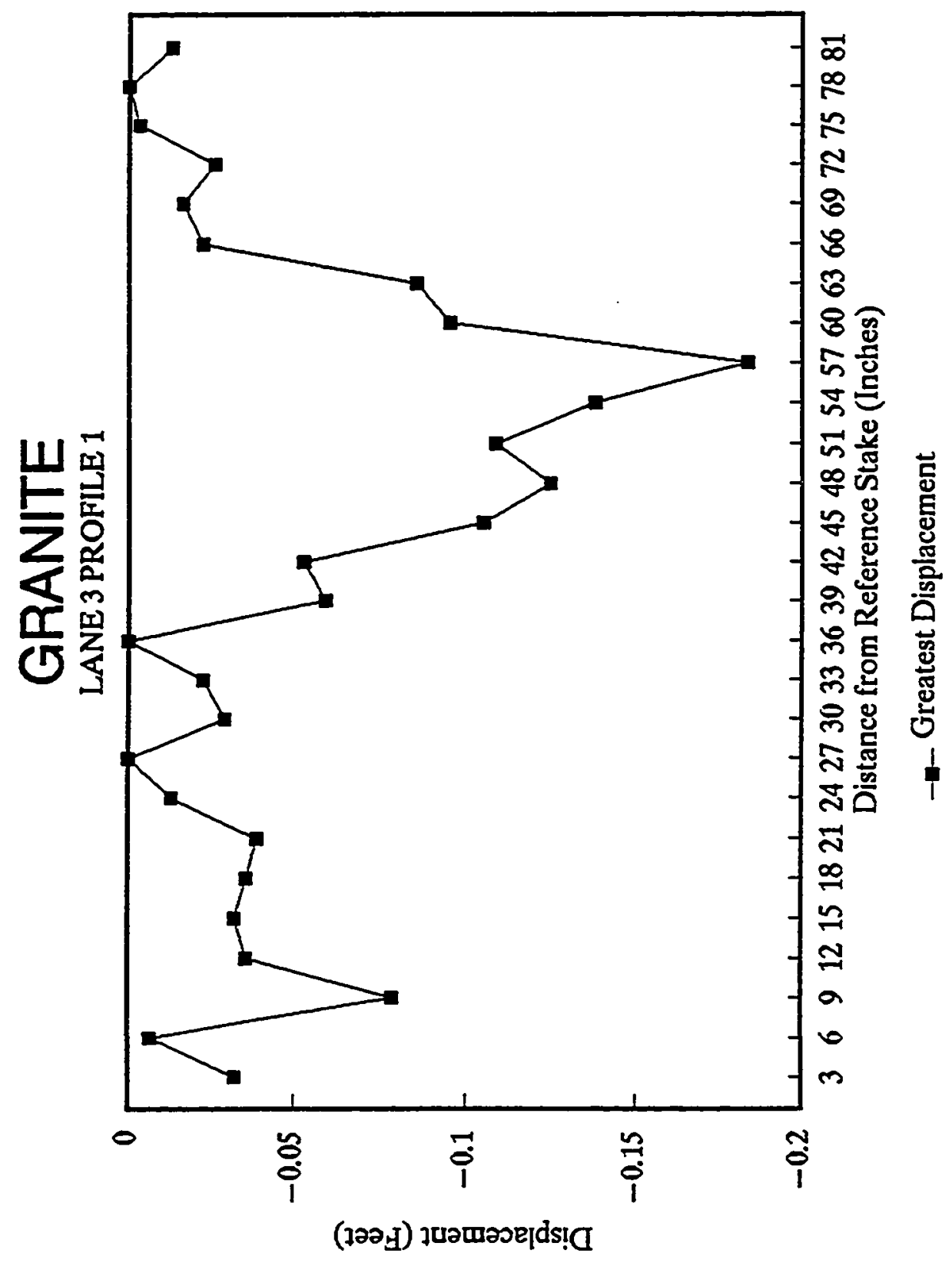




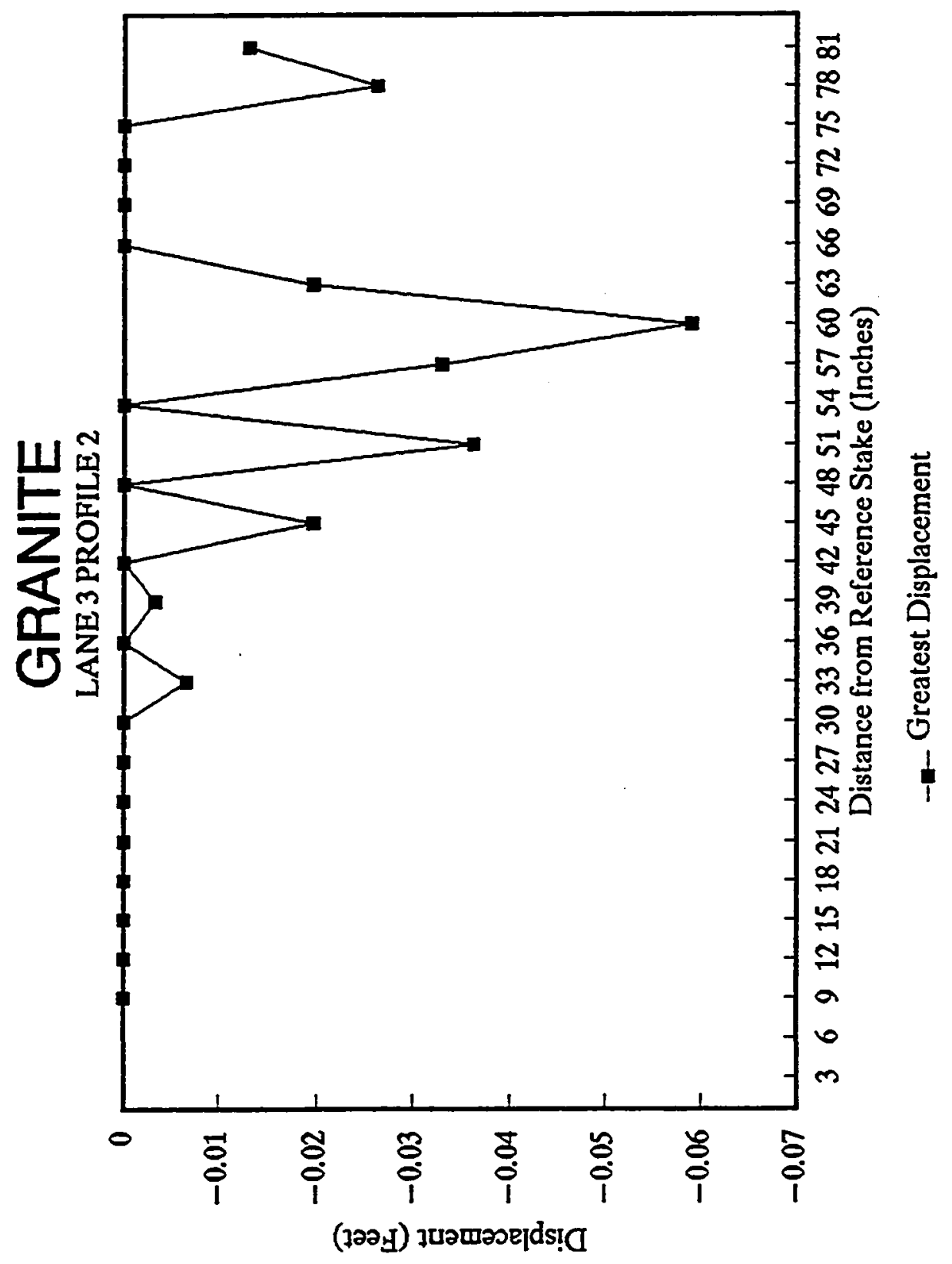




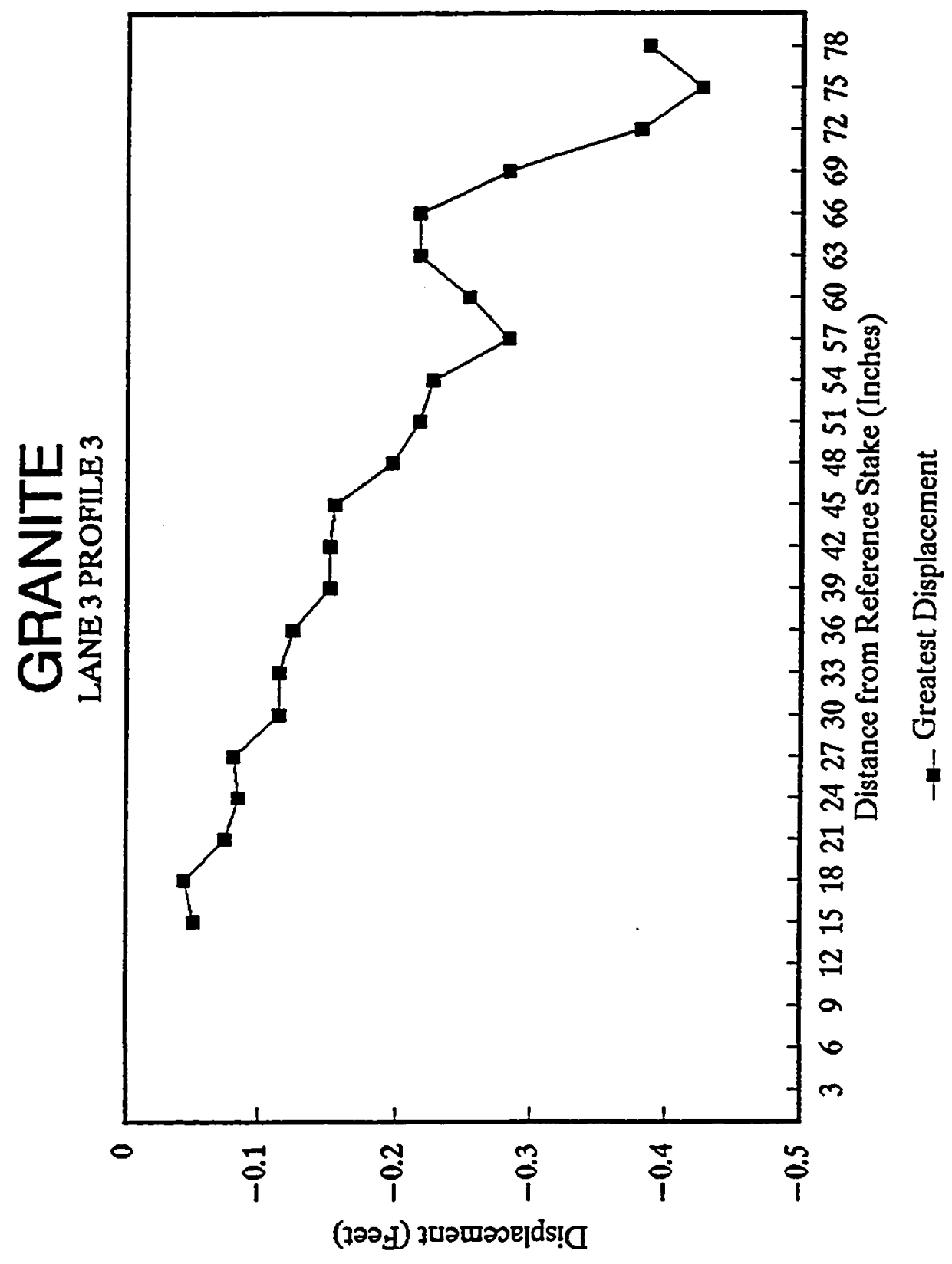




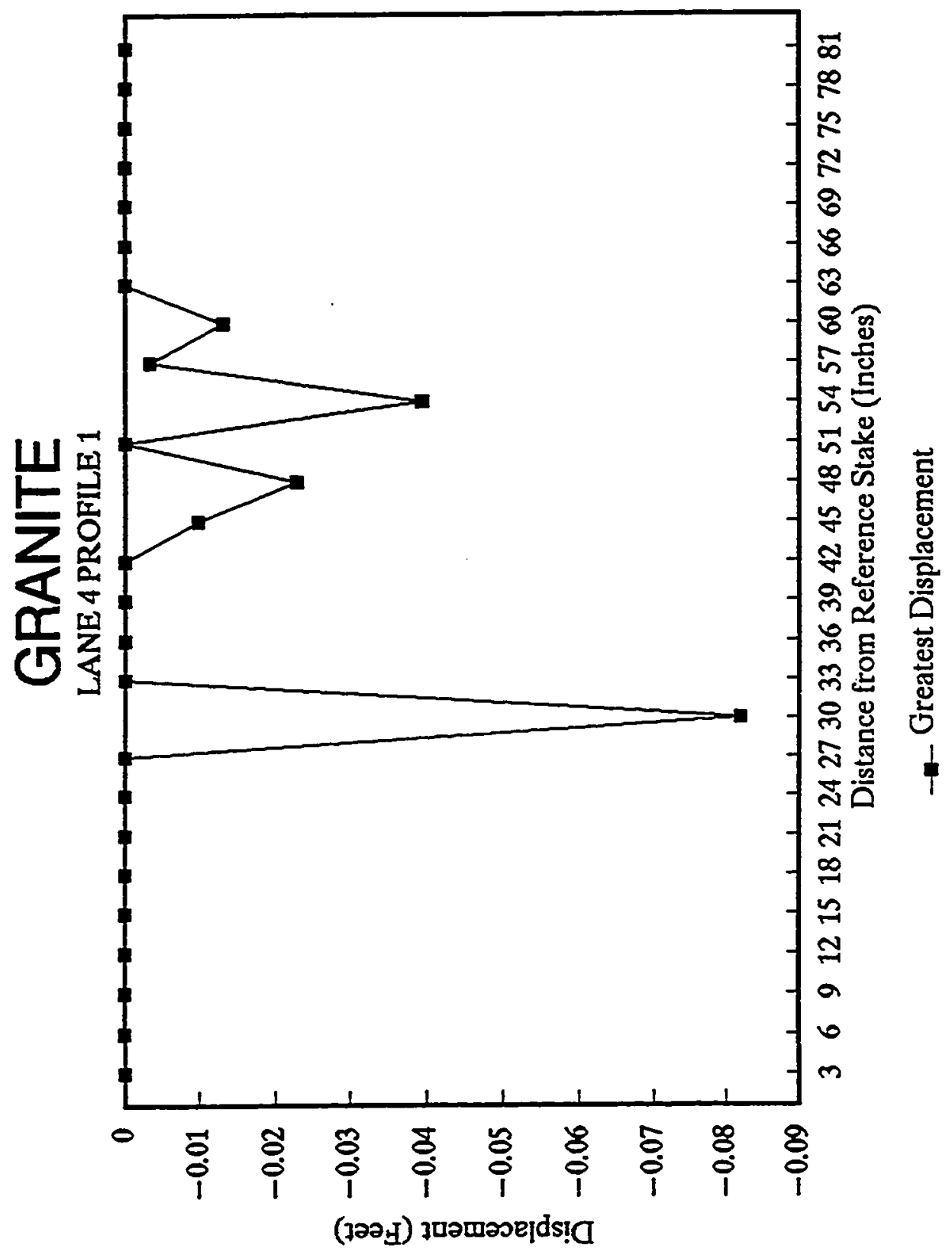




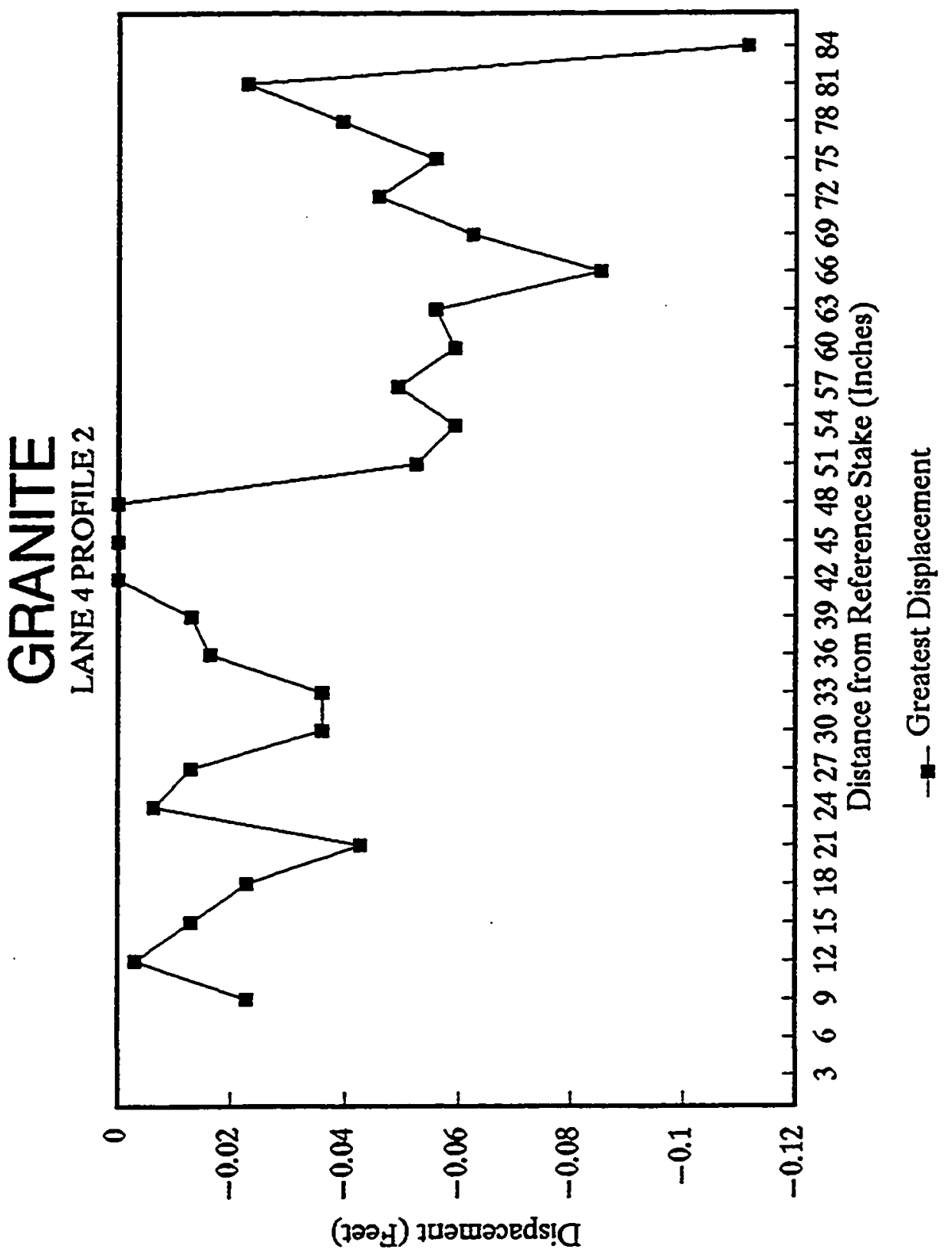




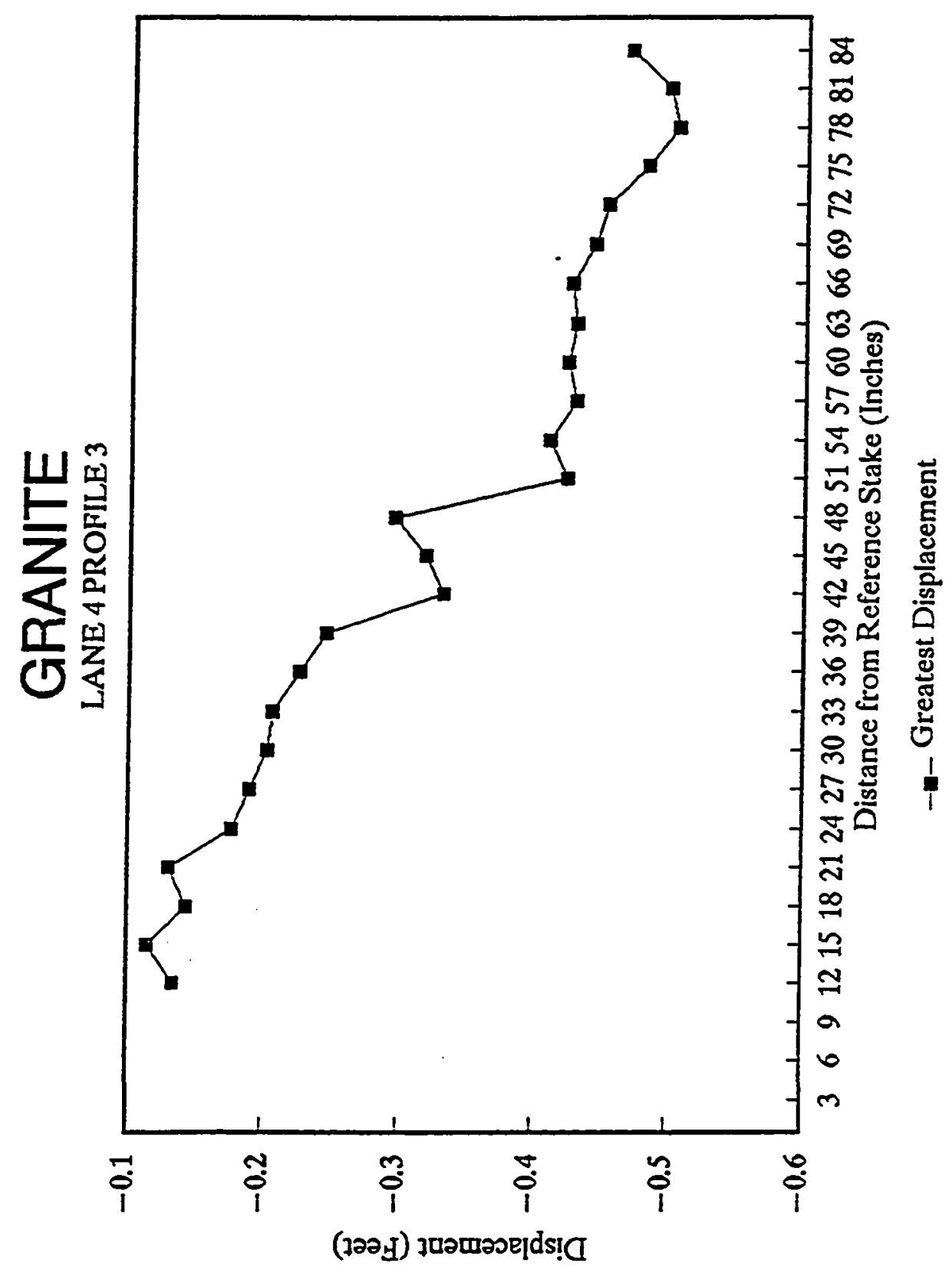

